\title{
COMMENT
}

\section{THE AFTERMATH OF THE RIOT: BALANCING THE BUDGET}

\author{
KENT: \\ Things that love night \\ Love not such nights as these; the wrathful skies \\ Gallow the very wanderers of the dark, \\ And make them keep their caves. Since I was man, \\ Such sheets of fire, such bursts of horrid thunder, \\ Such groans of roaring wind and rain, I never \\ Remember to have heard. Man's nature cannot carry \\ $T h$ affliction nor the fear.
}

People and their property are the victims of riots, and future riots will claim more victims than the riots of the past. Each time, after the destruction, the damage must be repaired; yet the law today is ill-equipped to deal with the aftermath of a riot, as ill-equipped as society will be for many years to deal with its causes. Legislative action is certainly desirable, but by no means is certain to come; most restoration in the next few years will take place within the framework of the law as it is today. It is this framework, and some of the executive and judicial modifications possible within it, that this Comment will explore.

\section{IMMEDIATE RELIEF}

All the states, the District of Columbia and the territories have legislation which makes public funds available for emergency use. ${ }^{1}$

1 Ala. Code tit. 37A, $\$ \$ 19(66)-(90)$ (1959) ; Alaska Stat. $\$ \$ 26.20 .010-.200$ (1961), as amended, Alaska Stat. $\$ 26.20 .145$ (Supp. 1967); ArIz. Rev. Stat. Ann. §\$ 26-301 to -364 (1956), as amended, ARIz. Rev. Stax. ANN. \$26-321 (Supp. 1967), and Ariz. Rev. Stat. ANN. \$35-192 (Supp. 1967); ARK. Stat. ANN. $\$ \S 11-1901$ to -1933 (Supp. 1967) ; CALIF. MIL. \& VET. $\$ \$ 1500-1600$ (West 1955), as amended, CalIF. Mrr. \& Vet. \$\$ 1500-91 (West Supp. 1967) ; Colo. Rev. Stat. AnN. \$\$ 3-17-1 to -18 (1963), as annended, Colo. Rev. Stat. ANn. § 3-17-5 (Supp. 1967); Conn. Gen. Stat. Ann. \$\$ 28-1 to -22 (1960), as amended, Conn. Gen. Stat. Ann. $\$ \S 28-1$ to -19 (Supp. 1966); DEL. CODE ANN. \$\$ 7-5701 to -5704 (Supp. 1966); D.C. Code 1 App. Reorg. Ord. No. 49 (1967) ; Fra. Stat. ANN. \$\$252.02-.221 (Supp. 1966) ; GA. Cone ANN. \$\$ 86-1801 to -1822 (1963), as amended, GA. Cone ANN. $\$ \$ 86-1805$ to -1809 (Supp. 1967) ; HAWAII REV. LAws $\$ \$ 358-1$ to -11 (1955), as amended, HawaIt Rev. Laws $\$ \$ 358-12,359$ (Supp. 1965) ; IDAHo CoDE ANN. $\$ \$ 46-1001$ to -1012 (Supp. 1967) ; IlL. ANN. STAT. ch. 127, \$\$269-288.1 (Smith-Hurd 1967); Ind. ANN. STAT. \$\$ 45-1501 to -1565 (1965); Iowa CODE ANN. \$\$29C.1-.16 (1967); Kan. Stat. ANN. \$ $\$ 48-903$ to -922 (1964), as amended, KAN. Stat. ANN. $\$ \$ 48-903$ to -907 (Supp. 1967); Ky. REv. Stat. $\$ \$ 39.400-.432$ (1963); LA. Rev. Stat. Ann. \$\$29-601 to -617 (1963); Me Rev. Stat. Ann. tit. 25, §\$301-23 (1964), as amended, ME Rev. STAT. ANN. tit. 25, \$\$ 303-12 (Supp. 1967); MD. ANN. CODE art 16A, \$\$1-37 (1966); MASS. ANN. LAwS ch. 23, §9H, ch. 40, §19 (1961); Mrch. Stat. ANN. $\$ \$ 4.823(61)$ - (73) (1961), as amended, Mich. STat. AnN. $\$ \$ 4.823(61), 4.823(63)$ (Supp. 1968); Mrnn. Stat. AnN. $\$ \$ 12.01-.57$ (1967); Miss. Code ANN. \$\$ 8610-01 to -31 (1956), as amended, Mrss. CODE ANN. \$\$ 8610-02 to -18 (Supp. 1966); Mo. AnN. Stat. \$\$ 44.010-.130 (Supp. 1967) ; MoNt. Rev. Codes 
These "emergency acts" are directed towards recovery and rehabilitation in a general sense. Although temporary food supplies, medicine and shelter may be afforded to individuals, these acts do not displace the need or rationale for governmental liability, which operates in a manner similar to private insurance by giving dollar value for damages sustained by the individual.

Most often these statutes are entitled "Civil Defense" acts, which are of two basic types. (1) Twenty-nine states have statutes of which the Alabama Civil Defense Act is typical: ${ }^{2}$

[T] he term "civil defense" shall mean the preparation for and carrying out of all emergency functions, other than functions for which military forces or other federal agencies are primarily responsible, to prevent, minimize, and repair injury and damage resulting from disasters caused by enemy attack, sabotage, or other hostile action, or by fire, flood, earthquake, or other natural cause.

Ann. \$ $\$ 77-1301$ to -1313 (1947), as amended, Mont. Rev. Codes Ann. \$77-1304 (Supp. 1967) ; Neb. Rev. Stat. \$\$ 81-829.06-.35 (1966); Nev. Rev. Stat. \$\$ 414.010.160 (1957) ' N.H. Rev. Stat. ANN. \$\$107:1-:25 (1964); N.J. Stat. Ann. App. A 9-33 to -57 (1966) ; N.M. STAT. ANN. \$\$11-7-1 to -3 (1966) ; N.Y. EXEC. LAW \$ 10-1a (McKinney Supp. 1967); N.C. GEN. STAt. \$\$ 166-1 to -13 (1964); N.D. CENT. CoDe $\$ \$ 37-17-01$ to -16 (Supp. 1967) ; OHIo REv. CoDE ANN. $\$ \$ 5915.01-.99$ (Page 1953), as amended, OnIo Rev. Code AnN. \$\$ 5915.01-.31 (Page Supp. 1966); OkLA. Stat. ANn. tit. 63, \$\$680-683.21 (Supp. 1967); ORE. Rev. STAT. \$\$401.010-.890 (1953), as amended, ORE. Rev. Stat. \$\$ 401.010-.990 (Supp. 1967); PA. Stat. ANN. tit. 71, $\S 1689.1-101$ (1964), as amended, PA. STAT. ANN. tit 71, $\$ 1689.101-.103$ (Supp. 1966) ; R.I. GEN. LAws ANN. \$\$ 30-15-1 to -38 (1956), as anended, R.I. GEN. LAwS ANN. \$\$ 30-15-4 to -40 (Supp. 1966); S.C. CoDE ANN. $\$ \$ 44-301$ to -308 (1962), as amended, S.C. CoDE ANN. \$ 44-308 (Supp. 1967); S.D. CODE \$\$ 41.01C01-.01C15 (Supp. 1960); Tenn. Code ANn. \$\$7-601 to -630 (Supp. 1967); Tex. Rev. Civ. Stat. ANN. art. 6889-4(1) to -4(12) (1960); UTAB CODE ANN. \$\$63-5-1 to -19 (1959); VT. Stat. AnN. tit. 20, $\$ 1-24$ (1959), as amended, Vt. Stat. ANN. tit. 20, \$§3-29 (Supp. 1967); VA. CODE ANN. \$\$ 44-141 to -146.1 (1953), as amended, VA. CODE ANN. $\$ \$ 44-142.1$ to -145.3 (Supp. 1966) ; WASH. REV. CoDE $\$ \$ 38.52 .010-.920$ (1964), as anended, WASH. REv. Code $\$ \$ 38.52 .010-030$ (Supp. 1967); W. VA. CoDE ANN. $\$ \$ 15-5-1$ to -18 (1966) ; Wrs. Stat. ANN. \$\$22.01-.10 (Supp. 1967); Wxo. STat. ANN. \$\$ 19-99 to -115 (1957), as amended, WYo. STAт. ANN. \$\$19-103 to -112 (Supp. 1965); C.Z. Cone tit. 2, \$235 (1963); GUAM Gov' Cone $\$ \$ 8500-19$ (1961), as amended, GuaM Gov'T Code $\$ 8516.1$ (Supp. 1964); P.R. LAws ANN. tit. 3, §\$ 451-65 (1965), as amended, P.R. LAWs ANN. tit. 3, \$\$ 457-65 (Supp. 1966); V.I. CODE ANN. tit. 23, \$\$ 1101-06 (1962).

2 AlA. COde tit. 37A, $\$ 19(68)$ (1959). See the identical provisions in ARK. STAT. Ann. §11-1918 (Supp. 1967); Conn. Gen. Stat. AnN. \$28-1 (1960); Fla. Stat. ANN. \$252.07, \$252.071 (Supp. 1966) ; HawaIr REv. LaWS \$358-2 (1955); IDAHo Code AnN. \$ 46-1001 (Supp. 1967) ; Ill. Ann. Stat. ch. 127, \$271 (1967); La. Rev. Stat. Ann. \&29-614 (1963) ; Me. Rev. Stat. Ann. tit. 25, \& 303 (Supp. 1967); Md. Ann. Code art. 16A, \& 3 (1966) ; Mrch. Stat. Ann. \$ 4.823(62) (1961); Minn. Stat. Ann. \$12.03 (1967); Miss. Code Ann. \$8610-02 (Supp. 1966); Mo. AnN. Star. \$ 44.010 (Supp. 1967); Neb. Rev. Stat. \& 81-829.08 (1966); Nev. Rev. Stat. $\$ 414.030$ (1957); N.H. Rev. Stat. ANn. \$ $107: 2$ (1964); N.Y. Exec. LAw \$ 10-1a (McKinney Supp. 1967); N.D. CENT. CODE \$37-17-02, \$37-17-16 (Supp. 1967); OKLa. Stat. ANN. tit. 63, \$ 683.3(a) (Supp. 1967) ; Ore. Rev. Stat: \$ 401.030 (Supp. 1967); PA. Stat. ANN. tit. 71, \$1689.2 (1964); S.D. Code $\$ 41.01 C 03$ (Supp. 1960); Tenn. Code Ann. \$ 7-602(a), \$7-602(c) (Supp. 1967); Tex. Rev. Civ. Stat. AnN. art. 6889-4(2) (1960); VT. STAT. ANN. tit. 20, \$2 (1959); WASH. REv. Code $\$ 38.52 .010$ (Supp. 1967); W. VA. COde ANN. \$15-5-2 (1966); Wyo. Stat. ANN. $\$ 19-100$ (1957). 
(2) Eight other states define Civil Defense in almost the same way, except that "fire, flood, earthquake" is followed by "or other cause" instead of "or other natural cause." 3

At the outset, such statutes, although clearly covering fire damage, pose a construction problem by their seeming division of disasters into war disasters and natural disasters: riots cannot be said to clearly fit into either classification. Nonetheless, it is clear that the purpose of the civil defense acts is to provide a legal peg for mobilization of resources when a disaster has reached proportions beyond which selfhelp and local action are ineffective. That the statutes speak explicitly to the origins of a major disaster in war or nature argues no more than that war and natural causes are the most likely devastators. The statutes are not restrictive; they are open-ended. To construe the statutory terms as dividing the disaster universe, excluding domestic hostilities from the spectrum including foreign hostile action and natural domestic disaster, is to do violence to the remedial aim. It would be anomalous to assert that a major riot disaster does not in and of itself fall within "other hostile action" and "other cause" (or "other natural cause"), until and unless the rioters have triggered the statute by becoming arsonists.

The thirteen remaining states present a variety of laws; those of six states and the District of Columbia clearly cover riots, ${ }^{4}$ while the language of the remaining seven statutes ${ }^{5}$ is unclear. In any event, the states through their agencies have been active in giving aid during and following riots; it is in this broad emergency legislation that they find their authority.

In order for this emergency aid to be available, many states require a declaration of emergency by the governor. ${ }^{6}$ Other states do not

3 Artz. Rev. Stat. ANN. \$26-301 (1956); Ga. Code ANn. \$1803 (1963); INd. Ann. Stat. \$ 45-1518 (1965) ; Kan. Stat. Ann. \$ 48-904 (1964); Ky. Rev. Stat. $\$ 39.401$ (1963) ; Mont. Rev. Codes AnN. \$77-1303 (1947); N.J. Stat. Ann. App. A, § 9-34 (1966); S.C. CODE ANN. \$ 44-302 (1962); GUAM Gov'T CODE \$ 8502 (1961).

4 CALIF. MII. \& VET. $\$ 1505$ (West Supp. 1967) ("riots"); D.C. CodE 1 App. Reorg. Ord. No. 49, part II (1967) ("any catastrophe other than enemy attack"); IowA CODE ANN. \$29C.1 (1967) ("Manmade disasters") ; R.I. GEN. LAWS \$ 30-15-14 (1956) ("natural or unnatural causes"); UTAF CODE ANN. \$63-5-8 (1959) ("riots"); VA. CODE ANN. \$44-141 (1963) ("war, grave national peril, or serious natural disaster"); WIs. STAT. ANN. \$22.02(1) (Supp. 1967) ("manmade").

5 Alaska Stat. \$26.20.020(6) (1961) ("enemy attack"); Colo. Rev. Stat. ANN. \$3-17-3 (1963) (natural disasters enumerated); DEL. CoDE ANN. \$5701 (Supp. 1966) (same); MAss. Ans. Laws ch. 23, §9H and ch. 40, §19 (1961) (same) ; N.M. STAT. ANN. \$11-7-1 (1966) (enumerated natural "or other causes"); N.C. GEN. STAT. \$166-2 (1964) ("hostile action, fire, flood, windstorm, or explosion"); OнIо REV. CODE ANN. \$5915.01(c) (1953) ("attack or other disaster"); see C.Z. CoDE tit. $2, \S 235$ (1963) (enumerated natural "or like cause"); P.R. LAws ANN. tit. 3, $\$ 451$ (1965) (enumerated natural or "disaster through force majeure"); V.I. CODE ANN. tit. 23, \$1103(6) (1962) ("enemy attack, emergency, or disaster").

6 Ala. Code tit. 37A, \$19(73) (1959); ArIz. Rev. Stat. AnN. \$35-192 (Supp.

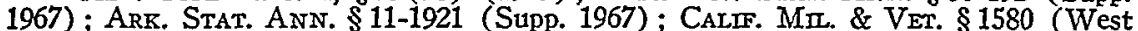
1955 ) Colo. Rev. Stat. Ann. \& 3-17-4 (1963); Conn. Gen. Stat. Ann. \& 2S-9 (1960); D.C. CODE 1 App. Reorg. Ord. No. 49, part II, \$ B (1967) (Board of Commissioners); FLA. STAT. ANN. \$252.07 and \$252.071 (Supp. 1966); ILL. AnN̦, 
expressly provide for such a proclamation, but give the governor general direction and control of all functions provided for under the act. ${ }^{7}$ Under either type of statute, therefore, the determination of when disaster relief shall be given is made by the governor. ${ }^{8}$

The measures available pursuant to activation of the emergency statutes are of broad compass. Typical is Alabama's statute:

These functions include, without limitation, fire-fighting services, police services, medical and health services, rescue, engineering, air raid warning services, communications, radiological, chemical and other special weapons of defense, evacuation of persons from stricken areas, emergency welfare services (civilian war aid), emergency transportation, plant protection, temporary restoration of public utility services, and other functions related to civilian protection, together with all other activities necessary or incidental to the preparation for and carrying out of the foregoing functions. ${ }^{9}$

Those statutes not using this form of provision substitute language permitting the utilization of existing services, facilities and resources of the state. ${ }^{10}$ All the states provide for the acceptance of federal help.

Stat. ch. 127, §275 (Smith-Hurd 1967); LA. Rev. Stat. ANn. \$29-607 (1963); ME Rev. Stat. ANN. tit. 25, \$307 (1964) ; MICH. STat. ANN. \$ 4.823(64) (1961); Mo. Ann. Stat. $\$ 44.100$ (Supp. 1967); Nev. Rev. Stat. \$ 414.070 (1957); N.H. Rev. Stat. ANN. \$107:8 (1964); N.M. Stat. ANN. \$11-7-3 (1966); N.Y. Exec. LAW \$10-1d (McKinney Supp. 1967); N.C. GEN. Stat. \$ 166-6 (1964); N.D. Cent. Code \& 37-17-06 (Supp. 1967); OHIo Rev. Code AnN. \$ 5915.01 (Page 1953); R.I. Gen. Laws Ann. \$30-15-14 (1956); Tenn. Code Ann. \$7-615 (Supp. 1967); Tex. Rev. Civ. Stat. ANn. art. 6889-4(3) (1960); UTAR Code ANn. \$63-5-3 (1959); VT. Stat. ANN. tit. 20, \$9 (Supp. 1967); VA. CODE ANn. \$44142.2 (1963); W. VA. Code ANN. \$15-5-6 (1966); WIs. Stat. ANN. \$22.02(1) (Supp. 1967) ; P.R. LAws ANN. tit. 3, \$ 451 (1965).

7 GA. Code ANN. \$86-1806 (1963); INd. ANN. Stat. \$45-1521 (1965); Ky. Rev. Stat. \$39.408 (1963); Md. Ann. Code art. 16A, \$6 (1966); Mrnn. Stat. ANN. \$12.21 (1967) ; MIss. Code ANN. \$ 8610-06 (Supp. 1966); MoNT. Rev. Codes ANN. \$ 77-1306 (1947); NEB. REv. STAT. \$ 81-829.09 (1966); S.D. CoDE \& 41.01C05 (Supp. 1960); Wase. Rev. Code $\$ 38.52 .050$ (1964); Wyo. Stat. ANn. \$19-102 (1957); GuAM Gov'T CoDE § 8505 (1961).

${ }^{8} \mathrm{~A}$ few states provide for a declaration either by the governor or a concurrent resolution of the state legislature. ALA. CODE tit. 37A, \$19(73) (1959); ARr. STAT. ANN. §11-1922 (Supp. 1967); W. VA. CoDE ANN. \$15-5-6 (1966).

9 ALA. CODE tit. 37A, $\$ 19(68)$ (1959). See the almost identical provisions in Ariz. Rev. Stat. ANN. \$26-301 (1956); Arr. Stat. ANN. \$11-1918 (Supp. 1967); Fla. Stat. AnN. \$252.03 (Supp. 1966); Ga. Code AnN. \$ 86-1803 (1963); Hawain Rev. Laws \$358-2 (1955); ILI. ANN. STAT. ch. 127, \$271 (Smith-Hurd 1967); IND. Ann. Stat. \$ 45-1518 (1965); Ky. Rev. Stat. \$39.401 (1963) ; Me. Rev. Stat. AnN. tit. 25, $\$ 303$ (Supp. 1967); Mrnn. Stat. Ann. \$12.03 (1967); Miss. Code AnN. $\$ 8610-03$ (1956); Mo. ANN. Stat. \$ 44.010 (Supp. 1967) ; Mont. Rev. Codes ANN. $\$ 77-1303$ (1947); Neb. Rev. Stat. \$ 81-829.08 (1966); NEv. Rev. Stat. \$ 414.030 (1957); N.H. Rev. Stat. ANN. \$ $107: 2$ (1964); N.C. 'GEN. Stat. \$166-2 (1964); N.D. Cent. Code \$37-17-02 (Supp. 1967); Ohio Rev. Code ANn. \$ 5915.01 (Page 1953); ORla. STAT. ANN. tit. 63, \$683.3(a) (Supp. 1967); S.D. Code \$ 41.01C03 (Supp. 1960); TenN. Code ANN. \$ 7-601 (Supp. 1967); VT. Stat. ANN. tit. 20, \$2 (1959); Wase. Rev. Code $\$ 38.52 .010$ (Supp. 1967); W. VA. Code ANn. \$15-5-2 (1966); Wyo. Stat. ANn. \$19-100 (1957); Guam Gov't Code §8502 (1961).

10 Caltr. MrL. \& VET. § 1576 (West Supp. 1967); Colo. Rev. Stat. Awn. § 3-17-5 (Supp. 1967) ; Conn. Gen. Stat. Ann. \$28-9 (1960); D.C. Code 1 App. Reorg. Ord. 
A few states create limited emergency funds for use by the state executive. ${ }^{11}$ Most states, however, either are silent on this point or declare that the executive may draw from the general funds allocated to the executive branch.

Similar in form and function to the state aid programs is federal assistance made available in defined emergency situations under the Disaster Relief Act. ${ }^{12}$ The Act defines "major disaster" as

any flood, drought, fire, hurricane, earthquake, storm, or other catastrophe in any part of the United States which, in the determination of the President, is or threatens to be of sufficient severity and magnitude to warrant disaster assistance by the Federal Government to supplement the efforts and available resources of States and local governments in alleviating the damage, hardship, or suffering caused thereby. . . . ${ }^{13}$

No President, however, has ever qualified a riot as a "major disaster" under the Federal Disaster Relief Act.14 Indeed, it was asserted during the summer 1967 riots that the statute has "not in the past been applied to disasters other than those resulting from natural causes," 15 that further there was "some doubt that the law could be used in manmade disaster situations." 16

No. 49, part III, § B (1967); Iowa Code ANN, §29C.8 (1967) ; Kan. Stat. ANN. \$ 48-908 (1964); MD. AnN. Code art. 16A, \$ 10 (1966) ; Mich. Stat. ANn. \$ 4.823(65) (1961); Minn. Stat. ANN. \$ 12.23 (1967); Nev. Rev. Stat. \$ 414.140 (1957); N.Y. ExEc. LAW \$10-1d (McKinney Supp. 1967); R.I. GeN. LAws ANN. § 30-15-14 (1956); TEx. Rev. Crv. Stat. ANN. art. 6889-4 (8) (1960) ; UTAH Cone ANN. \$ 63-5-11 (1959); VT. Stat. ANN. tit. 20, \$9 (Supp. 1967); VA. Code AnN. \$ 44-145.4 (1963); W. Va. Code Ann. \$15-5-13 (1966); Wyo. Stat. Ann. \$19-110 (1957) ; C.Z. Code tit. $2, \$ 235$ (1963). It should also be noted at this point that state statutes may also explicitly include the use of similar municipal services and facilities. See, e.g., ALA. CODE tit. 37A, \& 19(75) (1959).

11 AlA. CoDE tit. 37A, $\S 19(90)$ (1959) $(\$ 250,000$ per emergency); ARIz. Rev. STAt. ANN. \$ 35-192 (Supp. 1967) ( $\$ 50,000$ per emergency without consent of disaster board; $\$ 750,000$ per year with consent); N.M. STAT. ANN. $\$ 11-7-2(1966)(\$ 200,000)$.

1242 U.S.C. $\$ 1855$ (1964).

1342 U.S.C. \$1855a (1964).

${ }^{14}$ The Wall Strect Journal, July 28, 1964, at 1, col. 3. On July 28, 1967, Governor Romney requested federal assistance in the aftermath of the Detroit, Michigan, riot.

[W]e have been advised by Gov. Farris Bryant (of the Office of Emergency Planning) and Deputy Attorney General Christopher that the provisions of the Federal Disaster Assistance Act have not in the past been applied to disasters other than those resulting from natural causes.

N.Y. Times, July 28, 1967, at 11, col. 1 (city ed.). The Uiniversity of Pennsylvania Law Reviez, in a telephone conversation with Mr. Charles $\mathrm{H}$. Beal, Office of Emergency Planning, on January 9, 1968, confirmed that Governor Romney's request was never filled. It is the position of the Office of Emergency Planning that no riot could ever occasion the granting of assistance under the Act. Letter from Robert Y. Phillips, Director, Emergency Operations Office, to University of Pemisylvania Law Review, March 8, 1968, on file in Biddle Law Library, Philadelphia, Penna.

15 N.Y. Times, July 28,1967 , at 11, col. 1 (city ed.).

16 N.Y. Times, July 28, 1967, at 11, col. 3 (city ed.). 
The Act, however, does not address itself to the causes of major disasters. Rather, it lists events which are classed as major disasters once they reach the proportions warranting, "in the determination of the President," disaster assistance. Fire is one of the enumerated contingencies. There is no warrant for the argument either in the language of the statute or in the legislative history that only conflagrations started, for example, by lightning, a "natural cause," may come within the contemplation of the Act, and man-made fires be excluded. Nor can it be argued that it is the origin of the fire, rather than the fact of its existence, which constitutes it a "natural disaster" (if that term is used to characterize the listed catastrophes) ${ }^{17}$ The federal government responded with federal disaster assistance to the wide-

If Apparently, Governor Romney conceived of the issue of whether Detroit should receive assistance as dependent on proper construction of the phrase "or other catastrophe." He stated :

Last week part of the Detroit metropolitan area was declared a disaster area following a five-inch rainfall. It simply does not make sense not to commit Federal assistance to the City of Detroit in view of what has happened in recent days.

We urgently request that this policy be re-evaluated in view of the fact that the statute covers natural disasters "or other catastrophe which in the determination of the President" warrants special Federal assistance and that such assistance be approved for the City of Detroit.

N.Y. Times, July 28,1967 , at 11 , col. 1 (city ed.).

Arguments to support the position that only natural disasters are within the scope of the law, other than citing the practice under the Act, begin with the language of the statute, which makes "or other catastrophe" susceptible to limitation by ejusdem generis. See Note, Compensation for Victims of Urban Riots, 68 CoLUM. L. REv. $57,82-83$ (1968). Further, most of the House debate was concerned with floods and other natural disasters, but not riots. 96 CoNG. REc. 11896-915 (1950). See to the same effect the Senate debates. Id. at 15095-96. And the law was said to be a substitute for the practice of individually legislating for each disaster. The list of past Congressional acts included only natural disasters. Id. at 11900-02. Finally, the Federal Disaster Relief Act updated "An Act to make surplus property available for the alleviation of damage caused by flood or other catastrophe." 42 U.S.C. $\$ \$ 1851-54$ (1947).

Most probably, however, whether riot should be covered was not in issue at the time. The Korean War was in progress when the law was passed, and the focus of discussion on what "or other catastrophe" meant was directed, logically enough, to whether catastrophes caused by war were included. Thus, Representative Byrnes of Wisconsin, an opponent of the bill, stated on the floor of the House that "the bill does not even mention disaster as the result of enemy action." 96 CoNG. REc. 11908 (1950). On the other hand, S. REP. No. 2571, 81st Cong., 2d Sess. 1 (1950), quoting H.R. ReP. No. 2727 , 81st Cong., 2 d Sess. 2 (1950), stated:

The purpose of the bill is to provide for an orderly and continuing method of rendering assistance to the States and local governments in alleviating suffering and damage resulting from a major peacetime disaster.

It is not clear, however, whether even the war/non-war issue was ever resolved.

In the House, the following statements were made:

Mr. Hagen. We have two suggested and desirable general programs. The one is immediate aid for Minnesota and North Dakota, and the broad general program for the whole country where emergencies of any kind, whether bombing or flood, hurricane or cyclone, may hit or strike a community. . . .

96 CoNG. REC. 11904 (1950) (emphasis added).

$M r$. Hagen. This bill also covers bombing of cities like New York and Washington. If those cities were bombed a bill of this kind would cover a situation of that nature?

$M r . H$. Carl Anderson. Why, certainly; in my opinion it would cover any calamity that our people suffer.

Id. at 11909 . 
spread forest fires of August, 1967, without raising the question of whether it was started by a "who" or a "what." 18

The preamble to the Disaster Relief Act states as the purpose of the legislation

assistance by the Federal Government to the States and local governments in carrying out their responsibilities to alleviate suffering and damage resulting from major disasters, to repair essential public facilities in major disasters, and to foster the development of such State and local organization and plans to cope with major disasters as may be necessary. ${ }^{19}$

These objectives are not disserved by employing the Act in the riot context. Certainly, the major part of human "suffering" in the riots resulted from dislocation caused by fire; "damage" included "entire blocks . . . leveled by fire." 20 That violence, looting and other destruction accompanied the blaze does not negate the disaster proportions of the fire and the statute's permissive mandate "to alleviate suffering and damage." Culpability is irrelevant to the Relief Act's functions. ${ }^{21}$

The statute, then, was available for Presidential designation ${ }^{22}$ of a riot as a major disaster and it therefore warrants inquiry into the specifics of its operation. However, if it is to be used effectively in the future to assist the states-note that other emergency legislation is tied to the finding of a "major disaster" 23 - the political sensitivity of transmuting "riot" into "fire" must be removed by clear Congressional language mandating ${ }^{24}$ aid under the Act to riot-torn areas.

18 See, e.g., N.Y. Times, Aug. 31, 1967, at 26, col. 1.

1942 U.S.C. §1855a (1964).

20 N.Y. Times, July 28, 1967, at 11, col. 1 (city ed.).

21 The N.Y. Times reported that officials "were said to be weighing the question of whether to 'reward' lawlessness with special Federal grants" under the Act. Id. Again, one might note at this point that federal disaster relief is always activated without question of cause in the event of a forest fire. See text accompanying note 18 supra.

22 In a telephone conversation with Mr. Sol Lindenbaum, Executive Assistant to the Attorney General, formerly of the Office of Legal Counsel, on February 5, 1968, the University of Pennsylvanio Law Review was advised that no legal memorandum, available for public perusal, construing the applicability of the Act to riots, was issued by the Department of Justice during the summer of 1967 or, apparently, at any time prior or subsequent thereto.

23 See text accompanying notes 36-43 infra. The almost complete dependence of other present major statutory relief measures on the Disaster Relief Act is in itself a persuasive argument that the Act covers all domestic disasters which reach major proportions.

24 In the debates on the present Act, Senator McClellan answered affirmatively the question whether he thought the law "would apply to whatever disaster the President might be pleased to have it apply." 96 CoNG. REC. 15096 (1950).

Proposed Congressional action would remedy the defect by clear amendatory language expressly including riots under the Act, see S. 2209, 90th Cong., 1st Sess. (1967) ; H.R. 11891, 90th Cong., 1st Sess. (1967); or through separate legislation for emergency relief to riot areas. See H.R. 12096, 90th Cong., 1st Sess. (1967), and S. 2258, 90th Cong., 1st Sess. (1967). 
The Office of Emergency Planning (OEP) administers disaster relief under the Act. ${ }^{25}$ The procedure which a state must follow to qualify for this federal aid is specified in Executive Order 10,737.26 The first conditions require the state and local government to demonstrate need of assistance and that they are spending a reasonable amount of money themselves. ${ }^{27}$ The request must be directed by the governor to the Regional Director of the OEP. ${ }^{28}$ The Regional Director then sends the request, along with his own recommendation, to the Director of the OEP, ${ }^{29}$ who forwards it with further comment to the President. ${ }^{30}$ At this point, the President determines ${ }^{31}$ whether a "major disaster" within the meaning of the Act exists. ${ }^{32}$ Federal aid is made available under an agreement between the state Governor and the Director of the OEP, ${ }^{33}$ which must include a term providing for the use of a reasonable amount of state and local funds. The President, who is authorized without further act of Congress to appropriate a total sum of $\$ 5,000,000,{ }^{34}$ will then allocate the necessary federal funds to the Director.

25 Exec. Order No. 10,427, 3 C.F.R. 925 (1949-53 Comp.), as anended, Exec. Order No. 11,051, 3 C.F.R. 635 (1959-63 Comp.), 42 U.S.C. \$ 1855 d (1964).

26 Exec. Order No. 10,737, 3 C.F.R. 395 (1954-58 Comp.), as amended, Exec. Order No. 11,051, 3 C.F.R. 635 (1959-63 Comp.), 42 U.S.C. \$1855d (1964).

27 Exec. Order No. 10,737, sispra note $26, \$ 1$.

28 Id. $\$ 2(a)$. The governor's request must include an estimate of damage and total funds, personnel, equipment and material needed; a statement of action taken (or recommended to be taken) by the state or local government; an estimate of state and local funds available for disaster relief; and the extent and nature of federal help needed.

$29 I d . \S 2(\mathrm{~b})$.

30 Id. $\$ 2(\mathrm{c})$.

31 Id. $\S 3(\mathrm{~d})$.

32 Detailed consideration of what factors should enter into the "determination of the President" of whether riot damage has caused a "major disaster" is beyond the scope of this article. Certainly, the President must assess the "severity and magnitude" of the riot damage, much as in non-riot fire disasters.

The Senate debate on the bill authoritatively indicated that a major disaster need not be "national" in scope, and might affect only one city. The President should evaluate the disaster in terms of its local impact rather than on any absolute scale of severity; only emergencies are covered, and then only when the governors find themselves unable, with State and local legislation and resources, to cope with the damage which has been sustained. That is, "[ $t]$ he purpose of the bill is to meet emergency needs, and to meet a situation which the local people cannot meet except at the cost of great suffering and hardship." 96 CoNG. REC. 15097-98 (1950).

Whether other factors are proper, such as "whether to risk a precedent under which many other cities [other than Detroit] would seek similar aid," N.Y. Times, July 28, 1967, at 11, col. 3 , may be another matter. Nonetheless, the fact that, for the purposes of the Small Business Administration, Newark and Detroit were determined to be disasters, see note 41 infra, and not other cities, shows that standards do exist and can be applied for differentiating among riots.

33 Exec. Order No. 10,737, supra note 26, \$2 (e) (1).

3442 U.S.C. $\$ 1855 \mathrm{~g}$ (1964). Section $1855 \mathrm{~g}$ specifies an appropriation to the President of a sum not exceeding $\$ 5$ million to carry out the purposes of the Disaster Relief Act. In reality, however, the President asks for a basic appropriation each year (recently ranging from about $\$ 15$ million to $\$ 25$ million last year). This sum, not the $\$ 5$ million, is the basic amount which is available for disaster relief without further act of Congress. Also supplemental appropriations are often requested and usually granted.

In calculating the yearly amount of federal aid granted, direct funding to the states must always be included. However, by $\S 1855 \mathrm{~b}$, the federal agencies can utilize 
The types of assistance enumerated include equipment, supplies, personnel and other resources; food, medicine or other comestibles; protective or other work essential for the preservation of life and property; any help needed in clearing debris and wreckage and in making emergency repairs to and replacement of damaged public facilities; temporary housing; and contributions to State and local governments for purposes stated in the statute..$^{35}$

Additional help can come from the federal government in the form of urban renewal assistance under 42 U.S.C. section $1462 .{ }^{36}$ The special provisions thereof clearly allow financial aid for renewal projects to be extended more quickly than usual. This statute, however, is tied to a finding of a "major disaster" under 42 U.S.C. section $1855,{ }^{37}$ the Disaster Relief Act. Federal loans are available under 50 U.S.C. section 2092 to aid in rebuilding facilities needed for national defense that are destroyed or damaged by a major disaster. This, too, is keyed to 42 U.S.C. section $1855^{38}$ The few sources of

or lend equipment, supplies, facilities, personnel and other resources for disaster relief with or without compensation, and, therefore, with or without accounting against the basic appropriation. Where federal personnel, such as engineers, are sent to supplement the efforts of state personnel, only extra-normal out-of-pocket costs, such as transportation and overtime, are reckoned against disaster relief appropriations, although the cost of extra personnel is expensed against the fund. Telephone conversation with Mr. James P. Dokken, Disaster Assistance Office, Office of Emergency Planning, February 12, 1968.

Section $1855 \mathrm{~g}$ requires the President to submit to Congress at the beginning of each regular session a full report of amounts spent for disaster assistance. The reports however give only a general breakdown of funds allocated per disaster. See, e.g., H.R. Doc. No. 249, 88th Cong., 2d Sess. 3 (1964) (report of President on 1963 allocations).

3542 U.S.C. $\$ 1855 b$ (1964).

3642 U.S.C. $\$ 1462$ (1964) :

Where the local governing body certifies, and the Administrator finds, that an urban area is in need of redevelopment or rehabilitation as a result of . . . catastrophe which the President, pursuant to section $1855 \mathrm{a}$ (a) of this title, has determined to be a major disaster, the Administrator is authorized to extend financial assistance under this subchapter for an urban renewal project with respect to such area without regard to the following:

(1) the "workable program" requirement . . . ; (2) the requirements . . [ [of conformity to a general plan of the locality] ...; (3) the "relocation" requirements . . . ; (4) the "public hearing" requirement ...; (6) the requirements ... [that the neighborhood

be of a] predominantly residential character....

37 This is not to say that without the "major disaster" determination, the Department of Housing and Urban Development (HUD) has not been active in cities after riots have occurred. Much informal assistance was extended to these cities in quickly applying for and receiving an infusion of federal aid through the normal channels. For example, HUD teams were sent into Cleveland, Watts, Detroit and Newark to investigate the problems and propose programs to correct them; and federal aid often quickly follows the suggestions of such teams. Telephone conversation with $\mathrm{Mr}$. Arthur J. Gang, Deputy Associate General Counsel, Department of Housing and Urban Development, by the University of Pennsylvania Law Review, January 9, 1968. 38 Further new provisions keyed to 42 U.S.C. $\$ 1855$ (1964) are the following: 42 U.S.C. $\$ 1855 \mathrm{bb}$ (b) (Supp. II, 1965-66) : "The Secretary of Housing and Urban Development is authorized to refinance any note or other obligation held by him in connection with any loan made by the Department . . . where he finds such refinancing necessary because of the loss, destruction or damage 
major federal aid (other than the Red Cross ${ }^{39}$ ) not keyed to section $1855^{40}$ are: (1) the granting of disaster loans by the Small Business Administration; ${ }^{41}$ (2) the insuring of mortgages by the Federal Housing Administration for dwellings in riot areas; ${ }^{42}$ and apparently

to property or facilities securing such obligations as a result of a major disaster."

42 U.S.C. § 1855dd (Supp. II, 1965-66) : "Priority to applications for public facility and public housing assistance in major disaster areas."

42 U.S.C. \$ 1855 ee (Supp. II, 1965-66) : this section provides for up to $50 \%$ reimbursement of costs for reconstruction of public facilities damaged or destroyed by a major disaster.

42 U.S.C. \$1855gg (Supp. II, 1965-66) : "Extension of time to leaseholders, etc., of public lands in disaster areas."

39 Purposes of corporation . .

Fifth. And to continue and carry on a system of national and international relief in time of peace and apply the same in mitigating the sufferings caused by pestilence, famine, fire, floods, and other great national calamities, and to devise and carry on measures for preventing the same.

36 U.S.C. § 3 (1964).

40 Non-emergency relief in the form of an ordinary recovery in tort against the federal government for damage caused by military personnel is, of course, independent of $\$ 1855$. Some of the problems involved are explored in Note, Compensation for Victims of Urban Riots, 68 Colum. L. Rev. 57, 79-81 (1968) ; Note, National Guardsmen and Tort Liability, 42 NOTRE DaMe Law. 365 (1966).

4113 C.F.R. \$120.3 (1967) :

(a) Financial assistance for disaster relief will be considered on an individual basis in the light of circumstances of the applicant and of the particular disaster or business displacement. . . . Financial assistance may be extended:

(1) To rehabilitate or replace property damaged or lost-as a result of disasters declared by SBA ... (Physical-Loss Disaster Assistance) ;

But see 13 C.F.R. §120.3(a) (2) (1967) :

To a small-business concern located in an area declared to be a major disaster area by the President or declared to be a natural disaster area by the Secretary of Agriculture or his designee, if SBA determines that the concern has suffered substantial economic injury as a result of such disaster (Sub-

(Emphasis added.) stantial Economic Injury Assistance); . . . .

Compare with the above two sections the following:

Mr. Johnson ordered the Small Business Administration to make available long-term, low-interest loans to home owners and small-business men [sic] whose property was damaged in the Detroit violence.

N.Y. Times, July 30, 1967, at 1, col. 1 (emphasis added).

Mr. Vance said the President had ordered the Administrator of the Small Business Administration to declare the riot-torn section of the city as "areas that have been hit by disaster and therefore eligible for appropriate assistance to home owners and businessmen under the Small Business Act." This will make available three per cent loans for up to thirty years.

Id. at 52, col. 1.

On July 29, 1967, the SBA declared Detroit "Disaster Loan Area 631" and declared Newark, New Jersey "Disaster Loan Area 632." That is, those areas were determined to be a catastrophe within the purview of the SBA. The declarations, respectively F.R. Doc. 67-9153 and F.R. Doc. 67-9154, were filed on August 4, 1967, and can be found at 32 Fed. Reg. 11403-04 (August 5, 1967).

4212 U.S.C. $\$ 1709$ (1) (Supp. II, 1965-66) :

Areas affected by civil disorders. The Secretary is authorized to insure under this section any mortgage meeting the requirements of this section, other than the requirement in subsection (c) of this section relating to economic soundness, if he determines that (1) the dwelling covered by the 
(3) the providing of agricultural commodities for needy persons in riot areas. ${ }^{43}$

\section{Restitution : by suit}

Absent statutory authority, individuals have been unable to sue municipalities or states for personal injury or property damage caused by mob violence. ${ }^{44}$ As the Supreme Court stated in Louisiana ex rel. Folsom v. New Orleans, indemnification for riot damage

is simply a measure of legislative policy, . . . and subject, like all other measures of policy, to any change the legislature may see fit to make, either in the extent of the liability or in the means of its enforcement. ${ }^{45}$

mortgage is situated in an area in which rioting or other civil disorders have occurred or are threatened, (2) as a result of such actual or threatened rioting or other disorders the property with respect to which the mortgage is executed cannot meet the normal requirements with respect to economic soundness, and (3) such property is an acceptable risk giving due consideration to the need for adequate housing for families of low and moderate income in such area.

This section has at least been applied to Newark and Detroit. See N.Y. Times, Aug. 3, 1967, at 17, col. 2.

437 U.S.C. $\$ 1431$ (1964) :

[T]he Commodity Credit Corporation is authorized, on such terms and under such regulations as the Secretary of Agriculture may deem in the public interest: . . . (3) in the case of food commodities to donate such commodities . . . to such State, Federal, or private agency or agencies as may be designated by the proper State or Federal authority and approved by the Secretary, for use in the United States . . . in the assistance of needy persons, and in charitable institutions, including hospitals, to the extent that needy persons are served ....

7 U.S.C. §612c (1964) (surplus removal program) :

Such sums shall be maintained in a separate fund and shall be used by the Secretary of Agriculture only to . . . (2) encourage the domestic consumption of such commodities or products by diverting them, by the payment of benefits or indemnities or by other means, from the normal channels of trade and commerce or by increasing their utilization through benefits, indemnities, donations or by other means, among persons in low income groups as determined by the Secretary of Agriculture . . .

Use of these two sections for distribution of commodities to the victims of manmade disasters as well as natural disasters is provided for by the Department of Agriculture in ConsuMer and Marketing SERV., U.S. DEP'T OF AGRiculture, PA-667, Food Donation Programs (June 1965) ; Consumer and Marketing Serv., U.S. Dep'T of Agriculture, PA-557, Donated Foods for Disasters-A Guide for State and Local Officials (July 1965); $\$ \$ 250.1,250.3,31$ Fed. Reg. 14297-98 (November 5, 1966).

Programs of food donation under both these sections were extended by the Department of Agriculture to give assistance to the cities of Detroit and Newark in 1967. The assistance was administered through local organizations in these cities. Telephone conversation with Mr. Jacob R. Idol of the Consumer and Marketing Service of the Department of Agriculture, by the University of Pennsylvania Law Review, January 9, 1968.

44 Sturges v. City of Chicago, 222 U.S. 313 (1911) ; Louisiana ex rel. Folsom v. City of New Orleans, 109 U.S. 285 (1883); City of New Orleans v. Abbagnato, 62 F. 240 (5th Cir. 1894); Gianfortone v. City of New Orleans, 61 F. 64 (C.C.E.D. La. 1894).

45109 U.S. 285,288 (1883). 
The traditional bar to a non-statutory recovery has been the doctrine of sovereign immunity, ${ }^{46}$ whose historic rationales are that the sovereign "can do no wrong," 47 and that public funds should not be diverted from "public" uses to the payment of private damage claims. ${ }^{48}$ In fact, many courts have begun to recognize the inequity and artificiality in protecting the government from suit and, therefore, have repudiated sovereign immunity, ${ }^{49}$ explicitly rejecting both of the rationales in the process. As to governmental infallibility, the Michigan Supreme Court has "eliminate[d] from the case law of Michigan an ancient rule inherited from the days of absolute monarchy which has been productive of great injustice in our courts." 50 The "public funds" argument likewise was rejected by the Supreme Court of Illinois, which allowed recovery against a school district despite the claim that such a recovery would divert and deplete the funds of the school district. ${ }^{51}$

Where the doctrine of sovereign immunity has been overturned, ${ }^{52}$ some commentators have argued that a common law negligence suit for riot damage should lie against municipalities. ${ }^{53}$ Whether this argu-

46 See City of New Orleans v. Abbagnato, 62 F. 240 (5th Cir. 1894); Gianfortone v. City of New Orleans, 61 F. 64 (C.C.E.D. La. 1894); Goldman v. Forcier, 68 R.I. 291,27 A.2d 340 (1942) (municipality has immunity as arm of state).

47 W. Prosser, Torts 996 (3d ed. 1964). 3 W. Holdsworth, History of the ENGLISE LAW 463-69 (1942 ed.) indicates that this rationale was first applied to a subdivision of the state in Russell v. Men of Devon, 2 T.R. 667, 100 Eng. Rep. 359 (1788).

48 E.g., Leviton v. Board of Educ., 374 Ill. 594, 30 N.E.2d 497 (1940) ; Thomas v. Broadlands Community School Dist., 348 I11. App. 567,109 N.E.2d 636 '(1952).

49 Stone v. Arizona Highway Comm'n, 93 Ariz. 384, 381 P.2d 107 (1963) ; Muskopf v. Corning Hospital Dist., 55 Cal. 2d 211, 359 P.2d 457 (1961); Hargrove v. Town of Cocoa Beach, 96 So. $2 d 130$ (Fla. 1957); Haney v. City of Lexington, 386 S.W.2d 738 (Ky. Ct. App. 1964); Molitor v. Kaneland Community Unit Dist. No. 302, 18 Ill. 2d 11, 163 N.E.2d 89 (1959); Williams v. Detroit, 364 Mich. 231, 111 N.W.2d 1 (1961); Spanel v. Mounds View School Dist. No. 621, 264 Minn. 279, 118 N.W.2d 795 (1962) ; Holytz v. City of Milwaukee, 17 Wis. 2d 26, 115 N.W.2d 618 (1962).

50 Williams v. Detroit, 364 Mich. 231, 250, 11 N.W.2d 1, 20 (1961) (opinion of Edwards, J., concurring in the abrogation of sovereign immunity).

51 Molitor v. Kaneland Community Unit Dist. No. 302, 18 I11. 2d 11, 163 N.E.2d

89 (1959). The claim proved correct. See note 67 infra.

52 Any argument which requires the absence of sovereign immunity as its first premise necessitates a careful research of the local law. It is doubtful that there is any jurisdiction in which sovereign immunity has been completely abrogated for all levels or for all departments of government. The law varies greatly from jurisdiction to jurisdiction and probably is not structured similarly in any two states. Immunity may be grounded in state constitutions, legislation or common law. Common law immunity may be judicially abrogated and selectively reinstated by the legislature. Legislation allowing suit may distinguish between municipal and state levels of government. Furthermore courts may construe the abrogating statutes narrowly. See generally Leflar \& Kantrowitz, Tort Liability of the States, 29 N.Y.U.L. REV. 1363 (1954), for an exhaustive treatment of the law then obtaining. There are many current law review pieces which try to work out the impact of new cases or statutes on the entire body of law in that state.

53 See Jaffe \& Dubin, Trends in Municipal Liability: Riot Damages, INs. L.J. 282 (May, 1967); Sengstock, Mob Action: Who Shall Pay the Price?, 44 J. URBAN LAw 407 (1967); cf. Comment, Municipal Liability for Negligent Failure to Protect Informer: The "Schuster" Case, 59 Colum. L. REv. 487, 492, 502-03 (1959). 
ment can prevail, however, depends upon the character of the state's duty to protect an individual from riot damage.

A succession of English statutes ${ }^{54}$ imposed a duty upon the immediate community to compensate victims of mob violence. The duty so declared could have been rooted in an underlying common law obligation $^{55}$ or, if initially statutory, could have become part of American common law under the reception statutes; alternatively, it could have been a more amorphous moral or societal duty deriving from the social compact. If the latter, then it would seem that, under normal theories of tort recovery, the individual could not sue on the duty without enabling legislation. The government's obligation would run to the general public, not to specific individuals within the community. It would be a political, not legal duty and, hence, not enforceable at law..$^{58}$

It should be noted that the felt need for a similar legislative solution in nineteenth century America ${ }^{57}$ may be traceable entirely to the need for statutory waiver of sovereign immunity, rather than any inherent incapacity of the common law. Nevertheless, the rationales that have been put forth for those statutes-(1) the state delegating to the municipality its clearly non-common-law duty to preserve law and order and (2) the state deterring riots through threat of liability ${ }^{58}$-would seem inconsistent with a subsisting common law duty in the municipality.

54 The first of the statutes is the Statute of Winchester, 13 Edw. I, c. 2 (1285). It was followed by the English Riot Act of 1714, 1 Geo. I, c. 5 (13 Stat. Large 142) (1714), and the Riot Damages Act, 49 \& 50 Vict., c. 38 (1886) (property damage only), which is still in force today. See the history of the acts in County of Allegheny v. Gibson's Son \& Co., $90 \mathrm{~Pa} .405$ (1879).

55 Sengstock, supra note 53 , at 423 , states that

the Statute of Winchester . . . sanctioned the practice in England that citizens of the "hundred" were liable for crimes committed in the neighborhood. Historical evidence convincingly establishes as fact that this practice was well rooted in the English way of life by the reign of Canute the Dane (1016-1035).

This would provide some support for the proposition that the statutes were declaratory of pre-existing common law rights against the municipality, but not against the state. With the common understanding in America at least that municipalities derive all power from the state, it is difficult to see how the state could create a common law duty (as opposed to waiving sovereign immunity) in its delegee which it did not itself have.

56 At first glance, the court in Schuster v. City of New York, 5 N.Y.2d 75, 154 N.E.2d 534, 180 N.Y.S.2d 265 (1958), might seem to have attached a legal duty to police protection. There, Mr. Schuster was shot to death three weeks after he reported to the police that he saw Willie Sutton, an escaped criminal. In a wrongful death action, based on negligence in police protection, plaintiff won. The court clearly stated, however, that its decision did not give every member of the public the right to enforce in the courts the duty of the police to preserve law and order. Rather, on the facts of this case, an enforceable duty arose out of the special relationship created when Schuster collaborated with the police and then asked for protection. Id. at 80-83, 154 N.E.2d at 537, 538, 180 N.Y.S.2d at 269-71. See Comment, Municipal Liability for Negligent Failure to Protect Informer: The "Schuster" Case, 59 CoLuM. L. REv. 487 (1959); cf. Huey v. Barloga, 36 U.S.L.W. 2389 (N.D. Ill., Dec. 27, 1967).

67 See statutes listed in note 166 infra.

58 See the fuller explication at text accompanying notes 206-12 infra. 
Moreover, there has neither been express nor implied recognition by any American court that such action will lie at common law. To the contrary, the courts have agreed with Mr. Justice Brandeis' assertion in Turner $v$. United States, that:

The fundamental obstacle to recovery is not the immunity of a sovereign to suit, but the lack of a substantive right to recover the damages resulting from failure of a government or its officers to keep the peace. ${ }^{59}$

Conversely, American courts have viewed statutes specifically allowing indemnification as based not upon any legal duty, but rather upon the permissive force of the police power and the municipality's political obligation to preserve social order within the community. The Supreme Court has stated:

Primarily, governments exist for the maintenance of social order. Hence it is that the obligation of the government to protect life, liberty, and property against the conduct of the indifferent, the careless, and the evil-minded, may be regarded as lying at the very foundation of the social compact. A recognition of this supreme obligation is found in [these] exertions of the legislative power . . . ${ }^{60}$

Even were one to assume that the duty to preserve law and order can be transmuted into an individual legal right, the competence ${ }^{61}$ of the courts to enunciate the proper standards of liability and to fashion adequate remedies is doubtful. ${ }^{62}$

59 248 U.S. 345, 357-58 (1918). Cf. Prather v. City of Lexington, $52 \mathrm{Ky}$. (13 B. Monroe) 559, 561-62 (1852) :

We know of no principle of law, that subjects a municipal corporation to a responsibility for the safety of the property within its territorial limits; nor has any case been cited in which such a principle has been recognized or established. . . There is nothing in the nature or design of a municipal corporation that imposes such a duty upon it. The chief purpose of such an institution is the adoption of such measures of police as will promote the comfort, convenience, and general welfare of the inhabitants within the city, and by local laws adapted to the condition of a dense population, to impart efficiency to the local government.

60 Sturges v. City of Chicago, 222 U.S. 313, 322 (1911).

61 The Supreme Court has suggested that whether a given subject is appropriate for judicial consideration depends upon "whether the duty asserted can be judicially identified and its breach judicially determined, and whether protection for the right asserted can be judicially molded." Baker v. Carr, 369 U.S. 186, 198 (1962).

$62 \mathrm{~A}$ rather quaint statement of one aspect of the problem was made by the Kentucky Supreme Court in 1852:

If such a liability exist, what is its nature and extent? Does it afford protection against the acts of the incendiary and the midnight depredator, or only against the violence of a lawless mob? If against the latter only, and not against the acts of others, whence arises this distinction? All the acts may be alike injurious, and if the corporation must secure the property of its members, in all events against all unlawful violence, there is no room for discrimination, but a similar liability would exist in each of the cases mentioned.

Prather v. City of Lexington, $52 \mathrm{Ky}$. (13 B. Monroe) 559, 561 (1852). 
If an action is to lie, the court will be required to properly employ negligence standards of doubtful relevance in the current riot situations. This can be illustrated through the old cases decided in states ${ }^{63}$ which condition statutory municipal liability on negligence by the local authorities. The courts translated this standard into the questions of whether the authorities had notice ${ }^{64}$ of the danger and whether, by exercising reasonable diligence, they could have prevented the damage from occurring. For example, where town officials knew that outlaws were close by, but were uncertain whether, or exactly when, they would attack, the court could find lack of adequate notice to the local authorities and consequently no liability. ${ }^{65}$ And where, despite adequate notification to the authorities of the danger to plaintiff from a mob already formed, the local authorities did not act at all, the court could hold negligence had been proved. ${ }^{66}$

Such standards of notice and diligence are not adequate to cope with the causes of modern urban riots, although they may fix the time and location of outbreak. Legislative choice of a negligence criterion may or may not be justifiable politically or otherwise; to create it judicially clearly is not. The question of reasonable diligence in suppression is inseparable from the more comprehensive social picture composed of such factors as police department manpower, jobs, public assistance, recreation programs and so on, long-term time-space parameters traditionally alien to judicial evaluation because of their inherently political character.

Moreover, without legislative instructions of the type found in the negligence-indemnification statutes, the judiciary would have to choose among local, state (if the city could not reasonably be held to control the current level of disorder), or possibly joint local-state responsibility, a determination more rationally based on the finances of compensation than on fault. ${ }^{67}$ Furthermore, quantification of indemnification (minimum amount of damage to qualify, maximum amount recoverable, percentage indemnification scheme) and conditions on indemnification ( size of city covered, nonparticipation by the claimant, type of damage

63 Conn. Gen. Stat. Ann. § 7-108 (1958); Kan. Stat. Ann. \$§ 12-203, -204 (Supp. 1967); KY. Rev. Stat. Ann. \$411.100 (1963); MD. Ann. Code art. 82, $\S \S 1-3$ (1957).

64 Cf. note 189 infra (notice requirement for absolute liability statutes).

65 See Tandy v. City of Hopkinsville, 160 Ky. 220, 169 S.W. 703 (1914).

66 Madisonville v. Bishop, $113 \mathrm{Ky}$. 106, 67 S.W. 269 (1902); Hagerstown v. Dechert, 32 Md. 369 (1869).

67 In Molitor v. Kaneland Community Unit Dist. No. 302, 18 Ill. 2d 11, 163 N.E.2d 89 (1959), the court was unable to prevent the school district, which it had held liable after abrogating sovereign immunity, from going insolvent, see P. MISHRIN \& C. Morris, ON LAW IN Courrs 313 n.15 (1965), while a subsequent Illinois legislature was within its normal realm of operations when it limited future recoveries in a single cause of action against a school district to $\$ 10,000$. ILL. Stat. ANN. ch. $122, \S 825$ (1962). 
covered, i.e., tangible or intangible, person or property) cannot be engrafted by the courts onto liability. ${ }^{68}$

To shift to a theory of indirect municipal liability predicated on the wilful or negligent action of an agent of the city, for example, a policeman who could be said to have "caused" the riot, will not alter the issue. Although the policeman's duty to provide protection derives from a different and more specific statutory source ${ }^{69}$ than the city's duty, it is the city's prior course of resource allocation which preconditioned the area to be riot-prone and to react to the incident with devastating effect. To hold the city liable through its policeman is indirectly to enter a political judgment on the city's resource decisions.

Once the riot has begun, the actions of policemen and firemen take on a different cast. Responsibility for the riot is no longer at issue; rather, the riot is merely an occasion for the exercise of the normal protective functions for which the legislature has created the departments.

The course of reported litigation makes it difficult to argue that the duty created by statutes to which the departments owe their existence comprehends liability for all ordinary tortious acts committed by department members; the chances of someone acting negligently somewhere and causing additional harm, especially in a riot context, are extraordinarily high, and it is unlikely that the legislature intended the city to be liable in these situations. However, it is at least strongly arguable that, though negligent acts do not violate the statutory mandate of fire and police protection, willful denial of protection does.

The argument can best be played out in the context of what happened in Cambridge, Maryland, on July 24-25, 1967. There, according to the New York Times, ${ }^{70}$ uncontrolled fires destroyed nearly two blocks of the city's Negro section. For two hours, firemen (of the volunteer fire department) refused to enter the Negro section

68 It is said that courts are ordinarily competent " . . . where there is blame on neither side, to ask, in view of the exigencies of social justice, who can best bear the loss and hence to shift the loss by creating liability where there has been no fault." "W. Prosser, TorTs 508 (3d ed. 1964). Certainly neither of two private parties to a tort action is in a better position than the court to adjust loss inter sese. With the example of the absolute liability provided for in most municipal indemnity statutes, see note 166 infra, it could be argued that absolute liability, which would at least solve the problem of viable negligence standards, should be imposed by the court. However, the government here is the party against whom absolute liability is sought to be assigned. The court is not needed to allocate the loss, and is in fact less competent than the legislature to determine whether governmental resources should be made available as the "insurance" proceeds of absolute liability.

Moreover, riot damage does not fall within the common law tradition creating absolute liability only when a defendant is both (1) operating an enterprise by his own choice and for his own advantage and (2) the activity is unusual and abnormal, or there is a high likelihood of danger, or the defendant is a better risk-bearer than the injured party. W. Prosser, supra, at 508-09.

69 The existence of police and fire departments is generally due to provisions in the city charters, see notes 145 (police) \& 100 (fire) infra, which are discussed in their relationship to a duty of police and fire protection at text accompanying notes 75-164 infra.

70 N.Y. Times, July 26,1967 , at 1 , col. 5 . 
while most of the equipment stood idle two blocks away; other trucks were used to water down a white business district only one block away.

While fire officials denied that ". . . vengeance had played a part in the firemen's refusal to respond . . ."71 and there is some evidence that the firemen did not go in for fear of their lives, ${ }^{72}$ there is other evidence that the failure was motivated by racial feelings. ${ }^{73}$ Although the Cambridge facts show an atypical chain of authority, ${ }^{74}$ the situation will be treated for purposes of analysis as though the firemen directly refused to follow orders of the responsible fire official.

\section{The Argument Parsed}

\section{a. Individual Liability ${ }^{75}$}

Firemen are not insulated from liability by their official capac-

71 Id. at 19 , col. 2 .

$72 I d$.

73 Id.

74 The Cambridge Chief of Police has testified that the fire department did not move into the ghetto because he declined to give clearance to the fire chief-out of regard for the fireman's safety because of shooting in the area. Hearings on H.R. 421 Before the Senate Comm. on the Judiciary, 90th Cong., 1st Sess., pt. 1, at 45-46 (1967). The Maryland Attorney General apparently countermanded the Police Chief's ruling, and ordered the fire department to act. N.Y. Times, supra note 70 , at 19 , col. 2 .

75 If the denial was for racial reasons, the firemen may be liable for damages under 42 U.S.C. $\$ 1983$ (1964) (action against any person for deprivation of "rights, privileges or immunities secured by the Constitution and laws" if acts performed "under color of any statute, ordinance, regulation, custom, or usage, of any State or Territory"); 42 U.S.C. $\$ 1985(3)$ (1964) (actions against persons conspiring to deprive "any person, or class of persons" of equal protection of the laws, if act in furtherance of the conspiracy injures another in person or property or deprives him of federally protected right); 42 U.S.C. \$1986 (1964) (action against person having knowledge of wrong mentioned in $\$ 1985$ and, having power to do so, refuses to prevent or aid in preventing); or for a civil conspiracy to violate $\$ 1983$. See cases cited in Scolnick v. Winston, 219 F. Supp. 836, 842 (S.D.N.Y. 1963).

Section 1983 requires that the action be "under color of" law, etc. The immediate problem in this respect would seem to be the familiar misfeasance-nonfeasance roadblock. Monroe v. Pape, 365 U.S. 167 (1961), holds that the action is "under color of" state law if it is misuse of authority possessed by virtue of a state law. It would seem that arbitrary refusal to exercise authority so possessed would fall under the same rubric, and at least one court has so held. Huey v. Barloga, 36 U.S.L.W. 2389 (N.D. Ill., Dec. 27, 1967). If not, however, proof of a local "custom or usage" of discrimination against Negroes should be sufficient. See Monroe v. Pape, 365 U.S. at 211, 216, 236-37 (Frankfurter, J., dissenting). And the section covers actions for denials of equal protection. Hague v. C.I.O., 307 U.S. 496, 526 (1939); Hoffman v. Halden, 268 F.2d 280, 293 (9th Cir. 1958).

Suits under $\$ 1985$ (3) require a conspiracy and overt acts thereunder; they may require that the action be taken "under color of" state law. See Collins v. Hardyman, 341 U.S. 651, 659, 661 (1951) ; 100 U. PA. L. REV. 121 (1951). The latter presumably would be no problem here, when state officers are the defendants. Furthermore, if a white businessman or slumlord is suing for damage to his ghetto property, he may have difficulty making out his case under $\$ 1983$, since it was the black ghetto residents who were discriminated against. Section 1985, however, deals with just this situation; the action is allowed to either the person injured (in person or property) or the person deprived of rights. An alternative action under $\$ 1986$ could be maintained if (1) some of the firemen could be found liable under $\$ 1985$ and (2) the remaining firemen could be shown to (a) have knowledge of the wrong, (b) have power to prevent it (i.e., to put out the fire themselves) and (c) have failed to do so.

A major burden, however, would be proof of a denial of equal protection. To a certain extent this would presumably depend on the fact-finder's evaluation of almost- 
ities. $^{76}$ Unless specifically excepted by statute, ${ }^{77}$ they owe the standard duty of care to the public. Ordinarily, however, there is no liability for non-feasance, ${ }^{78}$ that is, for not acting to extricate an individual from a dangerous situation or to protect property. In the Cambridge case the firemen were ordered to act. Unquestionably, they could be subject to fire department disciplinary action, ${ }^{79}$ and possibly even to criminal process $^{30}$ for dereliction in office for their failure to obey. The issue is whether the obligation to the department and the moral obligation to the citizen can also create a legal duty to the citizen for tort law purposes.

The most obvious source of a duty enforceable in tort is the order itself. The fire department was created for the public benefit and its orders are in furtherance of that purpose; they do not have merely internal ramifications. Breach of the fireman's obligation to the fire department is in turn a breach of the city's duty imposed by the legislature, ${ }^{81}$ since the city has relied on the fireman to carry out its responsibility in this respect. Therefore the statutory obligation was his and was breached. ${ }^{82}$ To this, it is often responded that there can be no private liability for breach of a public duty. ${ }^{83}$ The issue here is

doubtless conflicting testimony, and on the inferences he would be willing to draw from facts susceptible of proof. The Cambridge situation, where firemen watered down buildings in the white section of town while refusing to fight fires in the Negro ghetto, would seem to be a strong one; but in cities where even ghetto areas are partially integrated (e.g., many parts of Washington, D.C.) the plaintiff could have considerable trouble sustaining his burden of proof.

${ }_{76}$ E.g., Florio v. Jersey City, 101 N.J.L. 535, 129 A. 470 (Ct. Err. \& App. 1925); Ottoman v. Incorporated Village of Rockville Centre, 275 N.Y. 270, 273, 9 N.E.2d 862, 863 (1937) ("Public service should not be a shield to protect a public servant from the result of his personal misconduct"). Compare CAIIF. Gov't. CoDE $\$ 820$ (West 1966) (liability for act or omission as though private person) with id. $\$ 820.2$ (West 1966) (no liability for any act or omission resulting from exercise of discretion).

77 See, e.g., N.Y. GEN. Mun. Law \$205-b (McKinney 1965) (exemption for volunteer fireman for acts in performance of his duty unless wilfully negligent or malfeasant); $c f$. id. $\$ 50-b$ (cites to assume liability and save harmless paid firemen for negligence in driving vehicles). California and Illinois have by statute specifically barred individual liability for failure to provide fire protection. CALIF. Gov'T CODE $\$ 850$ (West 1966); ILL. STAT. ANN. ch. \$5, \$\$ 5-101, 102 (1966). See note 93 infra. 78 W. Prosser, Torts $\$ 54$, at 334 (3d ed. 1964).

79 E.g., N.J. Stat. ANN. $\$ 40: 47-6$ (1967) (disobedience of professional firemen as cause for removal).

80 See, e.g., WIS. STAT. ANN. $\$ 946.12$ (1958) (intentional failure to perform official duty a criminal offense).

81 See note 100 infra.

82 Cf. Regina v. Smith, 11 Cox Crim. Cas. 210 (Carlisle Assizes 1869), where defendant was a private tramway owner's employee, who was posted and strictly ordered to warn of trucks passing along the turnpike which crossed the tram's right of way. A death occurred by collision when defendant was absent from his post. The court found no criminal liability, but implied that had the job assumed by the employee been to fulfill a statutory duty of the employer, the employee could have been convicted of manslaughter.

83 It is most often stated that the only remedy, if any, for breach of a public duty is a public prosecution. See note 80 supra. Presumably this maxim includes internal department disciplinary procedures within the remedy of "prosecution." Leger v. Kelley, 19 Conn. Supp. 167, 110 A.2d 635 (New London County Super. Ct. 1954); Svenson v. Brix, 156 Ore. 236, 64 P.2d 830 (1937). 
whether the officer's "public duty" can never by that fact also be individualized. The problem is the same as for liability predicated on the city's "public duty" from which the fireman's derives, and will be discussed in the section on municipal liability. ${ }^{84}$

The duty may be derived independently of the statute from the relationship of firemen to citizens. Ordinarily liability is not imposed for failure to act when defendant stands in no different position toward plaintiff than any other human being. The situation is different, however, when defendant actively prevents aid from being rendered to plaintiff. ${ }^{85}$ There can be no doubt that if one took a bleeding man from the street and left him unattended in a house, he would be liable.

Prior to the mishap, the fireman assumed the job of firefighter and, at the very least, warranted to the city that he would follow orders, without necessarily guaranteeing competence and non-negligent future performance. Furthermore, if the city knew that he would not fulfill that undertaking by following orders, presumably another person would have been hired in his place. On this theory, plaintiff is hurt, not because the fireman frustrated the city's duty to fight fires, but because his implied assertion of loyalty in effect prevented the fact of protection that would have otherwise been available to plaintiff through the hiring of another fireman. The fact that the act which prevented aid was prior to and without specific knowledge of the fire which caused harm to plaintiff is logically irrelevant-the circumstance was certainly reasonably foreseeable. Liability for intentional disobedience ${ }^{86}$ may thus be predicated on familiar common law principles. ${ }^{87}$

84 See notes 90-112 infra and accompanying text.

85 See W. Prosser, supra note 78, at 342-43.

${ }^{86}$ Cf. note 137 infra.

87 In some circumstances, it might be unreasonable to order the fireman in, even though substantial risk of injury is a concomitant of his job, since a fireman cannot be held "as a matter of law to have voluntarily assumed all hidden, unknown, and extrahazardous dangers which in the existing conditions would not be reasonably anticipated or foreseen." Campbell v. Pure Oil Co., 15 N.J. Misc. 723, 727, 194 A. 873, 876 (Sup. Ct. 1937). Sniper fire is potentially a hazard which a fireman should not be held to have impliedly assumed when he undertakes to be a fireman, perhaps because his training to deal with the danger does not encompass criminal assault, or perhaps because he is more civilian than either a policeman or soldier.

The issue of unreasonableness of an order is usually litigated in the converse, namely whether the order should have been disobeyed. See, e.g., Neu v. McCarthy, 309 Mass. 17, 33 N.E.2d 570 (1941), holding that a soldier was not negligent when he ran a red light, because the order to do so was not clearly illegal, and it was therefore unreasonable to disobey. This type of precedent is not analytically helpful to the reasonableness of the disobedience of the fireman.

Fire departments and police departments are organized as quasi-military command units. Prima facie respect for the decision of the commanding officer is therefore warranted by the courts. The firemen have been reasonable not only in perceiving the danger to be extraordinary, but also in acting under that apprehension in the face of the order to act by the fire chief-who is the ordinary judge of the proper balance of danger and strategy. It should be noted, however, that "[a] study of 100 deaths that occurred in 3 cities failed to disclose a death that could be clearly attributed to a sniper's bullet . . . ." N.Y. Times, Feb. 25, 1968, §1, at 63, col. 3 . 
Even assuming individual liability, the remedy is clearly inadequate. It may be hard or impossible to identify the individual firemen responsible. More important, the chances of receiving a substantial amount in satisfaction of judgment are minimal - the average fireman's assets are likely to be insignificant, making him judgment-proof. ${ }^{88}$ The availability of an action against the city is thus of paramount importance. $^{89}$

\section{b. Municipal Liability ${ }^{90}$}

The acts of a municipal corporation are classified as private or public, depending on whether they serve a "proprietary" or a "legislative" (governmental) function. ${ }^{91}$ Where municipal immunity exists, liability attaches only to acts resulting from the exercise of the pro-

88The fireman, however, may be indemnified by the government. See, e.g., ConN. Gen. Stat. ANn. \$ 7-308 (1958) (for all sums the fireman becomes obligated to pay because of legal liability); MAss. GEN. LAws ch. 41, 100 (1966) (indemnification by city for expenses or damages incurred in defense or settlement of action). These statutes, however, may be construed not to cover cases such as the instant one because of limitations contained in them, as in the case of wilful action and activity not in the discharge of duty. E.g., Conn. GEN. Stat. ANn. \$7-308 (1958) (". . . if the fireman, at the time of the occurrence, accident, injury or damages complained of, was performing fire duties and if such occurrence, accident, injury or damage was not the result of any wilful or wanton act of such fireman in the discharge of such duties").

89 Although Connecticut, Kansas, Kentucky and Maryland condition statutory municipal indemnity on a showing that local officials had not exercised due care, see note 63 supra, the negligence involved goes to the failure to suppress and prevent the riot. If police or city officials were not at fault $a b$ initio, there is considerable doubt that subsequent fault of firemen would render the city amenable to suit.

90 Monroe v. Pape, 365 U.S. 167 (1961) held that a city was not a "person" under 42 U.S.C. \$ 1983 (1964). In general, then, federal civil rights statutes will be of little use for purposes of municipal liability. A question that Monroe did not answer, however, is whether, when a state has abolished municipal immunity, the city may be liable for the unconstitutional acts of its employees. This substantive issue would have to be settled by state law.

Another possibility is that presented by Duble v. Brown, No. 58-C-1712 (N.D. III.), (cited in National Lawyers Guild, Crvil. Rights \& Liberties Handbook 252), holding that where, under a state indemnity statute, see note 88 supra, the city must ultimately pay for any judgment against a policeman, the city may be made a party. Making the city a party in the first instance is likely to increase the possibility of a favorable jury verdict for plaintiff on damages.

91 E. McQuillin, The Law of Municipal Corporations $\$ 53.01 a$, at 105 (3d ed. rev. 1963) :

The city may be, and generally is, granted the same immunity against claims for damages for its acts done in its governmental capacity, that is, when it acts as the state's agent, as is enjoyed by the state in such matters. When acting in its proprietary capacity, as it is termed, or as a corporation, in like manner as a private corporation or an individual sui juris, the incorporated city or town, in the absence of some special exemption, is subject to all of the liabilities and usually entitled to all of the rights, immunities and benefits of the private law.

See the discussion in Note, Riot Insurance, 77 YALE L.J. 541, 547-51 (1968). 
prietary function; firefighting, a governmental action, is immune. ${ }^{92}$ In such jurisdictions, the Cambridge plaintiff is clearly barred..$^{92}$

Moreover, whether municipal immunity has been abandoned ${ }^{94}$ or not, a steady line of cases has explicitly denied recovery for "failure to provide fire protection." 95 This broad language, however, should not be taken at face value. These cases were concerned with the failure to establish a fire department, ${ }^{96}$ to keep it or its equipment at

92 In fact, the case law might support an assertion that firefighting (along with police service) traditionally has enjoyed greater immunity than other governmental functions. Compare Ball v. Village of Reynoldsburg, 176 N.E.2d 739 (Ohio Ct. App., Franklin County 1960) aff'd, 175 Ohio St. 128, 192 N.E.2d 51 (1963) (city liable for failure to maintain sewer line), with Aldrich v. Youngstown, 106 Ohio 342, 140 N.E. 164 (1922). But cf. Alva Steamship Co., Index No. 66 A.D. 622, at 23 (S.D.N.Y. 1967).

93 Also see the following statutory provisions: CaLIF. Gov'x. CoDe $\$ 850$ (West 1966) :

Neither a public entity nor a public employee is liable for failure to establish a fire department or otherwise to provide fire protection service.

ILt. Stat. ANN. ch. 85 (1966) :

\$ 5-101. Neither a local public entity nor a public employee is liable for failure to establish a fire department or otherwise to provide fire protection service.

\$ 5-102. Neither a local public entity that has undertaken to provide fire protection service nor any of its employees is liable for an injury resulting from the failure to suppress or contain a fire or from the failure to provide or maintain sufficient personnel, equipment or other fire protection facilities.

UTAH CODE ANN. \$63-30-10 (Supp. 1967), waiving immunity for acts or omissions of governmental employees, but excepting any claim that

". . arises out of or results from riots, unlawful assemblies, public demonstrations, mob violence and civil disturbances. . . ."

24 In spite of the statutory abrogation of immunity, New York lower courts continued to hold that the waiver does not extend to a "failure to exercise a government function." Murrain v. Wilson Line, Inc., 270 App. Div. 372, 375, 59 N.Y.S.2d 750, 753 (1946), aff'd per cutriam, 296 N.Y. 845, 72 N.E.2d 29 (1947) (policeman's failure to control crowd) ; Landby v. New York, N.H. \& H.R.R., 278 App. Div. 965, 105 N.Y.S.2d 839, motion for leave to appeal denied, 303 N.Y. 1014, 102 N.E.2d 840 (1951) (failure to remove dangerous wire); Mentillo v. City of Auburn, 150 N.Y.S.2d 94, 2 Misc. 2d 818 (Sup. Ct. 1956) (failure to exercise authority not actionable, while negligent exercise is). Murrain relied on Steitz v. City of Beacon, 295 N.Y. 51, 64 N.E.2d 704 (1945) (failure of fire protection), which, however, found no duty in the city rather than insulation through immunity. Later decisions of the $\mathrm{New}$ York Court of Appeals, however, seem to have conceded the statutory waiver. Canepa v. State, 306 N.Y. 272, 117 N.E.2d 550 (1954) (breach of duty to give highway warning made actionable by waiver of immunity); Schuster v. City of New York, 5 N.Y.2d 75,154 N.E.2d 534, 180 N.Y.S.2d 265 (1958) (liability for failure of police protection); Motyka v. City of Amsterdam, 15 N.Y.2d 134, 138, 204 N.E.2d 635, 636, 256 N.Y.S.2d 595,597 (1965) (liability for negligence of fire department determined by whether the city was "under a duty to plaintiff irrespective of sovereign immunity").

95 Where municipal immunity abandoned: Steitz v. City of Beacon, 295 N.Y. 51, 64 N.E.2d 704 (1945); Steinhardt v. Town of North Bay Village, 132 So. 2d 764 (Fla. Ct. App. 1961).

Where municipal immunity then in force: Edmondson v. Town of Morven, 41 Ga. App. 209, 152 S.E. 280 (1930); Small v. City of Frankfurt, 203 Ky. 188, 261 S.W. 1111 (1924); accord, Dalehite v. United States, 346 U.S. 15, 43 (1953) (dictum); cf. Note, Municipal Tort Liability, 50 CoR'NeLl L.Q. 699, 707 n.41 (1965). See also Note, Municipal Liability for Failure to Provide Police and Fire Protection, 15 Clev.-Mar. L. Rev. 296 (1966).

${ }^{86}$ Edmondson v. Town of Morven, 41 Ga. App. 209, 152 S.E. 280 (1930). 
sufficient strength ${ }^{97}$ or in proper working order. ${ }^{98}$ None of them involved the conscious (and arbitrary) decision not to fight a particular fire ${ }^{99}$ and would not preclude a contrary holding of liability in such a context.

The sine qua non of municipal liability is, of course, a breached duty. City charters commonly direct that municipalities shall provide fire protection. ${ }^{100}$ Yet courts have been reluctant to derive from the charters a concurrent duty that would subject the city to liability. ${ }^{101}$ Two reasons have been advanced for such decisions. First, it is said, the decision whether or not to provide fire protection is a policy decision, political in character, and should not be subject to judicial review..$^{102}$ However persuasively this rationale may apply to the choice of whether or not to form a fire department, and perhaps to questions of amount of equipment and general area of coverage, it does not extend to the deliberate withholding of available protection in

97 Thomas v. City of Los Angeles, 203 Cal. App. 2d 186, 21 Cal. Rptr. 398 (1962) (failure of sufficient length of hose) ; Small v. City of Frankfurt, $203 \mathrm{Ky} .188$, 261 S.W. 1111 (1924) (insufficient hose); Hughes v. State, 252 App. Div. 263, 299 N.Y.S. 387 (1937) (insufficient water, hose, pressure, men and equipment; otherwise known as "total failure"); Steitz v. City of Beacon, 295 N.Y. 51, 64 N.E.2d 704 (1945) (water valves in disrepair) ; Salvatore v. Carbondale Township, $69 \mathrm{~Pa}$. D.\&C. 79 (C.P. Lackawanna County 1948) (inadequate water supply and equipment).

98 Stang v. City of Mill Valley, 38 Cal. 2d 486, 240 P.2d 980 (1952) (clogged hydrant); Steinhardt v. Town of North Bay Village, 132 So. $2 d 764$ (Fla. Ct. App. 1961) (fire tank truck had insufficient water); Miller v. City of Minneapolis, 75 Minn. 131, 77 N.W. 788 (1898) (clogged hydrants) ; City of Columbus v. McIlwain, 205 Miss. 473, 39 So. 2d 921 (1949) (defective hydrant).

99 But cf. Motyka v. City of Amsterdam, 15 N.Y.2d 134, 256 N.Y.S.2d 595, 204 N.E.2d 635 (1965), denying recovery for failure to provide fire protection where the city took no action to remove an unsafe heater (of which it had knowledge and which was contrary to a safety code) from a multiple dwelling. The complaint did not, however, allege the failure to be the result of deliberate wrongdoing but appeared to attempt to base liability upon the failure to remove the heater without more.

100 Charters may be legislative enactments, e.g., New York CITY CHARTER $\$ 481$ (1963) ("There shall be a fire department, the head of which shall be the commissioner"); ChARTER OF THE CITY OF BEACON $\$ 24$ ("[The city] shall maintain fire, police, school and poor departments.") (cited in Steitz v. City of Beacon, 295 N.Y. $51,54,64$ N.E.2d 704, 705 (1945)), or locally adopted pursuant to an enabling constitutional or legislative provision, e.g., PhILAdelphIa Home Rule CHARTER, art. 5, ch. 4, §5-400 (1951) ("The Fire Department shall have the power and its duty shall be to ... extinguish fires at any place within the limits of the City ...."). Both types of charter have the same legal status, i.e., "legislative authority." E. MCQUiLlin, supra note $91, \S 9.08$.

Other statutory provisions, e.g., N.J. STAT. ANN. $\$ 40: 47-1$ (1967) are mere grants of power to maintain fire departments and do not in terms create any duty.

101 See, e.g., Steitz v. City of Beacon, 295 N.Y. 51, 64 N.E.2d 704 (1945).

102 California Law Reviston Commission, Recommendation Relating to SOVEREIGN IMMAUNITY $\S 28$, at 828 (1963):

Public entities should not be liable for failure to provide fire protection or for failure to provide enough personnel, equipment or other fire protection facilities. Whether fire protection should be extended at all, and the extent to which fire protection should be provided, are political decisions which are committed to the policy-making officials of government. To permit review of these decisions by judges and juries would remove the ultimate decisionmaking authority from those politically responsible for making the decisions. 
specific instances. The operation of a going public service, such as a fire department, is not a legislative function. ${ }^{103}$

The second rationale is that by creation of the charter duty to set up a fire department, the legislature has conferred a benefit to the public as a whole; as such, this duty cannot be the basis of liability to a particular citizen:

Quite obviousily, these provisions were not in terms designed to protect the personal interest of any individual and clearly were designed to secure the benefits of well ordered municipal government enjoyed by all as members of the community. ${ }^{104}$

The public-benefit-public-duty theory means that the statutory duty to provide fire protection is not equivalent to a duty to guarantee that each citizen receives that protection in every case of need. Rather, the rationale suggests: ${ }^{105}$

1. The benefit is to the citizenry as a class. One type of benefit (for example, that arising from efficient government) can be conferred to and be partaken of only by the polity as a whole. From a denial of this type of benefit, the individual incurs injury only to the extent of his membership in the community. Damages either do not exist or are impossible to ascertain; private compensation is inapposite. Other benefits are owed to the entire citizenry in the sense that they are owed to each and every citizen. The benefit here is properly characterized as public, not because it is not owed to an individual, but because it is owed to ail individuals. ${ }^{108}$

Fire protection falls within this last category. From its denial, individual injury is easily computed and private compensatory relief would seem appropriate. If the public benefit rationale can be invoked to continue to bar recovery, it can only be justified by asserting a

${ }_{103}$ See Doyle v. South Pittsburgh Water Co., 414 Pa. 199, 199 A.2d 875 (1964) holding, inter alia, that defendant water company could not rely (as an agent of the city) on cases where municipalities were not liable, since in those cases the duty to provide water was discretionary, whereas in this case the discretion had been exercised. "Discretion having been exercised and the physical fact of that exercise having become a fait accompli, reasonable care in the maintenance and repair of the planted hydrants became imperative." Id. at 206-07, 199 A.2d at 878.

104 Steitz v. City of Beacon, 275 N.Y. 51, 55, 64 N.E.2d 704, 706 (1945).

105 This analysis assumes that the public-benefit-public-duty rationale does not subsume a continued judicial reluctance to assess the city. To the extent that sovereign immunity survives in this unarticulated form, the arguments made here will be futile. Compare the following:

[T] he Legislature should not be deemed to have imposed such a risk when its language connotes nothing more than the creation of departments of municipal government, the grant of essential powers of government and Id. directions as to their exercise.

108 In Hale v. Johnston, 140 Tenn. 182, 203 S.W. 949 (1918) involving a suit against jail officials, the court classified two types of public duties: those owing solely to the state, and those owing to individuals as well. The court held that the fact that a duty is public does not bar liability in the latter class. 
residual benefit to the injured party in the protection afforded to other areas of the city. ${ }^{107}$ That is, so long as the city is still providing "fire protection" to the polity as a whole, the plaintiff continues to receive the required benefit. This part of the benefit, then, is not that his house not burn down, but rather a more general one-that the whole city not burn down from lack of fire protection.

2. In order to best provide for the general welfare, it is possible that the interests of a few citizens may have to be sacrificed. Implementation of this principle of the greatest good for the greatest number requires some measure of discretion (albeit non-legislative) as to the allocation of resources. It is then further argued that to subject this discretion to judicial review would interfere detrimentally with the department's performance. ${ }^{108}$

In the Cambridge situation, neither of these qualifications on the charter privilege applies. Relief was denied not to one or a few individuals, but to a significant segment of the population. ${ }^{109}$ Consequently, it cannot be said that the citizenry as a group had the benefit of fire protection. ${ }^{110}$ Furthermore, the discretion protected under the public benefit rationale had been exercised when the fire chief ordered his men to move in. An existing fire department, from all initially legitimate courses of action open to it, had committed itself to a particular one, creating a situation where "discretion" should receive no further deference.

In sum, denying protection to plaintiffs in such situations clashes with even the modest statutory mandate to provide general fire protection. In such circumstances, employing the statute as a basis for

107 Although positing the residual benefit is adequate to explain the case law, it is perhaps quite plausible to suggest that the case results have no justification at all, and are attributable to the type of concern noted in note 105 supra.

108 Cf. McGee v. Adams Paper \& Twine Co., 26 App. Div. 2d 186, 271 N.Y.S.2d 698 (1966).

109 If, of course, the denial of relief amounts to a denial of equal protection, the policy arguments against the existence of a legitimate public benefit will be even stronger.

110 Procedurally, this point will be manifested in one of two ways: as a necessary allegation in the complaint; or as a class action. If the latter is available in the jurisdiction it would appear preferable, since aside from demonstrating plaintiffs' status as a member of a large group, it would also guard the city against a multiplicity of suits, and would guard individual plaintiffs against potential exhaustion of available assets.

The plaintiff, then, must allege first, that the action was not within the range of permissible discretion (discretion was exercised and not implemented, or discretion was abused); and second, that the denial of protection was to a significant portion of the population. Note that it is not necessary to allege that others were actually burned out, merely that they were not afforded the protection against fire. This becomes crucial when plaintiff is one of a very few who were actually damaged. 
municipal liability is not inconsistent with legislative intent; ${ }^{111}$ indeed, analogous precedent would command liability. ${ }^{112}$

Reinforcing the bare statutory mandate argued for is the tradition of common law liability for failure to act in certain situations. In cases where the defendant has by his intervention made plaintiff's plight worse, he is not allowed to withdraw with impunity. ${ }^{113}$ Although it is difficult to argue specific reliance in the form of alternatives foregone, ${ }^{114}$ the reliance is no less real than that placed on those engaged in "public callings," upon whom the law imposes liability for nonfeasance. ${ }^{115}$ The obligation of common carriers, public utilities and innkeepers to serve the public can only be explained in terms of societal reliance which raises expectations the law will not permit to be frustrated. The essential and basically monopolistic social service performed by a fire department is not different in kind.

Technically, it is possible to argue that this reliance has existed from the beginning; that its presence did not at the outset create any duty to the individual because of a superior and competing need to allow operative discretion in the deployment of limited resources. Therefore, common law principles can neither reinforce nor help individualize the city charter mandate by adding elements of duty because there has been no additional reliance or new harm to the plaintiff since the fire chief gave his orders. It is apparent, however, that each citizen's reliance creates a duty to serve him, subject only to the requirements of the general public, which have been met when the course of action has been finally determined. The duty existed all along, conditional on the exercise of the fire chief's discretion; at this point, the condition has been removed. ${ }^{116}$

111 In jurisdictions where the issue of duty created by the city charter is approached as partially one of statutory construction, see note 105 supra, the statute would now seem to require liability.

112 See, e.g., cases at note 146 infra, imposing liability on cities (sometimes even as an exception to municipal immunity) for the failure to protect prisoners in violation of statute. Shorn of the insulation of the public benefit rationale, cases of failure to provide fire protection are in the same posture.

113 W. Prosser, TorTs, § 54, at 342 (3d ed. 1964) :

In most of the cases finding liability the defendant has made the situation worse, either by increasing the danger, or by misleading the plaintiff into the belief that it has been removed, or depriving him of the possibility of help from other sources, as where he is induced voluntarily to forego it.

114 One could point to the possibility that the ghetto resident might have procured more fire insurance, formed a volunteer fire company or moved away altogether, had he known he would be denied protection. Perhaps the individual's lack of resources to make these alternatives real does not moot the contention when an entire group is involved.

115 See, e.g., Nevin v. Pullman Palace Car Co., 106 I1l. 222 (1883) (failure to permit use of sleeping car berth); Capital Elec. Power Ass'n v. Hinson, 230 Miss. 311, 92 So. 2d 867 (1957) (liability for intentional refusal to render service).

116 This is consistent with Mentillo v. City of Auburn, 2 Misc. $2 d 818,150$ N.Y.S. $2 d 94$ (Sup. Ct. 1956), where plaintiff was shot by an insane man. Recovery on the basis of a general duty to afford police protection was denied. However, since a policeman was detailed to take the man into custody, but did not, liability was imposed on the city for the policeman's negligence. 
If the individual fireman is liable for his refusal to act, the city also may be reached under the doctrine of respondeat superior. Assuming that some court might be unwilling to find the fireman individually liable, however, orthodox doctrine will not work and the city's duty must create liability standing alone. Whether the city should be held liable when it has done all it reasonably can be expected to do in regard to selection, instruction and supervision of its subsequently disobedient firemen ${ }^{177}$ is an issue which is obscured in litigation when respondeat superior is employed. The issue must be met, however, if a court decides that the servant's duty to the city does not extend to the public for purposes of employee liability, and yet is to form the factual basis for municipal liability.

When respondeat superior is rationalized, ${ }^{118}$ it is first pointed out that it is used as a means of transferring the risk to the assumed better-risk-bearing employer, not from the employee, but from the plaintiff. This is true even where the government is the employer. It is further argued that:

If masters were not liable for their servants' failures to act with reasonable considerateness for the safety of others they might have less incentive to discipline servant's [sic] guilty of such lapses-particularly when a servant has been overdiligent in protecting his master's interests at the expense of others. Liability probably inspires discipline for misconduct that might not otherwise be forthcoming. Servants who cannot be reached by law directly are deterred from committing torts by threats of discipline evoked by the legal responsibility of their masters. ${ }^{119}$

That a court would have declined to impose liability on the fireman does not mean that his refusal to enter the fire area was not wrongful. Rather it suggests only that his wrongful conduct will be

117 An alternative suggestion is to make the action depend on fault, yet view a showing that the city had hired firemen who in fact refused to obey orders to fight fires as establishing a prima facie case for plaintiff. When the city goes forward with evidence of hiring, training and disciplinary procedures, however, plaintiff is still faced with the insuperable task of showing where they failed.

The city should have the defense, here as well as where respondeat superior obtains, that it was unreasonable to order the firemen in under the circumstances. See note 87 supra. If the order were unreasonable, the fireman's decision was not in any way wrongful; the protection afforded plaintiff was all that existing resources could reasonably be expected to provide under the circumstances.

Litigation of the reasonability of the order is not inconsistent with a policy against judicial review of official discretion, treated in text accompanying notes 123-131 infra. If the order is found to be unreasonable, the city is not liable and the only ill effect is subjecting the fire chief's decision to public scrutiny in the course of the litigation against the city. The city, however, is in a position to make an independent judgment of the reasonability of the order and, if it thinks the order warranted (and the firemen therefore wrong), it can waive the defense, pay the claims and thereby protect its official from the rigors of judicial review.

118 See, e.g., C. MORRIs, TORTS 253-55 (1953).

119 Id. at 255. 
more appropriately remedied through internal departmental disciplinary procedures than in a damage action. Where such discipline is unlikely to be forthcoming, as was the case after the Newark riots where there was evidence of the use of excessive force by the police, ${ }^{120}$ and as is likely to be the situation in the Cambridge-type racial climate, the encouraging of discipline through city liability is particularly apt. ${ }^{121}$ This result emphatically does not make the city a general insurer of property against fire. ${ }^{122}$ Previous analysis has posited the following before imposing liability: the extent of the duty of fire protection does not exceed the amount of resources the city can, or will (in its legislative discretion) provide; since those resources are limited, there is no guarantee that every citizen will receive his benefit; the city must therefore have the right to distribute the benefit in accord with the requirements of the general welfare. Liability without proof of fault operates only where those requirements are settled in favor of a given course of action and the purpose of the entire discretionary process has been frustrated by the refusal to take it to its logical end in effective fire fighting.

Somewhat different from the refusal of a fireman to obey his orders is the case where such orders are never given. Public policy has been argued to require that the responsible fire official be given some freedom of choice in his deployment of forces, and that this discretion be unreviewable. The result is an apparent paradox: the city can be found liable if it orders its men to fight a fire and they fail to do so, but not if the city never gives the needed order. The answer is that in both cases, the court is relying on similar exercises of discretion by the fire chief, assuming that his good faith and good judgment have determined what the public benefit requires. Thus, when the decision is made not to act, it is taken that the public benefit does not require action, and vice versa.

Yet it is not inconsistent with a desire not to unduly constrain discretion ${ }^{123}$ to subject it to some review. Whether or not there

120 The Select Commission on Civil Disorder named by Gov. Richard J. Hughes of New Jersey to investigate the Newark and other 1964 New Jersey riots, cited evidence that state police and National Guardsmen had deliberately fired on "innocent bystanders" and intentionally damaged stores believed to be owned by Negroes.

The Commission said it was very "disturbed" that seven months after the riots there had been no report of any disciplinary action against police and Guardsmen who were charged with using excessive force. Phila. Inquirer, Feb. 11, 1968, $\$ 2$, at 18, col. 5 .

121 There is some warrant in precedent for this differential approach to the city and its employees in Lipman v. Brisbane Elem. School Dist., 55 Cal. 2d 224, 230, 359 P.2d 465, 467, 11 Cal. Rptr. 97,99 (1961). But see Ill. Stat. Awr. ch. 85, §2-109 (1966): "A local public entity is not liable for an injury resulting from an act or omission of its employee where the employee is not liable."

122 Compare text accompanying notes 61-68 supra.

123 Discretion here refers to that used in the administration of a going department, see text accompanying note 108 supra, as opposed to legislative discretion in deciding whether to establish a fire department. See text accompanying note 102 sitpra. 
should be review must depend on the consequences both of suits against the city ${ }^{124}$ and of suits against the individual fire chief. ${ }^{125}$

The objections to such review are basically twofold. First, the competence of the judiciary to insinuate itself into the management of an operation requiring expertise and technical skill is held to be particularly minimal-judges and jurors are all laymen in this regard. ${ }^{\mathbf{1 2 6}}$

124 There is statutory authority that there can be no municipal liabliity for the exercise of a discretionary function, even if the discretion is abused. See, e.g., CALIF. Gov'r CODE § 820.2 (West 1966); Irx. Star. ANN. ch. 85. \$\$2-109, -201 (1966); UTAH CODE ANn. \$ 63-30-10(1) (Supp. 1967).

So also held the recent case of In re Alva Steamship Co., Ltd., Index No. $66 \mathrm{AD}$ 622 (S.D.N.Y. Jan. 4, 1967), following Amato v. City of New York, 268 F. Supp. 705 (S.D.N.Y. 1967). Amato characterized New York law as establishing that the city "continues to be immune in respect of acts and determinations which are discretionary." Id. at 707. The court there relied in part on Weiss v. Foote, 7 N.Y.2d 579, 167 N.E.2d 63, 200 N.Y.S.2d 409 (1960) (concerning the timing sequence of a traffic signal). Weiss, however, while expressing concern over judicial review of discretionary functions, did not hold that the city was immune in that respect and, in fact, reserved the case where "due care was not exercised in the preparation of the design or that no reasonable official could have adopted it . . . " Id. at 586, 167 N.E.2d at 66,200 N.Y.S.2d at 413.

We are of the opinion that the traditional reliance on a jury verdict to assess fault and general tort liability is misplaced where a duly authorized public planning body has entertained and passed on the very same questions of risk as would ordinarily go to the jury. Although a jury verdict is to be highly regarded, it is neither sacrosanct nor preferable to the judgment of an expert public planning body. For this reason, liability for injury arising out of the operation of a duly executed highway safety plan may only be predicated on proof that the plan either was evolved renthout adequate study or lacked reasonable basis.

Id. at 588-89, 167 N.E.2d at 66, 200 N.Y.S.2d at 413 (emphasis added). Cf. Jaffe, Suits Against Governments and Officers: Damage Actions, 77 HARv. L. Rev. 209, 237 (1963). See also Raven v. Coates, 125 So. 2d 770 (Fla. App. 1961); 28 U.S.C. $\$ 2680$ (a) (1964), excepting from the Federal Tort Claims Act claims

- . based upon the exercise or performance or the failure to exercise or perform a discretionary function or duty on the part of a federal agency or an employee of the Government, whether or not the discretion involved be abused.

125 When public officers must exercise judgment and discretion they are thought to enjoy "quasi-judicial" powers and a concomitant immunity from liability. Cooper v. O'Conner, 107 F.2d 207, cert. denied, 308 U.S. 615 (1939); People v. Standard Acc. Ins. Co., 42 Cal. App. 2d 409, 108 P.2d 923 (1941); Johnson v. Steele County, 240 Minn. 154, 60 N.W.2d 32 (1953) ; Ill. Stat. ANN. ch. 85 \&2-201 (1966); WIS. STAT. ANN. \$895.43(3) (1966). There is a division of authority over whether this immunity is complete, or excepts acts of malice, willfulness or bad faith. Compare Norton v. McShane, 332 F.2d 855 (5th Cir. 1964) (dictum), cert. denied, 380 U.S. 981 (1965); Wilson v. Hirst, 67 Ariz. 197, 193 P.2d 461 (1948); Ill. Stat. Ann. ch. 85 \$2-201' (1966) with Commercial Trust Co. v. Burch, 267 F. 907 (S.D. Ga. 1920); Price v. Owen, $67 \mathrm{Ga}$. App. 58, 19 S.E.2d 529 (1942).

126 See McGee v. Adams Paper \& Twine Co., 26 App. Div. 2d 186, 271 N.Y.S.2d 698 (1966) (expert testimony as to common fire fighting practice held inadmissable because apt to mislead inexperienced lay jurors).

In distinction to this, the discretion of corporate directors is unarguably wide, yet subject to review when abused. See Dodge v. Ford Motor Co., 204 Mich. 459, 170 N.W. 668 (1919).

A flexible approach to the problem is suggested by Lipman v. Brisbane Elem. School Dist., 55 Cal. 2d 224, 359 P.2d 465, 11 Cal. Rptr. 97 (1961). While holding to the rule of discretionary immunity when individual liability is at stake, the court admits that the detrimental effect on the exercise of official duties is somewhat less when it is the liability of the city alone that is in issue. Thus, it lists a number of 
Second, since the officer is duty-bound to act, it is considered unfair to subject him to liability for a mistake made in good faith. Even where the fire official is not called on to pay damages (for example, where there is indemnification from the city), there is still the embarrassment of having been adjudged to have done wrong. Adding a requirement of malice does not eliminate the threat to the innocent fire chief. So long as he is amenable to suit, he will fear court action where he may be called upon to prove the good faith of a difficult decision. Where institutional disciplinary remedies ${ }^{127}$ for control of official conduct are available, it is thought that the combination of the vagaries of private suit and uncertainty of the judicial process may unnecessarily dampen official ardor that ought properly be encouraged $^{128}$ This consideration applies to suits both against individual and city. It goes not to the merits of recovery when malice is in fact present, but to the chilling effect the possibility of liability has on permissible and warranted action. ${ }^{129}$ But where public control mechanisms are available only in theory, but not in fact, ${ }^{130}$ the picture changes. Then the objection to private-action liability loses its potency because it becomes clear that city liability might be required as the only possible, albeit heavy-handed, means for effectuating any control of public officers. ${ }^{131}$

\section{c. Extent of Liability}

Perhaps the most perplexing problem of all is the extent of liability for a massive conflagration that levels a large area. ${ }^{132}$ Suppose that

factors that should be weighed in a given case to determine whether the city is immune:

. . the importance to the public of the function involved, the extent to which governmental liability might impair free exercise of the function, and the availability to individuals affected of remedies other than tort suits for damages.

55 Cal. 2 d at 230,359 P.2d at 467, 11 Cal. Rptr. at 99.

127 These would range from reprimand through dismissal, as well as criminal prosecution.

128 See Barr v. Matteo, 360 U.S. 564, 571 (1959); Gregoire v. Biddle, 177 F.2d 579, 581 (2d Cir. 1949) (Learned Hand, J.), cert. denied, 339 U.S. 949 (1950); Jaffe, supra note 124 , at 223 . But see 2 F. HARPER \& F. JaMrs, THe Law of TorTS $\$ 29.10$, at 1645 (1956): "But it is stretching the argument pretty far to say that the mere inquiry into malice would have worse consequences than the possibility of actual malice..." (emphasis added).

129 It could be argued that this consideration does not apply to the instant case, since when the choice is between action and non-action, the latter ought not to be encouraged. This view overlooks the fact that a decision not to respond in one instance can be made because the resources are better used elsewhere, or because it would be better to hold them in reserve, in contemplation of upcoming serious danger.

130 See note 120 supra and accompanying text.

131 See text accompanying note 119 sitpra.

The analysis above has been directed to jurisdictions that have abolished municipal immunity. Some states have merely modified immunity, granting recovery for the exercise of governmental functions only for affirmative wrongdoing. Allas v. Borough of Rumson, 115 N.J.L. 593, 181 A. 175 (Ct. Err. \& App. 1935); Levene v. City of Salem, 191 Ore. 182, 229 P.2d 255 (1951). The active wrongdoing doctrine is often 
during the two-hour Cambridge delay, the fire ran out of control: would the city be liable to a plaintiff in a remote section of the city, whose property was eventually destroyed, but to whose call the fire department responded in the ordinary and unimpeachable manner? In the landmark case, $H$. R. Moch Co. v. Rensselaer Water Co., ${ }^{133}$ Chief Judge Cardozo declined to assess damages against defendant private company for negligent failure to provide adequate water pressure, alluding to the "crushing burden that the obligation would impose:" 134

If the plaintiff is to prevail, one who negligently omits to supply sufficient pressure to extinguish a fire started by another, assumes an obligation to pay the ensuing damage, though the whole city is laid low. ${ }^{135}$

The questions that Moch raises here are: (1) can liability be limited in scope; and (2) if not, does the Moch rationale compel a holding of nonliability.

invoked concurrently with other theories of liability. While there is some question as to just how closely these theories are linked, a few jurisdictions expressly combine them. Bacon v. Town of Rocky Hill, 126 Conn. 402, 11 A.2d 399 (1940) (creation of nuisance by positive act); City of Nashville v. Mason, 137 Tenn. 169, 192 S.W. 915 (1916) (affirmative act of wrongdoing in creating a nuisance),

One court has recognized that it is a ". . . fine line which may separate active wrongdoing from a mere failure to act," Cloyes v. Township of Delaware, 23 N.J. 324, 330,129 A.2d 1, 4 (1957), and that it may depend on how the wrong is characterized. The same court held actionable as an affirmative wrong the failure of a police department to train a reserve patrolman which resulted in the negligent shooting of plaintiff. McAndrew v. Mularchuk, 33 N.J. 172, 162 A.2d 820 (1960). In another jurisdiction, the failure to provide adequate supervision over school children during a school recess was a positive act. Sestero v. Town of Glastonbury, 19 Conn. Supp. 156, 110 A.2d 629 (Super. Ct., Hartford County 1954) (act created dangerous condition which was a nuisance).

New Jersey appears to be alone among these states in requiring that active wrongdoing be "chargeable to the municipality in order to render it liable.", Florio v. Jersey City, 101 N.J.L. 535, 129 A. 470, 471 (Ct. Err. \& App. 1925), by being perpetrated by "an agent or agents of the borough high enough in the echelon of general authority in the administration of the police department to justify a finding by the jury that the borough itself committed or participated in the commission of the act." McAndrew v. Mularchuk, 33 N.J. at 182, 162 A.2d at 826 . Thus, the city could not be liable for the wrong of the firemen, unless plaintiff can show negligence in hiring, training or discipline on the part of the department. Liability might be found for the positive mismanagement by the fire chief in not giving proper orders to combat the blaze, since, as "the person entrusted with administrative control of the department," id. at $185,162 \mathrm{~A} .2 \mathrm{~d}$ at 827 , he can bind the city. The city's liability via the fire chief is clouded however by Hoy v. Capelli, 48 N.J. 81, 222 A.2d 649 (1966), where the court, although not overruling $M c A n d r e w$, espoused the doctrine of discretionary immunity for a city's planning in removing a traffic light.

132 Plaintiff's burden of causation in fact in regard to whether his house would have been damaged to such a degree absent the failure of protection, while difficult to meet, is not impossible. See, e.g., Gilbert v. New Mexico Constr. Co., 39 N.M. 216, 44 P.2d 439 (1935), where the court held that the question whether a defendant's negligence in breaking a water main caused the fire loss was properly given to the jury.

133247 N.Y. 160,159 N.E. 896 (1928).

134 Id. at 165,159 N.E. at $897-98$.

135 Id. at 166,159 N.E. at 898. 
One possible way to limit liability is to confine it to damage within the scope of the intended denial. This can be justified on the ground that the city will not be liable for a merely negligent failure of protection. The only complaint of the citizen in a remote area of the city, therefore, is that the firemen (possibly from an altogether different fire precinct) were negligent in not containing the fire, a risk to which he ordinarily must submit whenever a fire breaks out. ${ }^{136}$

If this mode of limiting liability is not appealing, should the possibility of tremendous liability bar suit under Moch? ${ }^{137}$ The "crushing burden" rationale pertained only to plaintiff's first theory that the contract for water with the city was made for his benefit. Judge Cardozo contrasted the restrictive New York rule as to liability for the spread of fire negligently set, ${ }^{138}$ and concluded that a promisor could not have intended to assume "a risk so overwhelming for any trivial reward." 139 However, there is no contractual intent to construe here. The only issue as to tort liability was whether defendant's posture under the contract brought it into such a relation with everyone potentially benefited so as to create a duty. In this case, that issue presumably has been resolved. ${ }^{140}$

Abstracting the "crushing burden" rationale from its contract setting in Moch, ${ }^{141}$ we still might ask whether there is anything about a city such that liability should be imposed on it, while withheld from a private company, or vice versa. By hypothesis, the jurisdiction is one in which the declared state policy is to allow recovery from municipalities. ${ }^{142}$ Furthermore, while enormous liability will easily

136 But holdings that it could not reasonably be foreseen that a negligently set fire would rage out of control rely on the premise that one can reasonably expect that the fire will be put out at some point. That premise disappears when the wrong focused on is the intentional withholding of the forces that will put the fire out. Arguably, the opposite result from that urged in the text is required: since the wrong is so much more serious, liability for all damage should ensue.

137 Chief Judge Cardozo himself stated: "We do not need to determine now what remedy, if any, there might be if the defendant had withheld the water or reduced the pressure with a malicious intent to do injury to the plaintiff or another." 247 N.Y. at 169,159 N.E. at 899 . Moreover, the Moch holding, even on its facts, is not followed in all jurisdictions. See, e.g., Doyle v. South Pittsburgh Water Co., $414 \mathrm{~Pa}$. 199, 199 A.2d 875 (1964).

138247 N.Y. at 166,159 N.E. at 898.

$139 \mathrm{Id}$.

I40 See text accompanying notes $100-16$ supra.

141 E.g., Steinhardt v. Town of North Bay Village, 132 So. 2d 764, 766 (Fla. Ct. App. 1961).

142 See Antieau, Statutory Expansion of Municipal Tort Liability, 4 ST. Lours U.L.J. 351, 371-72 (1957) :

[I]f the determination of municipal responsibility in tort is for the legislatures (as the courts continually insist), then determination of whether civic responsibility in a particular group of cases will constitute "a crushing burden" is not for the conjecture of the courts. Judges who believe that they have no authority to hold municipalities responsible for their delicts in the absence of statute, should, by the same token, have no prerogative to amend a general waiver of immunity by the legislature. 
bankrupt a private company, a city has ways of raising funds not open to the former. ${ }^{143}$ Thus it will be the highly extraordinary case where a city faces bankruptcy as a result of liability. ${ }^{144}$

\section{d. Failure to Provide Police Protection ${ }^{145}$}

Numerous cases also hold that there is "no recovery for failure to provide police protection." ${ }^{146}$ But there is doubt whether the

143 These include the taxing (as well as bond issuing) power (which may both have restrictions) and state legislative appropriation. Mandamus may be available to compel use of the tax power to satisfy a judgment. See Note, Municipal Liability for Riot Damage, 81 HARv. L. REv. 653, 656 n.121 (1968).

144 But cf. note 67 supra. Insurance may be a means of reducing potential liability. Existing policies insure the city against liability incurred through its employees. Beyond that, if the tortious conflagration is limited, as in Cambridge, to a two-block area, while the riot, looting and other fire damage covers an entire ghetto, the ultimate municipal liability will be considerably less than that under a theory holding the municipality liable for all riot damage.

145The basic legal framework is the same as for fire protection. Comparable charter provisions are NEW YORR CITY ChARTER \& 435a (1963):

The police department and force shall have the power and it shall be their duty to preserve the public peace, prevent crime, detect and arrest offenders, suppress riots, mobs and insurrections, disperse unlawful or dangerous assemblages which obstruct the free passage of public streets, sidewalks, parks and places; protect the rights of persons and property, . . . enforce and prevent the violation of all laws and ordinances in force in the city; and for these purposes to arrest all persons guilty of violating any law or ordinance for the suppression or punishment of crimes or offenses.

Philadelphia Hone Rule Charter, art. 5, ch. 2, § 5-200 (1951) :

The Police Department shall have the power and its duty shall be to . . . preserve the public peace, prevent and detect crime, police the streets and highways and enforce traffic statutes, ordinances and regulations relating thereto.

See provisions collected in Goldstein, Police Discretion Not to Invoke the Criminal Process: Low-Visibility Decisions in the Administration of Justice, 69 YALE I.J. 543,557 n.26 (1960).

With respect to individual liability, policemen are similarly protected and indemnified. Here there is another possible source of funds for the vindicated plaintiff. Police officers often take out official bonds for the faithful performance of the office. This source will not add any additional ground of liability since it usually is held, at least in an individual suit on a bond (as opposed to one brought by the government), that the bond does not create liabilities that do not otherwise exist, and therefore, statutory obligations that would not sustain a suit at common law will not do so in a suit against the surety. See, e.g., State ex rel. Boone Nat'l Bank v. Manns, 126 W. Va. 643, 29 S.E.2d 621 (1944).

146 Cases not relying on municipal immunity: Campbell's Adm'x v. City Council of Montgomery, 53 Ala. 527 (1875) ; Adamczyck v. Zambelli, 25 I11. App. 2d 121, 166 N.E.2d 93 (1960); City of Lafayette v. Timberlake, 88 Ind. 330 (1882); Murrain v. Wilson I.ine, Inc., 270 App. Div. 372, 59 N.Y.S.2d 750 (1946), aff'd, 296 N.Y. 845, 72 N.E.2d 29 (1947); King v. City of New York, 3 Misc. $2 d$ 241, 152 N.Y.S.2d 110 (Sup. Ct. 1956); Little v. City of Madison, 49 Wis. 605, 6 N.W. 249 (1880).

Cases relying on municipal immunity: Gianfortone v. New Orleans, 61 F. 64, (E.D. La. 1894) ; Wood v. Cox, 10 Cal. App. 2d 652, 52 P.2d 565 (1935) (by implication); Woodford v. City of St. Petersburg, 84 So. 2d 25 (Fla. 1955); Parks v. Town of Princeton, 217 N.C. 361, \& S.E.2d 217 (1940) ; Western College v. City of Cleveland, 12 Ohio St. 375 (1861); Brogan v. City of Philadelphia, 346 Pa. 208, 29 A.2d 671 (1943) ; Norristown v. Fitzpatrick, $94 \mathrm{~Pa} .121$ (1880); O'Rourke v. City of Sioux Falls, 4 S.D. 47, 54 N.W. 1044 (1893); Stinnett v. City of Sherman, 43 S.W. 847 (Tex. Civ. App. 1897).

See also the complete bar set up in IlL. Stat. ANN. ch. 85, \$4-102 (1966), paralleling the similar provisions for fire service, set out in note 93 supra. But see 
analysis used to explain the fire cases is equally applicable here. This is because it is sometimes thought that discretion in law enforcement has no place in the police department ${ }^{147}$ - thus leaving the "public duty" formula reduced in content to the sole element of public benefit. ${ }^{148}$

In those few cases where courts have been directly confronted with the issue of police discretion, they have uncritically accepted the idea that the police role is purely ministerial. ${ }^{149}$ Yet there is no doubt that the police do in fact exercise discretion. ${ }^{150}$ It is important to note that this discretion is not univocal and may be separated into at least two different categories: allocating limited resources, ${ }^{151}$ and making quasi-

for suits under 42 U.S.C. $\$ 1983$ (1964), Monroe v. Pape, 365 U.S. 167, 242-43 (1961) (Frankfurter, J., dissenting); Huey v. Barloga, 36 U.S.L.W. 2389 (N.D. I11., Dec. 27, 1967); note 75 supra.

Yet, as in the case of fire protection, these holdings do not extend to the full sweep of the language. Courts have not been absolutely unwilling to impose liability for police failure, as in the case of failure to provide protection to an informer. Gardner v. Village of Chicago Ridge, 71 Ill. App. 2d 373, 219 N.E.2d 147 (1966); Schuster v. City of New York, 5 N.Y.2d 75, 154 N.E.2d 534, 180 N.Y.S.2d 265 (1958). This fits squarely within the public benefit rationale-the theory being that ordinary discretion and allocation of resources must defer to the greater public benefit in encouraging willing collaboration with the police by protecting those who come forward to help the police.

If it were otherwise, it might well become difficult to convince the citizen to aid and co-operate with the law enforcement officers . . . . To uphold such a liability does not mean that municipalities are called upon to answer in damages for every loss caused by outlaws or by fire. Such a duty to Schuster bespeaks no obligation enforcible in the courts to exercise the police powers of government for the protection of every member of the general public.

Id. at 80-81, 154 N.E.2d at 537,180 N.Y.S.2d at $269-70$.

In another type of case, liability is imposed on the city for failure to safeguard prisoners in jail. Edwards v. Town of Pocahontas, 47 F. 268 (W.D. Va. 1891) (city liable for condition of jail as proprietary function); Hargrove v. Town of Cocoa Beach, 96 So. $2 \mathrm{~d} 130$ (Fla. 1957) (abolishing municipal immunity, holding that city could be liable for leaving jail unguarded and thus failing to protect prisoner against fire); Lewis v. City of Miami, 127 Fla. 426, 173 So. 150 (1937) (failing to segregate prisoner with venereal disease from other prisoners-exception to municipal immunity); McCorkell v. City of Northfield, 266 Minn. 267, 123 N.W.2d 367 (1963) (failure to provide custodian, leaving plaintiff vulnerable to fire-exception to municipal immunity); Dunham v. Village of Canisteo, 303 N.Y. 498, 104 N.E.2d 872 (1952) (failure to get medical assistance for prisoner when apparently required). Contra, Pelfrey's Adm'x v. City of Jackson, 291 Ky. 161, 163 S.W.2d 300 (1942) ; Stinnett v. City of Sherman, 43 S.W. 847 (Tex. Civ. App. 1897) (although policeman would have been liable, if joined, for failure to search a prisoner for weapons, city was not liable because of municipal immunity); Franklin v. Town of Richlands, 161 Va. 156, 170 S.E. 718 (1933) (municipal immunity).

As far as the cases granting recovery are amenable to explanation, they are not justified by the public benefit theory. Rather, it is thought that if the city chooses (albeit for the general welfare) to incarcerate people, it must provide for its prisoners as a matter of law. It is also intervention in its most striking form-prisoners have no choice but to rely on the city.

147 For a thorough discussion of police discretion, see W. LAFAvE, ARREST: The Decision to Take a Suspect into Custody (1965).

148 With this premise, under the fire protection analysis, liability would accrue whenever plaintiff could show that he was part of a large segment of the population that was denied police protection.

149 See cases collected in W. LAFAve, supra note 147, at 79-82.

150 Id. at 61-164 (passim).

151 Id. at 102 . 
adjudicatory decisions with implicit value judgments as to whether the available means of the law ought to be invoked. ${ }^{152}$ Discussion is heated on the propriety of the latter type of discretion. Arguably, those decisions are better left to the courts or, at the very least, to prosecutors. ${ }^{153}$ But even if the purely adjudicatory discretion were eliminated, the necessity of judgment in allocating limited resources, and in evaluating consequences of alternative strategies would still stand..$^{154}$ It is confusion of the two types of discretion that leads to blanket characterizations of the police role as ministerial.

With awareness of the necessity of at least one type of discretion, it becomes clear that the discretion rests not only in the policy-making officials of the police department, but extends down to the patrolman as well. While a fireman most often acts only under orders of his chief, the patrolman, like his superior, is a repository of discretion. ${ }^{155}$ The policeman's job of keeping the peace can take an infinity of forms in a multitude of situations. Rather than being ordered to perform a specific task, the public benefit requires that the policeman be posted at the scene, where he will deal with the trouble in the way he sees fit. ${ }^{156}$

The crucial issue is whether the discretion ought to be reviewed in an action for damages against the individual or city, rather than through other, institutional channels. ${ }^{157}$ It will be remembered that the primary policy behind insulation of official conduct is the possible dampening effect review will have on enthusiasm that ought to be encouraged. In the fire case, the concern would be that when faced with alternate courses of action $A$ (to act) and $W$ (to withhold), with $W$ strategically preferable in the circumstances, the fire chief will be deterred from course $W$ by his fear of liability. The harm is only

152 As part of a policy of non-enforcement of certain laws, see id. at 83 ; as a feeling that the criminal process would be inappropriate in certain cases, see id. at 125; or as a practice of less stringent enforcement for intra-minority group offenses, see id. at 110 .

153 Goldstein, supra note 145 , at 543.

154 Cf. W. LAFAve, supra note 147, at 71 n.32. The above discussion focuses on discretion whether to arrest. A type of judgment related to allocation of resources is the means to be used to effectuate the arrest. In some cases this approaches value judgment. For instance, police officials might think that the use of deadly force necessary to stop looting would in itself be a greater evil than allowing the looting to continue. Although this decision is more than the allocation of resources and clearly an evaluative judgment, it is not one which could be left to prosecutor or court.

155 Remington, Editor's Foreword, in W. LAFAvE, supra note 147, at xvi:

Nor have judges and lawyers been sufficiently aware of the nature of the police function, which in many respects is more like that of an important administrative agency than it is like the job of the fireman with whom the policeman is often compared.

156 It is conceivable that a policeman would be ordered to do a specific act, not requiring discretion. In that case, there is no reason why the anaylsis for the fireman's refusal would not apply. However, it is unlikely that a riot situation would give rise to such an order, where, though not "causing" the riot, its violation would affect a large group, rather than an individual.

157 See notes 127-28 supra and accompanying text. 
that he will not choose $W ; A$ is not inherently bad. With police, the case against liability for non-action is significantly stronger. Law and policy generally favor $W$ over $A$, on the premise that over-zealous police activity is undesirable and that the criminal process should not be invoked indiscriminately. When the patrolman chooses $A$, the law imposes liability for false arrest if he did not have the requisite quantum of probable cause or liability for use of excessive force in making an arrest. Given the choice between $A$ and $W$, the danger of liability for not acting is not only that he will decline to take $W$, but that he will choose $A$ too readily, frustrating the policy against overactive use of the arrest power. If police are not given broad discretion when the decision is made not to arrest, the net effect is to encourage the officer to be less careful in invoking the criminal process.

In sum then, if one posits the existence but unreviewability in damage actions of police discretion not to act, it would provide a ready explanation for the case law. Most of the cases can be categorized as involving the two types of discretion, legislative and administrative, ${ }^{158}$ so that the city is not a guarantor that no citizen will suffer an injury which the police could have prevented. ${ }^{159}$ In a number of instances, no liability was imposed even where policemen were at the scene of the injury and took no steps to prevent it ${ }^{160}$ - consistent with the proposition that discretionary power pervades the entire force.

Even if plaintiff were to surmount the above obstacles-that is, if the conscious denial of police protection is held to be actionable ${ }^{161}$ he still must prove that the denial did in fact cause his injury. This in most cases will be an insuperable task. ${ }^{162}$ But, more important, at this

158 See text accompanying notes 102, 108 supra.

159 Campbell's Adm'x v. City Council of Montgomery, 53 Ala. 527 (1875) (although asked, city failed to stop firing of powder in street); City of Lafayette v. Timberlake, 88 Ind. 330 (1882) (city failed to prevent unlawful use of streetsplaintiff beaten); King v. City of New York, 3 Misc. 2d 241, 152 N.Y.S.2d 110 (Sup. Ct. 1956) (city failed to have policeman at picket line, despite knowledge of previous violence); Little v. City of Madison, 49 Wis. 605, 6 N.W. 249 (1880) (failure to prevent wild animal show in street).

160 Adamczyck v. Zambelli, 25 Ill. App. 2d 121, 166 N.E.2d 93 (1960) (police failure to stop unlawful use of fireworks in parade, even though officers were on duty there); Murrain v. Wilson Line, Inc., 270 App. Div. 372, 59 N.Y.S.2d 750 (1946), aff'd 296 N.Y. 845, 72 N.E.2d 29 (1947) (injuries from crowd on public pier, where police were present).

161 This requires positing: a) that the decision was not within the bounds of any kind of permissible discretion; b) that for policeman there should be no defense of unreasonable risk of harm or that under the facts the defense does not apply. $C f$. note 87 supra.

162 Suppose the following situations:

1. It is alleged that by not suppressing a riot in its early stages, the police allowed it to assume massive proportions, resulting in injury to plaintiff. In view of the demonstrated high volatility of ghetto areas that do in fact explode-in spite of concerted police effort-a court would be unlikely to be persuaded that the police could have stopped it. Cf. Note, Riot-Insurance, 77 YaLE L.J. 541, 551 (1968). The difficulty of proof to one side, plaintiff could not surmount the bar imposed by court recog- 
point it becomes clear that if plaintiffs can prove causation, the city is potentially liable for the totality of riot damage. ${ }^{163}$ Whether or not that result is desirable, it generally goes against the predisposition of the common law, absent statutory authority, to stay its hand in this area. $^{164}$

\section{Restitution : by statute}

In any case, present liability for general riot damage is purely statutory. ${ }^{165}$ There are now indemnification statutes in twenty states, ${ }^{166}$

nition of the political nature of the resource decisions which created the explosive climate. See text accompanying note 69 sipra.

2 . It is alleged that police consciously and arbitrarily failed to prevent looting, of which they had actual knowledge. Again, the persistence of booty hunters in last summer's riots, notwithstanding the danger, evidences the difficulty of proving the assertion that the police would have been successful. It could be argued, however, that in light of the duty to prevent crime, see note 153 supra and accompanying text, if the police act on their determination that allowing looting to continue is the most rational strategem, they must pay with municipal liability for the privilege to circumvent their duty. Cf. Vincent v. Lake Erie Transp. Co., 109 Minn. 456, 124 N.W. 221 (1910). The result of such liability may be to deter police from the more humane response. 163 This would be more true in example (1) than in example (2) of note 162 supra.

164 See text accompanying notes 4468 supra.

165 See note 44 sipra. For studies of municipal liability statutes covering mob damage, see Antieau, Statutory Expansion of Municipal Tort Liability, 4 ST. Lours U.L.J. 351, 378 (1957) ; Jaffee \& Dubin, Trends in Municipal Liability: Riot Damages No. 532, at 282, in Ins. L.J. (May, 1967) ; Sengstock, Mob Action: Who Shall Pay the Price?, 44 J. URBaA L. 407 (1967); Note, Compensation for Victims of Urban Riots, 68 CoLum. L. REv. 57 (1968); Legislation, Liability of the Municipality for Mob Violence, 6 Ford. L. Rev. 270 (1937); Note, Communal Liability for Mob Violence, 49 HARV. L. REv. 1362 (1936).

168 Conn. Gen. Stat. Ann. \$7-108 (1958) (municipality); Kan, Stat. AnN. \$\$ 12-203, -204 (Supp. 1967) (city); Ky. Rev. STat. \$ 411.100 (1963) (city); Me. Rev. Stat. Ans. tit. 17, §3354 (1964) (city); Md. ANN. Code art. 82, §\$ 1-3 (1965) (city); Mass. AnN. Laws ch. 269, §8 (Supp. 1966) (city); Mrnn. Stat. ANN. \$373.28 (1966) (county); Mo. ANn. STAT. $\$ 537.140-.160$ (1949) (city); Mont. Rev. Code Ann. \$11-1503 (city), §94-5314 (1947); Neb. Rev. Stat. ch. 23, $\$ \$ 1001-09$ (1943) (county); N.H. REv. Stat. ANN. chs. 31:53-:55 (1955) (city); N.J. Stat. ANN. \$\$ 2A:48:1-:9 (1952) (municipality); N.Y. GEN. MUN. LAW § 71 (McKinney 1965) (city); OHTo REv. CODE ANN. $\$ \$ 3761.01-10$ (Page 1954) (county); N.C. Gen. Stat. \$ 162.23 (1952) (county); PA. Stat. AnN. tit. 16, $\$ \$ 11821-26$ (1956) (county); id. tit. 18, $\$ 3765$ (1963) (county); R.I. GEN. LAwS ANN. \$ 45-15-13 (1957) (city); S.C. CODE ANN. \$\$ 16-103 to -108 (1962) (county); W. VA. Code ANN. \$61-6-12 (1966) (county); WIs. Stat. ANn. \$66-091 (1965) (city).

These statutes were held constitutional in Sturges v. City of Chicago, 222 U.S. 313 (1911). Most of the states which presently have such liability created it in the nineteenth century. (Kan. 1862; Md. 1835; Mass. 1839; Mo. 1881; Mont. 1895; N.H. 1854; N.J. 1877; N.Y. 1855; Pa.: Philadelphia 1841, Allegheny 1849, Northampton 1863; R.I. 1896; S.C. 1871 ; Wis. 1863.)

Illinois, Law of July 28, 1961, \& 25-3 [1961] Laws of I11. 2032, repealed, Act 815, 1967 I11. Legis. Serv. 1486 (counties) and Laws of 1965, $\$ 1$ [1965] Laws of I11. 2968, repealed, Act 1283, 1967 Ill. Legis. Serv. 2347 (municipalities); California, Law of April 25, 1949, ch. 81, \$\$ 50140-45 [1949] Cal. Laws 259, repealed, Law of July 15, 1963, ch. 1681, \$17 [1963] Cal. Laws 3286; Louisiana, LA. REv. STAt. \$33:5065 (1950), repealed, Law of July 15, 1966, No. 458, \&1 [1966] La. Acts 9750, recently have repealed their indemnity statutes. New York's statute has remained in the state of suspension created by N.Y. UNConsol. LAws \$9193 (McKinney 1961). See Note, Municipal Tort Liability, 50 Corsell L.Q. 699 (1965). These developments have been labeled "the trend away from municipal liability." Note, Compensation for Victims of Urban Riots, 68 CortuM. L. REv. 57, 75 (1968). 
all of which place liability for mob damage on the local government, city or county. ${ }^{167}$ These statutes apply to the entire state, except in Missouri, ${ }^{188}$ which only makes cities over a certain size liable, and in Pennsylvania, which only applies the statute in three counties. ${ }^{169}$

The statutes are of many different types, with little uniformity among them. ${ }^{170}$ All states require that the damage result from mob action. Some statutes do not define "mob," 171 relying on the common law definition, while others merely state the minimum number of people who must be involved..$^{172}$

Connecticut, ${ }^{173}$ Kansas ${ }^{174}$ and Wisconsin ${ }^{175}$ are the only states which do not distinguish between riot damage to person and to property. Illustrative is the Connecticut statute, which reads:

107 Furthermore, five states make city officials personally liable for neglect to suppress after proper notice has been given. MoNT. Rev. Code ANN. \$ 94-5314 (1947); N.Y. GEN. Mun. Law \$71 (McKinney 1965); Pa. Stat. Ann. tit 16, §11822 (1956); W. VA. Code AnN. §61-6-12 (1966); WIS. Stat. Ann. §66-091 (1965).

168 Mo. Rev. Stat. \$ 537.140 (1949) (5000 population).

169 Pa. Stat. AnN. tit. 16, $\$ 11821-26$ (1956) (Allegheny (Pittsburgh) (1849), Northampton (1863) and Philadelphia counties (1840)).

170 Some consistency does appear, however, in the uniformly liberal court decisions as to who is a proper plaintiff. Thus, courts have allowed suits by a corporation, Spring Valley Coal Co. v. Spring Valley, 65 Ill. App. 571 (1895); a labor union, Butte Miners' Union v. City of Butte, 58 Mont. 391, 194 P. 149 (1920); a municipal corporation suing a county, Kensington v. Philadelphia County, $13 \mathrm{~Pa} .76$ (1850); and by a person neither a citizen nor a resident, Williams v. City of New Orleans, $74 \mathrm{Ia} 507$ (1871). Furthermore, at least where property damage is involved, the plaintiff need not be an owner to have standing to sue. Orr v. City of New York, 64 Barb. 106 (N.Y. Sup. Ct. 1872) (mortgagee) ; Loomis v. Oneida County, 6 Lans. 269 (N.Y. Sup. Ct. 1872) (tenants-in-common) ; Greer v. New York City, 3 Robertson Super. Ct. 406 (N.Y. 1865) (life tenants); Burgis v. Philadelphia County, 169 Pa. Super. 23, 82 A.2d 561 (1951) (bailees); Onslow v. Smith, 3 Doug1. 348, 99 Eng. Rep. 690 (K.B. 1784) (trustees).

171 Conn. Gen. Stat. AnN. §7-108 (1958) ; Ky. Rev. Stat. \$ 411.100 (1963); MD. Ann. Cone art. 82, $\$ 1-3$ (1965); N.J. STAt. ANn. $\$ \$ 2 A: 48: 1-: 9$ (1952); Mass. Ann. Laws ch. $269 \$ 8$ (Supp. 1966); Mo. Ann. Stat. $\$ \$ 537.140-160$ (1949) ; Mont. Rev. Code Ann. \$\$ 11-1503, 94-5314 (1947); N.H. Rev. Stat. AnN. chs. 31:53-:55 (1955); N.Y. Gen. Mun. LAw \$71 (McKinney 1965); WIs. STAT. ANN. \$66-091 (1965).

See Yalenezian v. City of Boston, 238 Mass. 538, 131 N.E. 220 (1921) ; Feinstein v. City of New York, 157 Misc. 157, 283 N.Y.S. 335 (Mun. Ct. 1935).

172 For example, Maine provides for twelve or more persons if armed, thirty if unarmed, ME. Rev. Stat. ANN. tit. 17, 3355 (1961); Kansas ten or more persons, Kan. Stat. AnN. \$12-204 (Supp. 1967); and Massachusetts at least five, Mass. ANn. Laws ch. 269, §8 (Supp. 1966). And four of the states whose statutes are really only "lynch laws" define a mob in terms of vigilante activities. NEB. REV. Stat. ch. 23, § 1001 (1965); N.C. Gen. Stat. \$162.23 (1952); OHio REv. Code AnN. $\$ 3761.01$ (Page 1954); W. VA. CoDE ANN. \$61-6-12 (1966). The fifth state with this type of lynch law is Minnesota. Minn. Stat. AnN. \$373.28 (1966).

The West Virginia statute, for example, reads:

Any collection of individuals, five or more in number, assembled for the unlawful purpose of offering violence to the person or property of anyone supposed to have been guilty of a violation of the law, or for the purpose of exercising correctional or regulative powers over any person or persons by violence, and without lawful authority, shall be regarded and designated as a "mob" or "riotous assembly."

173 Conn. Gen. Stat. Ann. \$ 7-108 (1958).

174 Kan. Gen. Stat. AnN. \$ $12-203$ (Supp. 1967).

175 WIs. Stat. ANN. § 66-091 (1965). 
Each city and borough shall be liable for all injuries to person or property, including injuries causing death, when such injuries are caused by an act of violence of any person or persons while a member of, or acting in concert with any mob, riotous assembly or assembly or persons engaged in disturbing the public peace.

Other states' legislation is limited either to property damage, ${ }^{178}$ to personal injury ${ }^{177}$ or to full coverage for property damage and coverage of personal injury only when a result of lynching. ${ }^{178}$ The five statutes covering only personal injury are originally anti-lynch laws ${ }^{179}$ and might not seem applicable in riot situations. They have, in fact, never been used for riot injuries. However, Minnesota's statute defines "lynching" as any killing of a human being "by act or procurement of a mob," 180 and could easily be construed to cover death caused by riot. Other statutes are said to apply only where a mob offers violence to persons supposed to have been guilty of a violation of the law, or where the mob exercises correctional or regulative powers over any persons; ${ }^{181}$ although all riots would not be covered, at least the case of a white mob stopping a Negro demonstration by force should be compensable. ${ }^{182}$ Those laws providing full coverage for property damage and only partial coverage for personal injury employ this type of "lynch law." 183

$176 \mathrm{Ky}$. Stat. AnN. $\$ 411.100$ (1963) ; Me. Rev. Stat. AnN. tit. 17, §3354 (1964); Mo. Ans. Code art. 82, \$1 (1965); MAss. AnN. Laws ch. 269, \$8 (Supp. 1966); Mo. Rev. Stat. § 537.140 (1949); Mont. Rev. Code AnN. \$11-1503 (1947); N.F. Rev. Stat. AnN. ch. $31: 53$ (1955); N.Y. Gen. Mun. Laws \&71 (McKinney 1965); R.I. GEN. LAws ANN. \$45-15-13 (1957).

177 Minn. Stat. ANn. \$373.28 (1966) (\$7500); Neb. Rev. Stat. ch. 23, § 1002 (1943) ( $\$ 1000)$; N.C. GEN. STAT. $\$ 162.23$ (1952) (recovery only for death of prisoner at hands of mob breaking into jail) ; OHro Rev. Code ANN. \$3761.04 (Page 1954) ( $\$ 5000)$; W. VA. CODE ANN. $\$ 61-6-12$ (1966) ( $\$ 5000)$

178 N.J. STAt. Ann. tit. 2A:48:1-9 (1952) ( $\$ 5000$ personal injury); PA. Stat. ANN. tit. 16, $\$ 11821-26(1956)$; id. tit. $18, \S 3765$ (1963) ( $\$ 25,000)$; S.C. CoDE ANN. $\$ \$ 16-103$ to -108 (1962).

179 See note 172 supra.

180 Minn. Stat. AnN. § 373.28 (1966).

181 Brocato, Liability of Local Govermental Subdivision Under Mob Violence Statutes for Injuries and Damage to Persons or Property, 14 LoCAL Governament L. Service LetTER No. 8, at 2 (1964). See, e.g., Hailey v. City of Newark, 22 N.J. Misc. 139, 36 A.2d 210 (Essex County C.P. 1944).

182 The now repealed Illinois law required a purpose of "collective or community interest" by the mob. A prima facie case was made out under the statute with allegations that a white mob tried to prevent Negroes from moving into a white neighborhood. Slaton v. City of Chicago, 8 Ill. App. 2d 47, 130 N.E.2d 205 (1955), noted in 54 MicH. L. REv. 1184 (1956).

183 See note 178 supra. 
Extent of recovery also varies from state to state. ${ }^{184}$ And in Connecticut, ${ }^{185}$ Kansas, ${ }^{186}$ Kentucky ${ }^{187}$ and Maryland, ${ }^{188}$ recovery is conditioned on negligence ${ }^{189}$ by the municipal authorities in prevention or protection. ${ }^{100}$

There is a minimum damage requirement of $\$ 50$ in order to recover under the statutes of Maine, ${ }^{191}$ Massachusetts ${ }^{192}$ and Rhode Island. ${ }^{193}$ Judicial interpretation of indemnification statutes has narrowed the scope of recovery even more in some states. The statutes covering property damage state that the property must be destroyed or injured, ${ }^{194}$ or that there must be destruction of property ${ }^{195}$ or injuries to property. ${ }^{196}$ When goods are looted by rioters, they are normally deemed destroyed, injured or damaged within the meaning of these

184 The statutes of Maine, ME. Rev. Stat. ANN. ch. 17, $\$ 3354$ (1964); Massachusetts, Mass. Ann. LAws ch. 269, $\$ 8$ (Supp. 1966); and Rhode Island, R.I. GeN. LAws ANN. \$45-15-13 (1957), indemnify only for three-quarters of the value of the property destroyed.

185 Conn. Gen. Stat. Ann. §7-108 (1958).

186 Kan. Stat. Ann. \$12-203 (Supp. 1967).

$187 \mathrm{Ky}$. Rev. Stat. ANN. $\$ 411.100$ (1963).

188 MD. ANN. CODE art. 82, $\$ 3$ (1965).

${ }^{189}$ Other statutes may be silent as to the fault requirement, but courts interpret the law as imposing absolute liability for mob damage to property. See, e.g., Northern Assurance Co. v. City of Milwaukee, 227 Wis. 124, 277 N.W. 149 (1938).

Recovery is never allowed if the plaintiff incited or abetted the riot. Palmer v. City of Concord, 48 N.H. 211 (1868); Underhill v. City of Manchester, 45 N.H. 214 (1864) ; Paladino v. Board of Supervisors, 54 App. Div. 337 (Sup. Ct. 1888). Some states have "notice" requirements. KY. REv. Stat. \$411.100 (1963); Mo. Ann. Code art. 82, \$2 (1965); N.H. Rev. Stat. Ann. ch. $31: 54$ (1955); N.J. Stat. AnN. §2A :48:3 (1952) ; N.Y. GEN. Mun. LAW \$71 (McKinney 1965); PA. Stat. ANN. tit. 16, §11822 (1956); S.C. CoDE ANN. \$\$16-103, -108 (1962); WIS. STAT. ANN. $\$ 66-091$ (1965). But, in New York, the city is held to constructive notice of the violence when it knows of riots in plaintiff's vicinity. Feinstein v. City of New York, 157 Misc. 157, 283 N.Y.S. 335 (Mun. Ct. 1935). Notice has been held not necessary if useless to prevent damage. Schiellen v. Board of Supervisors, 43 Barb. 490 (N.Y. Sup. Ct. 1865).

Finally, notice to the city of intent to sue is a mandatory requirement in New York. Goldberg v. Westchester County, 199 Misc. 859, 104 N.Y.S.2d 291 (Sup. Ct. 1951). The New York statute requires suit to be brought within three months. N.Y. Gen. Mun. Law \$71 (McKinney 1965).

190 Thus, the Connecticut law only indemnifies if the authorities "have not exercised reasonable care or diligence in the prevention or suppression of such mob, riotous assembly or assembly engaged in disturbing the public peace." CoNN. GEN. STAT. ANN. \$7-108 (1958). The statutes of Kentucky, Kansas and Maryland are similar, Ky. Rev. Stat. \$411.100 (1963); Kan. Stat. ANN. \$12-203 (Supp. 1967); MD. ANN. CODE art. 82, \$\$2-3 (1965), allowing recovery only if there was foreknowledge of the danger, time to prevent it and the ability to prevent it.

101 Me. Rev. Stat. Ann. tit. 17, § 3354 (1964).

192 Mass. Ann. Laws ch. 269, $\$ 8$ (Supp. 1966).

193 R.I. GEN. LAws ANN. §45-15-13 (1957).

194 Mass. Ann. Laws ch. 269, § \& (Supp. 1966); Mo. Rev. Stat. $\$ 537.140$ (1949); N.H. Rev. Stat. Ann. ch. $31: 53$ (1955); N.J. Stat. AnN. tit. $2 A: 48: 1$ (1952) ; R.I. GEN. Laws ANN. §45-15-13 (1957).

195 Kan. Stat. Ann. ch. 12-203 (Supp. 1967); Pa. Stat. Ann. tit. 16, §11821 (1956) ; S.C. CoDE ANN. \$ 16-107 (1962).

196 Conn. Gen. Stat. Ann. \& 7-108 (1958) ; Mont. Rev. Code Ans. tit. 11-1503 (1947) ; WIs. Stat. ANN. \$ 66-091 (1965). 
statutes. ${ }^{197}$ But courts in Rhode Island and Massachusetts have ruled that looting is not covered by their laws because nothing has been "destroyed or injured." 188 Finally, although a student note has argued that at least some intangible damages might legitimately be held compensable by the courts under existing statutes, ${ }^{199}$ the history of the statutes ${ }^{200}$ and the cases ${ }^{201}$ litigated thereunder leave little chance that the argument will prevail. ${ }^{202}$

197 City of Baltimore v. Poultney, 25 Md. 107 (1886); Sarles v. City of New York, 47 Barb. 447 (N.Y. Sup. Ct. 1886) ; Solomon v. City of Kingston, 31 App. Div. 562 (1881), aff'd, 96 N.Y. 651 (1884); Burgis v. County of Philadelphia, $169 \mathrm{~Pa}$. Super. 23, 82 A.2d 561 (1951); Febock v. Jefferson County, 219 Wis. 154, 262 N.W. 588 (1935).

198 Yalenezian v. City of Boston, 238 Mass. 538, 131 N.E. 220 (1921) ; Goldman v. Forcier, 68 R.I. 291, 27 A.2d 340 (1942).

199 Note, Compensation for Victims of Urban Riots, 68 Cor.uM. L. REv. 57, 71-72 (1968) [hereinafter cited as Compensation]. The argument made is that there are only two cases on the subject, Wells Fargo \& Co. v. Mayor of Jersey City, 207 F. 871 (D.N.J. 1913), aff'd, 219 F. 699 (3d Cir. 1915), cert. denied, 239 U.S. 650 (1916); and Palmer v. City of Concord, 48 N.H. 211 (1868), and they conflict. After stressing the reality and importance of business losses, the Note suggests that the cases can be rationalized as extremes at opposite ends of a spectrum and suggests a middle ground between allowing all claims for lost profits and none at all. Intangible damages are to be recoverable when accompanied by physical damage to property. Judicial precedent for such a rule can be found in the law of torts, where recovery for emotional distress was allowed only when it resulted from an act also causing physical injury. The final result would be that businesses in the heart of the riot area would be compensated in full for their losses, but claims from outlying businesses for lost profits would not be accepted.

200 The American statutes were modeled after the English Riot Act of 1714. 1 Geo. 1, c. 5, \&6 (1714). Wells Fargo \& Co. v. Mayor of Jersey City, 207 F. at 876; Note, Municipal Liability for Riot Damage, 81 HARv. L. Rev. 653 (1968) [hereinafter cited as Municipal Liability]. This statute reads in terms of "any such church or chapel, or any such building for religious worship, or any such dwelling-house, barn, stable, or other out-house" being "demolished" or "pulled down." That is, not only was tangible property the sole subject of this law, but it was not even clear that it covered theft of tangible property. To say that the American statutes are modeled after this law, and then to say the courts should interpret these statutes so as to partially cover business interruption losses would seem to be inconsistent.

201 The Wells Fargo court was directly confronted with the issue of business loss and refused to allow recovery therefor. The court pointed out that by ejusdem generis only physical property is covered by the statute. It also noted that the English Riot Act was the prototype of the American laws and it clearly did not cover intangible losses. The conclusion of the court was that such a serious alteration in the liability of the municipality would occur if intangible losses were compensable that it would not be proper for a court to so interpret the statute.

Further support may be found in Weir v. County of Allegheny, $95 \mathrm{~Pa} .413,417$ (1880). Although the issue in the lower court was whether interest on damages should be allowed, the court, in affirming the disallowance of the interest, stated that the statute covered only property actually destroyed, and not injuries in the nature of suspension of business.

The single case supporting the contrary position is Palmer v. City of Concord, 48 N.H. 211 (1868). That case is meagre support for drastic judicial modification of the existing law, since the supporting statement is dictum in a case where mob action injured only the one plaintiff and which, according to Wells Fargo, $207 \mathrm{~F}$. at 881, may never have resulted in a legal judgment.

202 The Note appears to operate on a basic assumption that rejuvenation of riottorn areas by private capital is the main goal to be achieved. Compensation, supra note 199, at 57-58. From this premise flows the urge to find a peg upon which the judiciary can hang indemnification for business losses. However desirable this result, 
Given the existence of these statutes, what is their justification? The most important objective is to spread the burden of injury once a riot has occurred. The government, on any level, is the better riskbearer; it is in the interest of society to assure those injured during a riot a quick recovery, so that the community as a whole has the means to reestablish itself. ${ }^{203}$

\section{Although government in general clearly is the better risk-bearer} than is an individual, the question of why the state has chosen to place the burden upon the municipal or county level is not answered by such a conclusion. ${ }^{204}$ Of the several governments chargeable, the city has seen its inherently narrowest tax base narrowed still further by the departure of the middle class and industry from the city, making it

the history of the statutes and the cases under them do not support it. See notes 201-202 supra.

More important, though, what would be the result of this suggested scope of compensation? First, the extra cost occasioned by liability for intangible damage would be staggering to a municipality. And how far into the future may a business project its loss in profits? Another crucial factor would be the effect on police conduct. The closing of bars, gun shops, and liquor stores is normal procedure in a riot. But might the city be reluctant to close these businesses if it will be liable as a result? The efforts of the city to minimize damage might be postponed. Moreover, are the businesses most likely to be closed-bars and gun shops-of a type which the city ought to be overly concerned with re-opening to stimulate the rehabilitation of the area? Curfews would raise the same questions. Conversely, the balance of letting the riot run its course to lessen the cost in human lives versus immediate repression to lower the cost in property might be tipped in favor of quick repression to save the immense liability for business interruption which would result if the riot continued more than a short period of time. Is consideration of such a factor proper? Last, such a theory would result in the municipality being liable for losses occurring perhaps far removed from the city in which the riot occurred. This seems to violate both the local nature of the responsibility at the foundation of the statutes and the principle of rehabilitating the devastated area. Under the theory of the Note, the $\$ 300$ physical damage of the $W$ ells Fargo case itself would mean a recovery of $\$ 43,300$, because of losses resulting from mob interference with the passage of plaintiff's wagons. Is all such damage properly put on the municipality? Clearly not.

203 A highly interesting discussion and partial justification of existing mob violence statutes in terms of a societal choice in cost and resource allocation may be found in Municipal Liability, supra note 200, at 654-56.

204 The current experimentation with, and exhaustive writing about, programs to compensate victims of violent crimes may provide some parallel insight into this issue. California, CAL. Gov't Code $\$ \S 13960-66$ (West Supp. 1967), and New York, N.Y. ExEc. LAw $\$ \$ 620-35$ (McKinney Supp. 1967) have enacted such laws. Both limit recovery to personal injury, and would appear to be operative during riots, although the New York statute provides for a permissive reduction in award if the victim contributed to his injury. Id. $\$ 631, \llbracket 5 . C f$. The Wall Street J., Jan. 17, 1966, at 14, col. 6 . Both designate the state as the responsible level of government.

Apparently, there has been no serious consideration of placing liability on the county or municipality, although some federal legislation has been proposed. See Geis, State Compensation to Victims of Violent Crime, in THE PRESIDENT's ConrMIISSION ON LAW ENFORCEMENT AND ADMTNISTRATION OF JUSTICE, TASK ForCE REpORT: CrIMIE AND ITS IMIPACT-AN Assessinent 157, 171-72 (1967). Possibly, this "oversight" is historically traceable to the invariable and exclusive comparison of victim indemnification with workmen's compensation. See id. at $161,163,171$. Philadelphia and New York City at one time considered municipal compensation, but concluded that the state was the more appropriate indemnifier, id. at 172, apparently, at least in Philadelphia, in part because of fear of financial burden. See Phila. Inquirer, Feb. 24, 1966, at 33, col. 1. 
least able to afford to be insurer. The reason it nevertheless bears the burden lies in the nineteenth century roots ${ }^{205}$ of the statutes.

One explanation for these statutes lies in the theory that the state has created the municipal corporation and in exchange has exacted from it the performance of the state's responsibility to preserve law and order in the community. This duty and obligation thus entrusted to the local subordinate government is by this enactment emphasized and enforced by imposing upon the local community absolute liability for property losses resulting from the violence of such public tumults. ${ }^{206}$ Conversely, local government is to be compelled, through the threat of liability, to prevent riots. The end to be accomplished is not merely compensation for loss, but prevention of loss with compulsory compensation as the incentive means. ${ }^{207}$

The continuing vitality, not to say the original basis in fact, ${ }^{208}$ of this reason for locating government liability in the municipal corporation, has been seriously questioned. ${ }^{209}$ The threat of financial loss will neither compel nor enable municipalities to control riots effectively. The problem of control is inextricably bound up in the problems of cause, which determine the likelihood, extent and severity of the riot. The statute's only deterrent effect ${ }^{210}$ is on control, as it is clear that it is ineffective to reach the widespread, long term social problems involved. These problems are far from exclusively traceable to local sources. And even directed at the narrowest level of improvement of "control"-police activity-it is clear that today's urban riots are often of such a magnitude as to be beyond the capacity of the local police-however efficient-to prevent extensive damage once the violence erupts. Indeed, if fear of the financial drain encourages control on the local level at all, once the riot has begun, it will be to produce a bias in favor of a strategy less solicitous of human life and limb and more repressive than might otherwise be warranted. ${ }^{211}$

205 See note 166 supra.

206 City of Chicago v. Sturges, 222 U.S. 313, 323 (1911) (dictum) ; see Louisiana ex rel. Folsom v. Mayor of New Orleans, 109 U.S. 285, 287 (1883) ; Pennsylvania Co. v. City of Chicago, 81 F. 317 (N.D. I1l. 1897) ; Anderson v. City of Chicago, 313 I11. App. 616, 40 N.E.2d 601 (1942); Allegheny County v. Gibson's Son \& Co., 90 Pa. 397 (1879).

207 Underhill v. Manchester, 45 N.H. 214, 221 (1864); Note, Communal Liability for Mob Violence, 49 HARv. L. Rev. 1362 (1936).

208 See Allegheny County v. Gibson's Son \& Co., 90 Pa. 397, 419-20 (1879).

209 Antieau, Statutory Expansion of Municipal Tort Liability, 4 ST. Lours U.L.J. $351,383(1957)$.

210 This may be less true in genuinely small cities and towns, where conditions are far more similar to those obtaining when the statutes were originally passed in the nineteenth century than are conditions in the modern metropolis.

211 Compare the 1964 Philadelphia strategy, N.Y. Times, Aug. 30, 1964, at 76, col. 1 (police under strict orders not to use tear gas or revolvers unless under severe attack), with the 1967 Newark approach, N.Y. Times, July 14, 1967, at 34, col. 2 (police instructed to fire when placed in jeopardy and use more drastic action). But $c f$. N.Y. Times, Feb. 18, 1968, $\S 1$, at 63 , col. 3, suggesting that in the political climate, the punitive approach could prevail regardless of any artificially induced bias.

It has been suggested that although no further incentive than the destruction itself is necessary to an effective control program, the presence of the statute might inhibit 
The statutes may also be explained on the basis of their deterrent effect on the citizens of the municipality. It has been said that the statutes have

the tendency to deter the lawlessness, since the sufferer must be compensated by a tax burden which will fall upon all property, including that of the evil doers as members of the community. It is likewise calculated to stimulate the exertions of the indifferent and the law abiding to avoid the falling of a burden which they must share with the lawless. ${ }^{212}$

Current history, however, teaches that such liability is no deterrent to the rioters and does not encourage citizens to control riots. Uncontrolled riot damage has occurred in cities which have indemnification statutes-Philadelphia and Newark-and also in cities which do not-Los Angeles and Detroit. If any analytical approach is warranted, it is clear that (1) rioters have normally been ghetto residents with low incomes who, as non-owners, are not affected by a tax levy; (2) non-rioting citizens in the area who are supposed to be encouraged to control the riot are also ghetto residents similarly unaffected by tax levy; (3) citizens whether from within or without the ghetto are afraid to act against a mob, feeling it is the responsibility of the police and not of the citizenry to control riots.

The demise of any coercive function of indemnification statutes cannot sweep the compensatory need into the same grave. Arguments that exsiting methods of private insurance are sufficient without any government aid to guarantee effective recovery are not supportable.

an official policy allowing the riot to burn itself out while concentrating totally on preventing its spread, as suggested by the 1967 Cambridge, Md. riot discussed at notes 70-74 supra and accompanying text. Municipal Liability, supra note 200 , at 654 .

A case for the continuing viability of the deterrent aspect of these compensation statutes is made in Note, Riot Instrance, 77 YALE L.J. 541 (1968). Apparently, liability generates a "general deterrence pressure" which acts on a "specific "category" of persons, i.e., persons or governmental entities who are in a position to prevent riots," id. at 547 n. 46, 557, to encourage "law enforcement agency coordination and consolidation [apparently across urban-suburban lines, $i d$. at 555], the proficiency of police training in riot-control techniques, and the quality of antiriot planning." Id. at 557 n.111. Although paying lip service as well to an (apparently) assumed concomitant impetus to "community effort to eliminate the serious and longstanding grievances which might lead to violence if neglected too long," id. at 554, the Note seems to have slipped inarticulately into a totally repressive approach to deterrence in proposing its model statutory solution: absolute liability statutes in the state or locality, whose fiscal integrity is protected by federal riot insurance; premiums chargeable to the state or locality and calculated variably on "the past riot record of the area, and other criteria reflecting the willingness of these entities to prevent riot violence." Id. at 557.

212 City of Chicago v. Sturges, 222 U.S. 313, 323-24 (1911). See also Louisiana ex rel. Folsom v. Mayor of New Orleans, 109 U.S. 285, 287-88 (1883) ; Butte Miners' Union v. City of Butte, 58 Mont. 391, 400, 194 P. 149, 150 (1920); Clark Thread Co. v. Board of Chosen Freeholders, 54 N.J.L. 265, 23 A. 820 (1892); Darlington v. City of N.Y., 31 N.Y. 164 (1865); County of Allegheny v. Gibson's Son \& Co., 90 $\mathrm{Pa} 397$ (1879); Legislation, Liability of the Municipality for Mob Violente, 6 Ford. L. REV. 270,273 (1937). 
When California repealed its municipal liability law in $1963,{ }^{213}$ it was stated in explanation that the statutes are unnecessary because "the risk of property loss from mob or riot activity is now spread through standard provisions of insurance policies." 214 What the California Commission neglected to realize is that not everyone in riot-prone areas can afford adequate, or indeed any, insurance; that insurance companies can cancel policies in anticipation of violence, or decline to insure at all in high-risk areas; ${ }^{215}$ and that insurance companies are much more likely to pay claims quickly if they in turn will be indemnified by the government. ${ }^{216}$ Indemnity statutes are needed for their continually vital remedial effect on the non-marginal, nonindividual societal loss occasioned by the riots.

That municipal efficiency and citizen responsibility will not be engendered by local liability does not argue that liability should not be imposed on the municipal corporation. Rather, it suggests that the proper focus for political solution to the problem of which level of government should pay for riot damage is the degree of taxing power and the ease of absorption in the tax base.

\section{RESTITUTION : by private insurance}

More than two-thirds of the states do not have any municipal liability for damage to property; in those states, the only indemnification available by right is through private insurance. Core coverage in most contracts to insure property is the Standard Fire Insurance Policy (S.F.I.P.), ${ }^{217}$ which constitutes the required minimum of included causes of fire loss, against which every fire insurance company must, under law, insure. ${ }^{218}$ Increased ambit of fire coverage, as well

213 Law of July 15, 1963, ch. 1681, \$ 17 [1963] Cal. Laws 3286.

214 Cat. Law Revision Comm'n, Recommendations Relating to Sovereign IMMUNITY 818 (1963)

215 Furthermore, because the riots have become widespread, insurance companies are less likely to cover communities which they had insured in the past. Indeed, during the week of August 18,1967, the Philadelphia Public Housing Authority was notified that all its insurance was being cancelled. The Authority then started receiving bids from other companies to reinsure its $\$ 110$ million worth of housing. Estimates put the probable premium price at many times the old rate for the same coverage. Phila. Inquirer, Aug. 19, 1967, at 7, cols. 2-6.

Also, "a Mayor Tate administration source said the City was checking reports of widespread cancellation of fire insurance in poverty areas throughout the city." Phila. Inquirer, Aug. 19, 1967, at 1, col. 2.

216 See text accompanying notes $267-270$ infra.

217 The S.F.I.P. is the 1943 New York form, see text accompanying note 233 infra, and is set out in $4 \mathrm{G}$. RICHARDS, LAW OF INSURANCE 1951, app. A, (5th ed. W. Freedman 1952) [hereinafter cited as RICHARDS], and in N.Y. INS. LAw § 168(6) (McKinney 1966). This 165 -line policy will be cited to by line whenever it is quoted. 218 The use of a standard policy, including its provisions and type, is, in general, made obligatory by the statute upon all insurance corporations, and in some states a penalty is imposed for violating the act . . .

3 RICHARDS $\$ 497$, at 1591. See, e.g., N.Y. INS. LAw §168(2) (McKinney 1966): No policy or contract of fire insurance shall be made, issued or delivered by any insurer or by any agent or representative thereof, on any property 
as extension of insurance to such perils as looting, theft, vandalism, explosion, business interruption and other non-fire loss by riot, is usually effected by way of additional endorsement to the basic S.F.I.P. ${ }^{219}$ The most important standard endorsement of added perils, the Extended Coverage Endorsement, "is generally an integral part of the fire insurance policy and is usually sold as a unit together with fire coverage." 220 The combined fire and extended coverage policy covers most tangible ${ }^{221}$ property loss. ${ }^{222}$ Like the policy to which it is appended, however, this endorsement is controlled by the exclusion

in this state, unless it shall conform as to all provisions, stipulations, agreements and conditions, with such form of policy.

The New York scheme has the standard policy in the body of the statute. N.Y. Ins. LAw $\$ 168(6)$ (McKinney 1966). CuRRENT ANNotations of THE 1943 New York Standard FIRE Insurance Policy 3-4 (1966) [hereinafter cited as ANNOTATIONS] indicates that 28 states give similar statutory mandates for the use of the S.F.I.P. In the remaining states, administrative supervision has led to the use of some form of the standard policy. See, e.g., 73 ILL. STAT. ANN. \$755 (1965) (certain provisions required to be submitted to and approved by the Director of Insurance) ; 3 RICHARDS $\$ 497$, at 144 n.10 (Supp. 1967).

Variations in the standard form apparently do not affect the terms of the exclusionary clause. See ANNOTATIONS 4-10. For an example of a required fire insurance policy that varies from the S.F.I.P. form, see MrNN. STAT. ANN. \$65.011 (Supp. 1967).

219 The standard policy states that "[a]ny other peril to be insured against or subject of insurance to be covered in this policy shall be by endorsement in writing hereon or added hereto." [11. 38-41].

4 RICEARDS 1953, app. A. For examples of commonly used extended coverage endorsements, see E. Patterson, Cases and Materials on the law of Insurance 764-75, app. H (3d ed. 1955).

Seventeen stzies allow changes in the form of the S.F.I.P., under the supervision of the instirance commissioner, for multiple line coverage. ANNOTATIONS $\$ 13 \mathrm{~F}$. These are package policies, combining fire and other kinds of insurance, such as the extended coverage and vandalism-malicious mischief endorsements, or marine and casualty lines. But these expanded policies cannot be less favorable to the insured in r-gard to fire insurance than the coverage contained in the standard fire policy. See, e.g., N.Y. INs. LAw $\$ 168(7)$ (McKinney 1966):

Subject to approval of the superintendent, a multiple peril policy which combines insurance against the peril of fire with another kind or kinds of insurance . . . need not comply with the provisions of subsection six of this section, provided . . . such policy contains, with respect to the peril of fire, terms and provisions no less favorable to the insured than those contained in the standard fire policy. . . .

For rules on the issuance of endorsements, see N.Y. INs. LAw $\$ 169$ (McKinney 1966). 220 President's Nat'i Advisory Panel on INs. IN Riot-AfFected AReas, Meeting the Insurance Crisis of Our Cities 19 (1968) [hereinafter cited as INS. PANEL].

221 The conjunction of the Extended Coverage Endorsement with the standard fire policy does not extend the type of damage covered to indirect damages, e.g., business interruption, rent loss, food spoilage, etc. Separate insurance policies may be purchased to cover such indirect losses. See the discussion of business interruption damage in Compensation, supra note 199, at 63-4.

222 The Extended Coverage Endorsement covers "damages arising from windstorm, hail, explosion [which is usually defined to] also include riot, riot attending a strike, civil commotion, aircraft, vehicles, and smoke .... direct loss from pillage and looting occurring during and at the immediate place of a riot, riot attending a strike or civil commotion are included risks." INS. PANEL 19. The Panel also reported that

[a]bout 70 percent of insured Detroit and Newark riot losses were paid under fire and extended coverage contracts, according to a study by the 
of risk clause, ${ }^{223}$ and is thereby limited in scope unless otherwise extended.

Before 1873 , the terms of fire insurance policies, like all other contracts, were freely negotiable by the contracting parties. ${ }^{224}$ However, insurance companies issued such a variety of overly-technical forms, clogged with small print, that the uncertainty, ambiguity and consequent partial indemnity to the insured resulted in the enactment of the 1873 Massachusetts standardized fire policy, ${ }^{225}$ closely followed by the 1887 New York Standard Fire Policy, ${ }^{226}$ which achieved currency in 30 states within 25 years. ${ }^{227}$ A revision of the 1887 form resulted in the 1918 New York Standard Fire Policy ${ }^{228}$ which had been adopted, approved or in common use in 16 jurisdictions by 1932.229

Both the 1887 and 1918 New York standard policies excluded losses by "riot" and "civil commotion," as well as by "insurrection." 230 The lesser disturbance-the "riot" or "civil commotion" 231 -thus trig-

National Insurance Actuarial and Statistical Association.

Id. at 22. Recovery under core policy or endorsement, or a combination thereof, is permitted up to the face value of the policy only.

223 See note 237 infra.

2243 RICHARDS $\S 497$, at 1587-88.

$225 I d$. at 1588 .

228 Law of May 29, 1886, ch. 488, §§1-2, [1886] N.Y. Laws, authorized the Superintendent of Insurance to prepare a policy unless the New York Board of Fire Underwriters filed a form before the deadline. The Board filed, and the draft becarie the required form after Jan. 1, 1887. 3 RICHARDS $\$ 497$, at 1588-89. For the full policy, see E. Patterson, Cases and Materials on the Law of Insurance 786-92 (1st ed. 1932).

2273 RICHARDS $\$ 497$, at 1589 . In these states, the form was adopted either "by statutory enactment, ruling, or by usual practice or custom." Id.

228 Law of May 14, 1917, ch. 440, §3, [1917] N.Y. Laws, enacted into law the revised policy drawn up by the National Association of Insurance Commissioners, which had begun work on the updating at the instance of the New York legislature five years earlier.

229 PATTERSON, supra note 226 , at 796.

230 Id at 789 (1887) ; 4 RicHands 2007, app. D (1918). The 1918 policy excluded from liability any loss:

caused directly or indirectly by invasion, insurrection, riot, civil war or commotion, or military or usurped power, or by order of any civil authority; or by theft; . . . or (unless fire ensues, and, in that event, for damage by fire only) by explosion of any kind, or lightning; . . . . [11. 31-34].

231 "Riot" and "civil commotion" were not subjected to case law factual variations which would have served to define one term in contradistinction to the other, primarily because both were excluded risks, and the distinction between them unnecessary. 'Thus, in most cases, the minimum disturbance which reached exclusionary proportions was either litigated as "riot," see Spring Garden Ins. Co. v. Imperial Tobacco Co., $132 \mathrm{Ky} .7,116 \mathrm{~S} . \mathrm{W} .234$ (1909), or as "riot or civil commotion," see, e.g., Kirshenbaum v. Massachusetts Bonding \& Ins. Co., 107 Neb. 368, 186 N.W. 325 (1922). Compare the common definition of riot:

[a]n assembly of individuals who commit a lawful or unlawful act in a violent or tumultuous manner to the terror or disturbance of others.

International Wire Works v. Hanover Fire Ins. Co., 230 Wis. 72, 74, 283 N.W. 292, 293 (1939); 5 J. Appleman, Insurance Law AND Practice, $\$ 3111$, at 250 (1941) [hereinafter cited as APPLEMAN] with the definition of "riot" and "civil commotion" in tandem:

Riot and civil commotion import occasional local or temporary outbreaks of unlawful violence, which, though temporarily destructive, do not rise to the 
gered the exclusionary clause, making the distinction between "riot" and "non-riot" the focus of litigation. ${ }^{232}$

A 1939 revision of the 1918 form by the National Association of Insurance Commissioners was enacted, after numerous changes, by the New York legislature in 1943. ${ }^{233}$ The 1943 S.F.I.P. simplified the insurance contract, while generally broadening coverage, ${ }^{234}$ and has been put to use in all of the states and the District of Columbia. ${ }^{235}$ Conspicuously, ${ }^{236}$ "riot" and "civil commotion" were omitted from the revamped exclusionary clause while "insurrection" was re-

\begin{abstract}
proportions of organized rebellion against the government. . . The words "riot or civil commotion" as used in the policy in suit will be given their popular meaning, and be held to imply the wild or irregular action or tumultuous conduct on the part of three or more persons assembled together for the common purpose of doing an unlawful act.
\end{abstract}

Kirshenbaum, sipra, 107 Neb. at 372, 186 N.W. at 326. See also 5 Applearan, \$ 3111, at 250 .

The only case found in which the difference between "riot" and "civil commotion" was relevant to decision is Hartford Fire Ins. Co. v. War Eagle Coal Co., $295 \mathrm{~F}$. 663 (4th Cir. 1924). The UMW had been attempting to unionize in Mingo County, and various forms of violence were current. Plaintiff's buildings were insured under a clizuse excepting liability "caused directly or indirectly by invasion, insurrection, civil war or commotion." Id. at 664. Apparently, by stipulation of the parties, the issue betore the court was whether the "loss or damage sustained by plaintiff was caused either directly or indirectly by riot or civil commotion," id., even though the exclusion clause $\mathrm{n}$.rde no mention of "riot." The court, finding that the five conspirators who had secretly dynamited the building at 1:00 A.M., had made the plan the day before, held :

[t] he fire yas not caused by riot, for there was no tumult nor disturbances nor even a demonstration before the fire.

Id. at 665 . The court therefore considered the question of civil commotion, beginning by citing the definition as:

An uprising among a mass of people which occasions a serious and prolonged disturbance and an infraction of civil order, not attaining the status of war or an armed insurrection. A civil commotion requires the wild or irregular action of many persons assembled together.

Id. The court continued:

We think there can be little doubt that civil commotion arose from time to time in some portions of Mingo county. It seems to us the evidence raised a serious question whether the conspiracy and destruction . . . was a consequence of lawlessness in sections of the county where there had been civil commotion, or was due to the independent initiative of the five conspirators Id. However, the "serious question" was raised by the evidence, and therefore the trial judge's decision in favor of plaintiff was held to be conclusive on the appellate court. Id.

232 The cases and issues are collected in 5 ApPLEMAN $\$ 3111 \& \mathrm{nn} .1-21$ (1941, Supp. 1967) ; 3 Richards $\$ 512$ \& nn. 8-14 (1952, Supp. 1967); cf. Annot., 121 A.I.R.' 250 (1939).

233 N.Y. INS. LAW § 168 (McKinney 1966).

234 See Comment, The New Standard Fire Insurance Policy in Nerv York, 42 Corusr. L. Rev. 1227 (1942) ; N.Y. Times, Feb. 28, 1943, § 5, at 6, col. 2.

235 See note 218 supra.

238 The characterization has origin in 3 RICHARDS \$ 512, at 1663 . However, reform efforts had focused on other aspects of the 1918 form, including especially the "moral hazards clauses," see Goble, The Moral Hazard Clatuses of the Standard Fire Insurance Policy, 37 CoLum. L. Rev. 410, 414 (1937) ; Patterson, The Transfer of Insured Property in German and Amercian Law, 29 CoLum. L. Rev. 691 (1929); Comment, The New Standard Fire Insurance Policy in New York, silpra note 234, rather than on the excluded perils under discussion. 
tained. ${ }^{237}$ In a separate clause, fire damage caused by riot was explicitly alluded to by the express limitation on insurer liability for damage from "explosion or riot, unless fire ensue, and in that event for loss by fire only." 238 The phrasing of this clause implies that rather than adding to the meaning of the excluded perils clause, its purpose was to make clear that only the incremental damage due to fire caused by riot or explosion is covered, while non-fire damage attributable to other riot or explosion consequences is not. ${ }^{239}$ When construed together, the two clauses do not create an inclusion-exclusion dichotomy corresponding to riot-insurrection which would hold what is not included as a riot, excluded as an insurrection. ${ }^{240}$

Rather, under the S.F.I.P., the lawlessness in the city streets must amount to the new minimum ${ }^{241}$ of excluded risk-"insurrection"-as

237 The exclusionary clause in the 1943 S.F.I.P. reads :

This company shall not be liable for loss by fire or other perils insured against in this policy caused, directly or indirectly by: (a) enemy attack by armed forces, including action taken by military, naval or air forces in resisting an actual or immediately impending enemy attack; (b) invasion; (c) insurrection; (d) rebellion; (e) revolution; $(f)$ civil war; $(g)$ usurped power; (h) order of any civil authority except actions of destruction at the time of and for the purpose of preventing the spread of fire, providing that such fire did not originate from any of the perils excluded by this policy:-

(i) neglect of the insured to use all reasonable means to save and preserve the property at and after a loss, or when the property is endangered by cire in neighboring premises; $(j)$ nor shall this company be liable for loss by theft [11. 12-24].

4. RICEARDS 1952, app. A (emphasis added).

238 In context, the clause reads:

Conditions suspending intsurance. Unless otherwise provided in writing added hereto this Company shall not be liable for loss occurring

(a) while the hazard is increased by any means within the control or knowledge of the insured; or

(b) while a described building, whether intended for occupancy by owner or tenant, is vacant or unoccupied beyond a period of sixty consecutive days; or

(c) as a result of explosion or riot, unless fire ensue, and in that event for loss by fire only [11. 28-37].

Id. 1952-3, app. A.

239 See 3 RICHARdS $\$ 527$. Compare the 1943 wording of this clause, note 238, supra, with its origins in the 1887 and 1918 policies, note 230 supra, in which liability for incremental damage by fire from explosion and lightning, rather than explosion and riot is described, and the Extended Coverage Endorsement, note 222 supra.

${ }_{240}$ In Comment, Insurance Protection against Civil Demonstrations, 7 B.C. IND. \& CoM. L. REv, 706 (1965), assumption of riot-insurrection as the critical dichotomous parameter leads the unwary authors to spin off a proposed test in which lawlessness aimed at society or against civil authority, because "public" in nature, results in exclusion under the term "insurrection," while destruction aimed only at citizens or their private property, because "private" in nature, results in inclusion as a "riot." Id. at 708. The Watts disorder of 1964 would accordingly be an "insurrection," because of a surmised causal link with the repeal of the Rumford Fair Housing Act, inadequate education and job discrimination to ghetto residents. Id. at 711-12. See further discussion at note 248 infra and accompanying text.

241 The degrees of violence of domestic origin enumerated in the exclusionary clause, note 237 supra, are "(c) insurrection; (d) rebellion; (e) revolution; (f) civil war," an order which approximates increasing magnitude:

As the insurrection develops into an affair of greater magnitude, so that the insurgents come into de facto control of a definite region of the country, the insurrection may be spoken of as a "rebellion". If the insurrection or rebellion 
construed in the context of its surviving the former riot-civil commotion-insurrection continuum alone. ${ }^{242}$ Accordingly, in the leading case of Home Insurance Co. v. Davila, ${ }^{243}$ which involved fire damage from the 1950 uprising staged by Nationalist Party patriots in Puerto Rico, Judge Magruder pointed out:

Sometimes the word "insurrection" is used to characterize an outbreak or disturbance more limited in its objective than the forcible overthrow of the government-for instance, where the civil authority in a community has been defied and temporarily rendered impotent in consequence of a labor struggle. . . But we are dealing here with the meaning of "insurrection" in an insurance policy which expressly covers fires set in consequence of a "riot"; and which contains no exclusion of fires caused by a "civil commotion" . . . . ${ }^{244}$

\section{The result of these considerations is that}

an intention to create a series of local disturbances, or "civil commotions" . . . to embarrass and discredit the . . . government, to dramatize the ... prepared [ness] to die for

proceeds to the attainment of its objective, viz., the overthrow of the old constituted government and the establishment of a new one in its place, then the movement, retroactively, will be dignified by the characterization of a "revolution".

Home Ins. Co. v. Davila, 212 F.2d 731, 736 (1st Cir. 1954). See also Werster's New International Dictionary 2075 (2d ed. 1956) (definition of "rebellion").

"Order of any civil authority" and "usurped power" are also domestic, but of a different order from the foregoing. One excludes destruction resulting from orders of a constituted authority on the one side and of an unconstituted authority on the other. For a discussion of destruction by order of civil authority, see Compensation, sitpra note 199 , at 62 , and especially note 48 , which suggests that an issue arising thereunder is unlikely in the riot context.

242 See N.Y. Times, Feb. 28, 1943, $\S 5$, at 6, col. 2, stating that "[e]xtension of coverage in the revision includes .. . loss by fire following a riot or civil commotion . . "The article also indicates that some authorities construed "civil commotion" to include labor disturbances involving the police. Id.

It would seem that many labor disputes have a "public purpose" as that phrase is used in Comment, Insurance Protection against Civil Demonstrations, note 240 supra, and would constitute the excluded risk- "insurrection"-under the theory there propounded.

243212 F.2d 731 (1st Cir. 1954). The fire policy clauses there were identical to the S.F.I.P. clauses quoted at notes 237, 238 supra. Id. at 732-33.

$244 I d$. at 736. The clause in apposition to "civil commotion" reads, "a category which insurers sometimes include in a clause of excepted perils." Id. at 736. Judge Magruder apparently was unaware in 1954 that the S.F.I.P. had been, according to 3 RICHARDs $\$ 497$, at 1590 \& n.10, in required use by 1951 in 44 of the then 48 states, as well as Hawaii, Alaska and the District of Columbia, including New York, the originator of the S.F.I.P. and the home of the Home Insurance Co. Because Judge Magruder relied on the fact that insurers of prior years had indeed excluded "civil commotion" damage from coverage does not derogate from the force of his argument as regards the S.F.I.P., under which an insurer could not make "civil commotion" an excepted peril. In the face of the change itself, it is irrelevant whether the legislature (or insurance commissioner) or the private insurer has excluded only "insurrection" damage from coverage. 
the ideal of freedom, for propaganda purposes to fire a shot "heard around the world . . . ." 245

though superadding a political direction to the wantonness ordinarily associated with riots, does 'not constitute an 'insurrection' within the meaning the [S.F.I.P.]." ${ }^{246}$ That state of exclusion is not achieved unless the additional objective "to overthrow the constituted government and to take possession of the inherent powers thereof" 247 is present.

It has been suggested that to define the "insurrection" exclusion along the embarass-overthrow lines outlined above would disserve the purpose of the exclusionary clause, which is designed to safeguard the insurer's solvency. ${ }^{248}$ Certainly, every excluded peril is a cushion against insolvency; ${ }^{249}$ but it is equally true that every potentially bankrupting peril is not excluded in order to protect solvency. Insurance would be a mockery if that were true. Moreover, it is not the insurer's self-interest which controls the construction of the exclusion clause,

245212 F.2d at 738.

$246 I d$.

$247 \mathrm{Id}$. at 736.

248 Comment, Insurance Protection against Civil Demonstrations, note 240, supra, at 709-11. Apparently, the exclusion clause is supposed to distinguish between states of high and low probability of extensive property loss.

A more specific analysis of the insurance risk might suggest that the probability of bankruptcy from catastrophic loss will vary differently with (a) whether the same company has underwritten a number of properties simultaneously destroyed by fire during a riot, and (b) whether any one property among all the ghetto properties will be ravaged in a riot. The insurance company on its own can minimize its aggregate loss under the former variable by calculating the number of properties it can afford to lose simultaneously and reducing its insurance load in the high potential disturbance area accordingly. Certainly judicial removal of the damage from the ambit of liability would also minimize this risk. But the blunt tool of judicial construction cannot do service for more sensitive utilization of the minimization by spreading of risk principal reflected in such legislative and administrative alternatives as assigned risk, see Note, Riot Insurance, 77 YALE L.J. 541, 546-47 (1968); urban area (FAIR) plans, see id. at 545; INs. PANEL, supra note 220, at 87-95; pooling for problem risks, see id. at 95-99; and federal reinsurance, see id. at 99-105; which all take into account a balance of social need for private insurance of core city property with the need for insurer solvency. Moreover, even a modification of the S.F.I.P. to permit companies to insure separately for riot damage, see Compensation, supra note 199 , at $64-$ a plan which would achieve essential parity of insurer risk protection with the suggested public-private gloss on the exclusion clause-would require companies to insure against the full peril of "insurrection." The result would be unavailability of riot insurance, even though the likelihood that any one building in a ghetto area will burn at some point during the life of its insurance contract may not increase proportionately to an increase in the actuarial likelihood of a riot occurring and encompassing it. The significance of that single uninsurable risk-loss by riot-may be sufficient to moot the need for any insurance by driving enterprises out of the ghetto.

249 Cf. Pape v. Home Ins. Co., 139 F.2d 231, 236-37 (2d Cir. 1943) (L. Hand, J., dissenting) (policy insuring against loss by "Riot", "Civil War", "Civil Commotion" or "Military or Usurped Power" rationalized as protecting only against the lesser risks of "lawless violence" in contradistinction to "confiscation"); Boon v. Aetna Insurance Co., 40 Conn. 575, 584 (1874), rev'd on other grounds, 95 U.S. 117 (1877) ("riot, insurrection and civil commotion" characterized as "though temporarily destructive in their effects, did not rise to the proportions of organized rebellion against the government"). 
since it is the public interest which has dictated the compromise between protection of the insurer and protection of the insured ${ }^{250}$ and resulted in the minimum of coverage afforded under the Standard Fire Insurance Policy. Insurer solvency cannot dictate reconstruction of the legislative intention.

It is clear that under the standards enunciated in Davila, the summer riots do not amount to "insurrections" within the meaning of the exclusion clause. ${ }^{251}$ Neither the fact that "the civil authority [was] defied and temporarily rendered impotent," ${ }^{252}$ nor the political motivation of the provocateurs or mob leaders to embarrass the established government, ${ }^{253}$ can supply the intent "to overthrow and take possession" 254 of government which was at least arguably ascribable ${ }^{255}$ to the Puerto Rican Nationalist Party in Davila.

A variant on the insurrection exclusion issue may arise in the context of the municipal indemnity statutes. Those statutes exact liability from the municipality on a showing of damage variously described as resulting from riot, riotous or tumultuous assembly, mob action or assembly of persons engaged in disturbing the peace. ${ }^{256}$ "Riot" would seem to be the most extensive of the contemplated dis-

250 No rule of interpretation of an insurance contract is more firmly embedded than that which declares that where the language of the policy is without violence susceptible of two interpretations, one of which being that contended for by the insured, it should be most strongly construed against the insurer for the language is that of the insurer.

3 RICHARDS $\$ 397$, at 1314; see cases cited in id. $\$ 397$, at 17 n.6 (Supp. 1967). This rationale is not undercut when the language of a policy is mandated by law, because the insured comes to the printed form with his everyday understanding of language. See Insurance Co. of North America v. Rosenberg, 25 F.2d 635, 637 (2d Cir. 1928) ("This policy of insurance should be liberally construed so that the insured will be indemnified against loss, which the parties intended so to insure against." (emphasis added)).

251 The Michigan Insurance Commissioner at first called the Detroit insurance companies, asking whether they had made assurances that they would not defend on the insurrection exception, and received "No" for an answer. Conversation with David T. Walker, Esq., of Philadelphia, Aug. 14, 1967. The N.Y. Times, July 28, 1967 , at 10, col. 5, reported that "[i]t was indicated that some claims . . Would be contested .. because the riots had been termed "insurrections." "See Note, Riot Insturance, 77 YALE L.J. 541, $544 \mathrm{n} .25$ (1968). The INS. PANEL, note 220 supra, at 19 , however, could assert categorically by January, 1968, that "[i] nsurance companies have made no attempt to avoid paying claims arising from the recent disorders by calling them acts of insurrection."

252 See text accompanying note 244 supra.

$253 \mathrm{See}$ text accompanying note 245 supra.

254 See text accompanying note 247 supra.

255 The issue in Davila was framed in terms of the adequacy of the charge to the jury, because the issue of sufficiency of plaintiff's evidence was not preserved. 212 F.2d at 733, 735. The court held that a proper jury charge must indicate that once "a movement accompanied by action" to achieve the insurrection purpose is shown, $i d$. at 736 , the fact that the property damage occurs at "such an incipient stage of the insurrection ... [that no] rebel armed forces ... are actually engaged in military operations against an army of the constituted government which has taken the field against them," $i d$. at 737 , or that "reasonable men might conclude that this objective was not possible of accomplishment," id. at 738, is irrelevant to the necessary conclusion that loss was caused by "insurrection." 
turbances. Thus, in addition to insurrection, ${ }^{257}$ it is arguable that a disturbance which is more than a riot but less than an insurrection precludes liability where "riot" can be considered as quantitatively distinguishable in the continuum from riot through civil commotion to insurrection. It is not necessary to refute this extension of the insurance argument in terms by pointing to the technical history of the standard insurance policies and to their deployment of these words of art in the various excluded and included risk clauses. The history of the indemnity statutes clearly gives warrant to the use of an exclusive riot-insurrection dichotomy. ${ }^{258}$ Recalling the various deterrent func-

257 Cf. Harris v. York Mut. Ins. Co., 50 Pa. 341 (1865), where "loss by fire occasioned by mobs and riots" was the excluded risk. Damage to plaintiff's property from the flames of a bridge fired upon under order of a Union Army general under apprehension of an imminent Confederate attack was held compensable because it was caused by "much more than either a mob or a riot in the ordinary acceptation of these terms." Id. at 350 .

258 A parallel argument to that made in Comment, Insurance Protection against Civil Demonstrations, note 240 supra, can be put forward in the indemnity statute context: a narrow reading of "riot" will lessen the risk of bankrupting the municipality. Of course, given that the statutes have a coercive purpose, and absent the "innocent" insurer in the insurance context, the argument loses some of its force. Cf. County of Allegheny v. Gibson's Son \& Co., 90 Pa. 397, 412 (1879) (argument made and lost that indemnity statute was not intended to "apply to such unlooked for and exceptional circumstances" as interstate labor unrest). Yet, loss of continued fiscal integrity of the municipality to the call of deterrence is to throw out the baby with the bath water. Moreover, recent commentaries have suggested a similar concern for adequacy of local resources to indemnify for large scale destruction. Compare Note, Riot Insurance, 77 YALE L.J. 541, 554 (1968) ("The fragmentation of taxing authority between center city and suburban towns and counties makes it difficult, if not impossible, for the relevant municipal government to find the revenue to pay for the sudden and heavy damage produced by major riots.") with Municipal Liability, supra note 200, at 656 ("municipal liability may divert resources from other urgent uses ... . [rather] than ... levy increased taxes. ... [although riots] will not be regular occurrences . . . [and] bonds can spread the costs over an extended period.").

The number of cities affected by riot and the extent of damage sustained in the 1960 's have, however, distorted perspective on the original legislative awareness of such contingencies. When such statutes were passed in England and the United States, the politically acceptable level and flexibility of taxation in general, let alone by a municipality, was considerably lower than at present. The dollar in 1850 was the equivalent of about $\$ 6.00$ in 1960. Letter from Sherman Robinson, Tutor in Economics, Harvard University, March 7, 1968, on file in Biddle Law Library, Philadelphia, Penna. And the extent of the worst riot damage compensated under the statutes in the last century was not incomparable to that of the 1960's.

County of Allegheny v. Gibson's Son \& Co., supra, involved the 1877 Pittsburgh labor riots against the Pennsylvania R.R. The liability of Allegheny county, which had no "concentrated police force; . . . townships and boroughs [which were] disconnected municipalities, having no combined magistracy, no organized and consolidated constabulary, and no common head to govern and direct . . . "90 $\mathrm{Pa}$. at 412 , was for damage in the millions, $i d$. at 420 , and yet not even comparable to the prior London, Philadelphia and New York riots. Id. at 413.

[T] he "No Popery" riots of London, in June 1780 ... was the most extensive riot of which we have any record. For several days, the mob, numbering sixty thousand persons, had complete control of London. The authorities were paralyzed. The immediate cause of the tumult was the presentation of a petition by Lord George Gordon to Parliament for the repeal of Sir George Saville's Act for the relief of Catholics. The riot commenced on June $2 \mathrm{~d}$, and continued until June 8 th. It was not confined to the city of London, but spread throughout the kingdom. The whole city was in a state of anarchy. On the evening of June $6 \mathrm{th}$, thirty-six different 
tions of the statutes on the local level, at the point of insurrection and in the face of intent to overthrow [local] civil authority, deterrence through tax liability is either superfluous or meaningless. Short of insurrection, however, the participants in a civil disturbance are

a mob, and nothing more. It has never been held that the responsibility of a city or county for the violence of a mob depends upon its size or formidable character . . ..$^{259}$

It is rare that a mob is without a large body of sympathizers at its commencement. This is because its fury is generally directed against an unpopular object. In populous communities, especially in large cities, there are always antagonisms of race, religion, politics or social condition, which enable the demagogue to fan the fires of popular discontent, and incite the disorderly to acts of violence. It is because of this sympathetic feeling that mobs are often enabled to get the mastery, the fact being overlooked that a mob, when once aroused and maddened by success, becomes, like a wild beast, dangerous alike to friend and foe. ${ }^{260}$

If deterrence operates, it operates to dam the wellspring, not the river. Even if neither an insurer nor a municipality could defend under the insurrection exclusion because the mobs lacked Davila's "intent to overthrow," they nonetheless might be in a position to point to an action of the executive calling the civil disorders "insurrections." 261

fires were raging, caused by the mob. The famous prisons of the Fleet and King's Bench were fired, and the prisoners released; all the public buildings threatened; many private houses sacked ... More than four hundred and fifty persons were killed. It was only by the vigorous use of the military power that the mob was finally subdued. The courts of England held that the loss fell within the statute, and the respective hundreds were liable. Another instance is the Philadelphia riots of 1844. Here, again, the civil power was wholly inadequate to suppress the mob, and it was only put down at last by the stern use and display of the military arm. Said the late Judge King, in his charge to the grand jury: "Our city during these scenes of violence has exhibited the appearance of a town of war, instead of the pacific seat of science and literature, of commerce and the industrial arts." The amount of property destroyed was large, for all of which, the county was held liable . . . Later still, we have the draft riots of New York in 1863, when an entire army corps was withdrawn from the front, where it was sorely needed, to hold in check the rebellious elements of that city. In numerous cases the Court of Errors and Appeals held the city liable. . . . Some idea of the extent of the damages caused by the mob during this riot, may be inferred from the fact, that upon the argument of the case last cited, counsel representing the plaintiffs in nine hundred and fifty other cases were heard.

Id. at $417-18$.

$259 I d$. at 417.

$260 I d$. at 419.

261 In the 115 riot-racked cities in the summer of 1967 , see U.S. NEWS \& WoRLD Report, Aug. 28, 1967, at 49, only one civil disorder reported by national newspapers was characterized as an "insurrection." See, e.g., the story on Detroit in N.Y. Times, July 15, 1967, at 1, col. 7. See also Compensation, supra note 199, at 60 n.37. 
Under hoary precedent, ${ }^{262}$ executive proclamations of martial law and states of insurrection are not generally open to challenge.

There is little question that the executive declaration does not so conclude a court construing an insurance policy. ${ }^{263}$ The executive's decision to characterize a civil disorder in a particular manner may depend on the statutory mobilization of extraordinary powers triggered by use of the key word ${ }^{264}$ or, indeed, by purely political motives. ${ }^{265}$ When determining the propriety of the exercise of powers made available through the required form of declaration, the courts may well decline to interfere with the initial exercise of judgment on the ground that the executive might otherwise unwisely hesitate from fear of liabilities some future court might attach in reexamining his actions. On the other hand, when examining the character of a civil disorder to determine insurers' liability, courts can appropriately go behind the executive declaration because examination de novo will not affect the validity of any action enabled by the declaration. The executive should not take insurance considerations into account ${ }^{266}$ with the riot-control and political factors which are exclusively appropriate to choosing the best course of action, and the courts should not force him to do so by giving his invocation any independent weight. The same reasoning applies equally well to recovery under the municipal indemnity statutes.

An owner of property destroyed in the riots may fortuitously find himself in the enviable position of carrying insurance in a jurisdiction which also has an indemnity statute. If the Philadelphia experience is indicative, the battle of the insured against exclusion from policy

262 The line of cases includes Luther v. Borden, 48 U.S. (7 How.) 1 (1849) and Moyer v. Peabody, 212 U.S. 78 (1909); modifying the strict rule against judicial intervention are Ex parte Milligan, 71 U.S. (4 Wall) 2 (1866), and Sterling v. Constantin, 287 U.S. 378 (1932). See Note, Rule by Martial Laze in Indiana: The Scope of Executive Power, 31 Ind. L.J. 456, 462-63 (1956).

263 Indeed, it would be anamolous for the test of "insurrection" based on intent and the objectives of the participants, to be conclusively satisfied by an executive assertion of the existence of a riot. See Hartford Fire Ins. Co. v. War Eagle Coal Co., 295 F. 663 (4th Cir. 1924). In that case, although the Governor had declared a state of war, insurrection and riot in the county, the court nevertheless examined the surrounding facts in finding against the insurance company's claim of excluded risk. See also Compensation, supra note 199, at $61 \mathrm{nn} .43,44$.

264 See note 6 supra and accompanying text.

205 The evidentiary value of an executive determination of the existence of a riot or an insurrection may well be questioned. An executive who is responsible for the peace of the locality in which the disorder occurs must make an immediate decision; he has little time for reflection and is too close to the event for a properly disengaged analysis. In making his decision, he must apply a standard which reflects his responsibilities. Rather than fail to react with sufficient strength to quell an insurrection, it might seem better for one in his position to apply greater force than necessary to suppress a riot. A proper standard for insurance purposes should not be dependent upon such over-reactions of local officials.

286 N.Y. Times, July 30,1967 , § 1 , at 1 , col. 3, reported :

Governor Romney was reluctant to use the word "insurrection" in applying and writing for Federal troops because he felt this might invoke escape clauses in insurance policies and prevent hundreds of property owners from being reimbursed for their losses. 
coverage will give way to horsetrading and potential suit between the municipality and the insurance companies.

After the 1964 summer riot, the insurance companies met with the Assistant City Solicitor to discuss city indemnification of insurers for payments to policyholders. The city offered seventy-five cents on each dollar of insurance payments, threatening that it would otherwise defend against claims on the ground that the companies had no right of subrogation against Philadelphia. The insurance companies accepted the offer in an oral agreement which further stipulated Philadelphia's supervision of claims adjustments over $\$ 10,000 .^{267}$

Within 120 days after the riot, the insurance carriers paid up their policy obligations (in the form of loan receipts). Non-insured persons' claims against the city were negotiated to settlement with the city's adjuster, ${ }^{268}$ Payment in hand, ${ }^{269}$ however, both to the uninsured and to the companies had to await a 1966 allocation in the city budget of $\$ 1.2$ million for riot claims. ${ }^{270}$

The city's ability to bargain down indemnification of the carriers to 75 per cent apparently resulted from the murkiness of the law of subrogation in general, and its relation to the statutory liability in particular. After payment of the full policy amount, ${ }^{271}$ the insurer would ordinarily be "subrogated in a corresponding amount to the insured's right of action against any other person responsible for the loss." 272 The twin rationales for the equitable doctrine of subrogation were that while the tortfeasor should not go financially unpunished because the victim received insurance, neither should the victim be allowed simultaneous recovery from the tortfeasor, which would encourage loss, contrary to the principle that property insurance is "a contract of indemnity." By default, the victim's insurance company was awarded recovery from the responsible party. ${ }^{273}$ The first rationale

267 Telephone conversation with John M. McNally, Deputy City Solicitor of Philadelphia, on January 9, 1968.

$268 I d$.

269 Compare the requirements of PA. STAT. AnN. tit. 16, $\$ 11821$ (1956):

[T] he amount which shall be recovered in said action shall be paid out of the county treasury, on warrants drawn by the commissioners thereof, who are hereby required to draw the same as soon as said damages are finally fixed and ascertained.

270 Conversation with John M. McNally, supra note 267.

271 When the insurer does not pay the full amount of the loss, the insurer may be barred from maintaining an action against the tortfeasor. "This rule was designed to preclude the splitting up of a cause of action, thereby harrassing the tortfeasor to defend two suits for the same wrong." 2 RichaRDs $\$ 201$, at 693 .

On the other hand, the constructive trust created by a perfected right of subrogation, and payment by the tortfeasor to the insured, gives rise to conflicting measures of reimbursement to the insurer varying from (1) the sum of insurance payments and tortfeasor payments less actual loss through (2) the amount actually paid out by the insurer to (3) the amount of recovery by the insured against the tortfeasor. Id. $\S 198$, at $684-87$.

2726 ApPLEarAN $\$ 4051$, at 517.

273 See Atkinson, The Real Party in Interest Rule: A Plea for its Abolition, 32 N.Y.U.L. REv. 926, 942 (1957); Kimball \& Davis, The Extension of Insurance Subrogation, 60 MrCe. L. Rev. 841 (1962). 
can be criticized as anachronistic where the suit is successfully brought against the wrongdoer's insurer, the employer's carrier in a respondeat superior situation, or the government under tort claims acts, because the wrongdoer goes unpunished anyway. If reduced to reliance on the second rationale-unjust enrichment of the insured-the doctrine would call for blind adherence to windfall compensation to the insurer, without reconsidering the original equitable bases. ${ }^{274}$

With this background, the municipal liability statutes arguably make the city merely another wrongdoer against whom the insurer has a right of subrogation. ${ }^{275}$ The statutes create liability with a deterrent objective $^{270}$ common to the law of torts, although proof of fault is

\section{See 2 RICHARDS $\$ 183$, at 653-54:}

[S] ubrogation ... constitutes a valuable privilege bestowed upon insurance companies by courts long indifferent to the doctrine of true indemnity in their zeal to respect the literal language of such unilateral contracts of insurance. Courts have mouthed the utterances of astute insurance counsel that subrogation is necessary to preclude double recovery by the insured or any form of unjust enrichment gained from the prosecution of claims against both the insurer and the tortfeasor causing the loss or damage. But these same courts ... have again overlooked the axiom that it is equally unjust to preclude the insurer from suffering a loss which it had expressly agreed to assume as a risk in return for the payment of premiums. As Professor Patterson has so aptly commented: "Subrogation is a windfall to the insurer. It plays no part in rate schedules (or only a minor one), and no reduction is made in insuring interests . . . Even as to tortfeasors, it is arguable that since the insurer is paid to take the risk of negligent losses, it should not shift the loss to another."

But cf. Compensation, supra note 199, at $74 \mathrm{n} .144$ :

While it is true that subrogation recoveries play no part in the calculation of individual risks, insurance premiums are usually based upon a calculation of total losses, a figure considerably reduced by subrogation recoveries.

275 In Northern Assur. Co. v. City of Milwaukee, 227 Wis. 124, 277 N.W. 149 (1938), the court held that the insurer of a property owner who suffered damage resulting from a riot attending a strike could be subrogated against the city under Wisconsin's mob-violence statute, on the one sentence rationale that "Whatever actions survive are assignable." Id. at 127,277 N.W. at 151 .

The argument that the government should be treated no differently from an individual defendant was handled more thoroughly in litigation arising under the Federal Tort Claims Act. In United States v. Aetna Cas. \& Sur. Co., 338 U.S. 366 (1949), the government conceded that the insurer would have subrogation rights against the government upon payment to the insured if the Federal Tort Claims Act stood alone, for the Act stated:

[T] Une United States shall be liable in respect of such claims to the same claimants, in the same manner, and to the same extent as a private individual under like circumstances. . . .

28 U.S.C. $\$ 931$ (a) (1940), as ainended, 28 U.S.C. $\$ 2674$ (1964). The outcome, instead, turned on the effect on $\$ 931$ (a) of the anti-assignment statute, now 31 U.S.C. $\$ 203$ (1964). The mob-violence statutes, however, do not parallel the clear Congressional intent found by the Court in $\$ 931$ to allow such subrogation. 338 U.S. at 376-80.

But cf. Sun Indemnity Co. v. Board of Ed., 264 App. Div. 73, 34 N.Y.S.2d at 475, appeal denied, 264 App. Div. 873, 35 N.Y.S.2d 732, dismissed, 289 N.Y. 644, 44 N.E. $2 \mathrm{~d} 618$ (1942), where the insurer of a teacher-tortfeasor was held not to be subrogated against the city, which was bound by statute to indemnify the teacher for liability for negligence in the discharge of duties. The court reasoned that when the legislature altered the law to create liability in the city, the liability applied only to the beneficiary. "That right may not be extended by implication, or recourse to assignment or the principle of subrogation." 264 App. Div. at 74, 34 N.Y.S.2d at 476.

276 See text accompanying notes 206-07 supra. 
irrelevant to recovery in most states. ${ }^{277}$ Since it is unlikely that insurance could be had against this municipal liability, the classic first rationale of subrogation would be satisfied, the loss falling on the object of the law's deterrence. On the other hand, any deterrent force on the city operates through aggregate liability rather than by payment in each case of property loss. Responsibility for all of the riot damage is not a demonstrably greater deterrent than responsibility for the largescale uninsured loss standing alone, which past experience has shown to be considerable. The purpose of the statute being directed at stopping a riot before significant injury has occurred, the superadded liability for insured loss via subrogation is unnecessary.

Furthermore, the statutes have a clearly compensatory and riskspreading purpose which could easily be considered primary at this date. ${ }^{278}$ The carriers and the municipality are both indemnifiers, and as between the two-the one for profit, the other not for profit-the municipality has the greater equities. Indeed, the municipality is arguably ${ }^{279}$ a preferred insurer. ${ }^{280}$ If it pays a claimant before the carrier does, it could argue its own right to subrogation against the carrier. ${ }^{281}$

The insurer has some historical basis for asserting that the indemnity statute must be read in conjunction with the riot insurance required by the S.F.I.P. The 1943 Standard Form was adopted against an existing background of statutes dating from the nineteenth

277 The exceptions are Connecticut, Kansas, Kentucky and Maryland. See notes 185-88 supra.

278 See Muricipal Liability, supra note 200, at 653-54.

279 Cf. 6 Ford. L. REv. 270, 272 (1937).

280 An argument for contribution by the city would be open to the insurance company if the municipality could be considered an ordinary, non-preferred insurer. Liability on both city and carrier (through the S.F.I.P., if the insurer elects to underwrite in the area) for mob damage has origin in statute, and the two are co-insurers, each fully liable to the insured, but subject to the equitable right of contribution. 2 RICHARDS $\$ 175$, at 637. Moreover, the pro rata clause of the S.F.I.P.:

Pro Rata Liability. This Company shall not be liable for a greater proportion of any loss than the amount hereby insured shall bear to the whole insurance covering the property against the peril involved, whether collectible or not [11. 86-89].

4 RICHARDS 1954, app. A., would give the insurer a defense against paying more than its aliquot share of the riot loss, especially under the caveat "whether collectible or not" (which is absent in the Mass. S.F.I.P. and the Minn. S.F.I.P., Mass. ANN. Laws ch. 175, \$99, at 309 (1959); MinN. Stat. AnN. \$65.0111 (Supp. 1967)).

It is difficult to see, however, how equity would grant a cause of action for contribution against the city where it would not grant subrogation, on some theory of "the paying insurer ... hav[ing] paid a debt which is equally and concurrently due by the non-paying insurer. . . ." 2 RICHARDS $\$ 175$, at 637 . Furthermore, a pro rata clause cannot comprehend municipal indemnity "insurance" when the insurance statute provides:

If there are two or more policies upon the property, each shall contribute to the payment of the whole or partial loss in proportion to the amount specified. MLnN. Stat. AnN. \$65A.08(4) (Special Supp. 1967) (emphasis added).

281 For a similar sentiment, but a more pessimistic appraisal of the law of subrogation, see Compensation, supra note 199 , at 7475. 
century. ${ }^{282}$ However, the temporal sequence does not warrant assuming legislative determination (let alone that of an insurance commissioner ${ }^{283}$ ) to create a right of subrogation against the city, for which the pre-1943 insurer who excluded riot loss had no need. The insurance companies could only state that they (mistakenly) had presumed a subrogation right, and would not have been, and will not in the future be, as likely to underwrite in a riot-prone area. But this rough stimulus to insure in such areas would be a poor judicial substitute for the more comprehensive solution required.

More difficult to overcome is the technical argument that the property owner's right to assign his claim against the city ${ }^{284}$ includes such assignment to the insurer. Although an equitable right to subrogation cannot be perfected against the municipality, assignment of the claim in the insurance contract can.

The simple response to this line of reasoning is that if the claimant had insurance covering his loss, he had no further claim under the statute to assign, for the same reason that the insurers have no equitable subrogation rights. The difficulty here is that to construe the indemnity statutes as covering only net loss places a considerable strain upon their language. However, the assignment of claims clause in the S.F.I.P. is merely declaratory of existing principles of subrogation, ${ }^{285}$ and does not significantly alter the outlines of the equitable right; ${ }^{286}$ when the policy behind subrogation fails, effective assignment must also fail. ${ }^{287}$

A second and somewhat variant legalistic route around a holding that subrogation cannot be had against the city may be open under the doctrine of the loan receipt, first recognized judicially by Mr. Justice Brandeis in Luckenbach v. W. J. McCahan Sugar Refining Co. ${ }^{28 s}$ The loan receipt entails full payment under the policy,

282 See note 166 supra.

283 See note 218 supra.

284 See Agudo v. County of Monterey, 13 Cal. 2d 285, 89 P.2d 400 (1939).

285 The clause is entitled "Subrogation" and reads:

This Company may require from the insured an assignment of all right of recovery against any party for loss to the extent that payment therefor is made by this Company [11. 162-65].

4 RICBARDS 1555 , app. A. Indeed, 2 id. $\$ 183$, at $652-54$, treats the assignment of claims clause as identical to equitable subrogation.

286 See Yorkshire Ins. Co. v. United States, 171 F.2d 374, 375 (3d Cir. 1948), aff'd stb nom., United States v. Aetna Cas. \& Sur. Co., 338 U.S. 366 (1949) ("[S]ubrogation . . . is in the nature of an assignment by operation of law.").

It has been asserted that the clause is only meant as an insurance industry hedge against possible loss of subrogation through payment of claim without asserting a valid defense. Compensation, supra note 199, at 74. See also 6 Appleman \$ 4051, at 523-24, and cases cited therein.

287 Cf. United States v. Aetna Cas. \& Sur. Co., 338 U.S. 366 (1949). The government argued that the anti-assignment statute precluded subrogation by the insurer, The Court held that subrogation claims were carved out of the anti-assignment statute because they constituted an assignment at law. Id. at 376 . See also note 275 supra. 288248 U.S. 139 (1918). 
"repayable only in the event and to the extent that any net recovery is made . . . from . . . other parties, on account of loss or damage occasioned to property . . . ." 289

under an agreement giving the insurer the right to conduct any suit on behalf, but retaining the name, of the insured.290

The insurance policy in Luckenbach covered the shipper for loss of goods in transit, where the carrier was not legally responsible for the loss because of the unseaworthiness of the vessel. Carrier and insurer liability were thus entirely supplemental. The carrier had exacted an agreement from the policyholding shipper whereby any insurance payment made to the shipper would work as a setoff against the carrier's liability. On the one hand, if shipper's insurer made payment for loss for which the carrier and not the insurer were liable, it would lose any ordinarily subrogated claim against the carrier because, as subrogee, it could have no claim greater than the subrogating shipper. On the other hand, if the insurance company waited to pay on its policy until determination of carrier fault, the shipper would go uncompensated in the interim. The loan receipt was held not to constitute payment under the carrier-shipper contract, thus preserving the shipper's claim and, via the terms of the loan receipt, allowing the insurer to sue in the name of the insured.

Since Luckenbach, most jurisdictions have consistently approved the use of the loan receipt in cases in which the risk of defeat in fact of the insurer's contingent non-liability by prompt payment is nonexistent. ${ }^{201}$ Apparently, the reason for the indiscriminate extension of the doctrine is not in the preservation of claims of the insured to which the insurer can then be subrogated, but rather in the subterfuge of suit in the insured's name after payment to circumvent the real party in

$289 \mathrm{Id}$. at 147. Form PIC-326, on file in the Biddle Law Library of the University of Pennsylvania, was used by a major insurance group to settle its 1964 riot claims. Telephone conversation on Aug. 14, 1967, with an attorney for a major Philadelphia carrier, which has asked that its name be withheld. Efforts by the University of Pennsylvania Laze Review to obtain the form used by the General Adjustment Bureau, Inc., the adjustment agent for the Philadelphia companies settling the majority of claims arising out of the 1964 riots, were to no avail. Telephone conversation by the University of Pennsylvania Laze Revieze with Douglas Wilford, General Accident Bureau, Inc., March 6, 1968. The Pennsylvania Insurance Commissioner further advised that he exercised no control over settlement forms and, therefore, had none on file. Telephone conversation with David O. Maxwell, Commissioner, February 26, 1968. See also the loan receipt reproduced in 4 RrCHARDS 2272, app. DD.

290 [Insured] hereby appoint the agents of the said Company and their successors, severally, ..........agent(s) and attorney (s) in fact with irrevocable power to collect any such claim and to begin, prosecute, compromise or withdraw, in ......... name. . . .

Form PIC-326, supra note 289.

201 See, e.g., Watsontown Brick Co. v. Hercules Powder Co., 201 F. Supp. 343 (M.D. Pa. 1962) ; Boynton, The Myth of the "Loan Receipt" Revisited under Rule 17(a), 18 S.C.L. REv. 624, $628 \mathrm{nn}$. 15-16 (1966) and cases therein cited. 
interest statutes. ${ }^{292}$ The courts do not seem to want to force insurance companies to identify their interest before juries.

Thus, the right in the insurer created by the loan receipt is identical to that existing under equitable subrogation, except that the insurer may sue in the insured's name and the "loan" payment in and of itself does not defeat subrogation to an otherwise subsisting claim of the insured against the wrongdoer. The former has no application in the municipal indemnity situation, and the latter is no more than an alternative formulation of the issue already resolved against insurer subrogation. ${ }^{203}$

\section{CONCLUSION}

One point that emerges clearly from the analysis of subrogation is the need for legislative clarification of the relation of insurance to the mob-violence statutes. Certainly, the Philadelphia compromise was unsatisfactory: either the insurer should have been indemnified to the full extent of the statute, or taxpayer contribution entirely avoided, or partial indemnification of insurers integrated into some comprehensive plan.

Fortunately for the highly-regulated insurance area, state legislatures or the Congress may well react constructively to the spectre of total withdrawal of voluntary insurance from the ghetto. Although the moral imperative and economic intolerability of the present law is patent, insurance reform would seem to be the only important area in which initial steps can be taken. The other forms of restitution-and even emergency relief-suffer from an inherent ambivalence which redirects any tendency for constructive invention towards the creation and dissemination of anti-riot equipment. ${ }^{294}$
LEAR:
Rive your concealing continents, and cry
These dreadful summoners grace. I am a man More sinn'd against than sinning.
Close pent-up guilt,

King Lear, act III sc. ii.

292 Atkinson, The Real Party in Interest Rule: A Plea for its Abolition, 32 N.Y.U.L. REv. 926, 945 \& n.122 (1957); Boynton, sipra note 291, at 625.

293 The loan receipt has been attacked as contrary to the subrogation clause, see note 285 supra, which is supposed to limit assignment of rights of action to when payment has been made under the policy. Apparently, the "loan," see text accompanying notes 288-91 supra, was not considered "payment" in the ruling of Charles $R$. Howell, Comm'r of Banking \& Insurance for New Jersey, in Bulletin No. 11 (Official 67-3), Assignment of Subrogation Rights Against Municipality, Sept. 18, 1967, abstracted in N.Y.I.J., Sept. 19, 1967, at 1, col. 7-8. But cf. Condar Inv. Co. v. Pacific Coca-Cola Bottling Co., 211 F. Supp. 671 (D. Ore. 1962). However, the Bulletin is unclear to what extent the fact that the loan receipts were executed prior to any reimbursement whatsoever, including a "loan," affected the outcome.

294 See the logistical plans and arsenals set out in Wills, The Second Civil War, Esquire, March, 1968, at 71. 